\title{
Annual Radioactive Waste Tank Inspection Program - 1999
}

by

c. J. Moore

Westinghouse Savannah River Company

Savannah River Site

Aiken, South Carolina 29808

This paper was prepared in connection with work done under the above contract number with the U.S. Department of Energy. By acceptance of this paper, the publisher and/or recipient acknowledges the U.S. Government's right to retain a nonexclusive, royalty-free license in and to any copyright covering this paper, along with the right to reproduce and to authorize others to reproduce all or part of the copyrighted paper. 


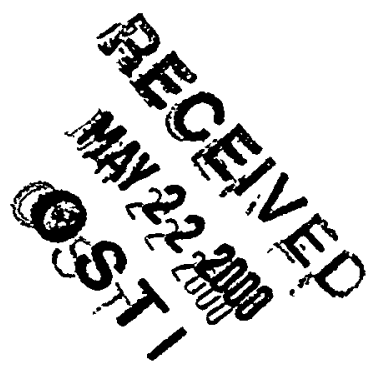

\section{Annual Radioactive Waste Tank Inspection Program - 1999(U)}

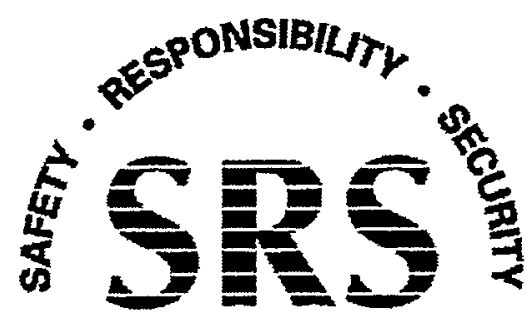

SAVANNAH RIVER SITE

Westinghouse Savannah River Company

Savannah River Site

Aiken, SC 29808

Prepared for the U.S. Department of Energy under Contract No. DE-AC09-96SR18500 


\section{DISCLAIMER}

This report was prepared as an account of work sponsored by an agency of the United States Government. Neither the United States Government nor any agency thereof, nor any of their employees, makes any warranty, express or implied, or assumes any legal liability or responsibility for the accuracy, completeness, or usefulness of any information, apparatus, product or process disclosed, or represents that its use would not infringe privately owned rights. Reference herein to any specific commercial product, process or service by trade name, trademark, manufacturer, or otherwise does not necessarily constitute or imply its endorsement, recommendation, or favoring by the United States Government or any agency thereof. The views and opinions of authors expressed herein do not necessarily state or reflect those of the United States Government or any agency thereof.

This report has been reproduced directly from the best available copy.

Available for sale to the public, in paper, from: U.S. Department of Commerce, National Technical Information Service, 5285 Port Royal Road, Springfield, VA 22161, phone: (800) 553-6847

fax: (703) 605-6900

email: orders@ntis.fedworld.gov

online ordering: http://www.ntis.gov/ordering.htm

Available electronically at http://www.doe.gov/bridge

Available for a processing fee to U.S. Department of Energy and its contractors, in paper, from: U.S. Department of Energy, Office of Scientific and Technical Information, P.O. Box 62, Oak Ridge, TN 37831-0062, phone: (865) 576-8401

fax: (865) 576-5728

email: reports@adonis.osti.gov

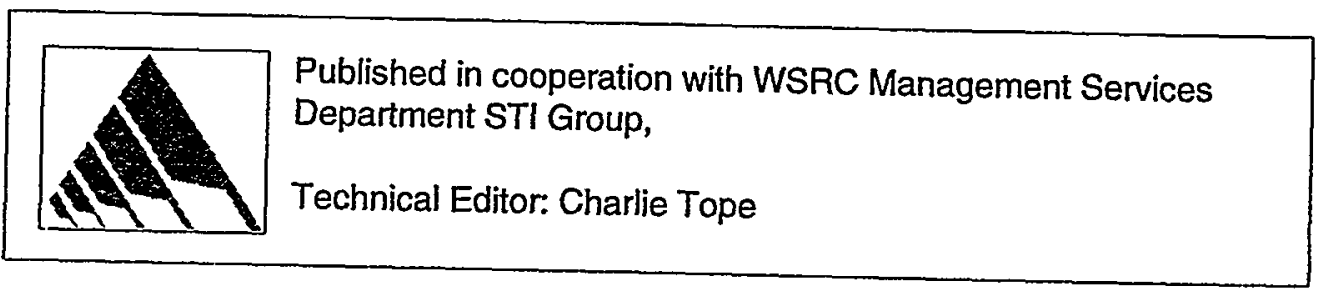




\section{DISCLAIMER}

Portions of this document may be illegible in electronic image products. Images are produced from the best available original document. 
WSRC-TR-2000-00067

Publication Date: May 2000

\title{
Annual Radioactive Waste Tank Inspection Program - 1999(U)
}

\author{
J. M. Mealing \\ C. J. Moore \\ R. R. Robbins \\ R. S. Waltz \\ W. R. West
}

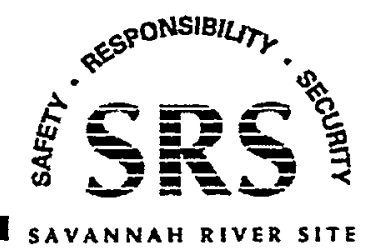


This page intentionally left blank. 


\section{Contents}

Acronyms and Abbreviations...........................................1

Introduction ........................................................................3

Summary ............................................................................

Inspection Program........................................................... 7

Background ........................................................................ 7

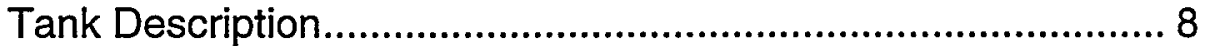

Inspection Methods ................................................................ 13

Program Implementation .................................................15

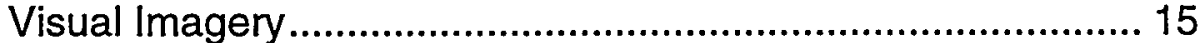

1999 Inspection Results ......................................................... 15

Summary of Inspection Results .............................................. 16

Appendix A-Waste Tanks at SRS .................................23

Appendix B-Summary of 1999 Inspections ..................25

\section{List of Figures}

1. Type I Waste Storage Tank ............................................. 8

2. Type II Waste Storage Tank .............................................. 9

3. Type IV Waste Storage Tank ............................................. 10

4. Type III Waste Storage Tank ........................................... 11 
This page intentionally left blank. 


\section{Acronyms and Abbreviations}

$\begin{array}{ll}\text { A } & \text { Annulus } \\ \text { ASME } & \text { American Society of Mechanical Engineers } \\ \text { BFV } & \text { Back Flush Valve } \\ \text { CCTV } & \text { Closed Circuit Television } \\ \text { CCWS } & \text { Chromate Cooling Water System } \\ \text { COP } & \text { Clean Out Port } \\ \text { CTS } & \text { Concentrate Transfer System } \\ \text { CSTE } & \text { Concentration Storage and Transfer Engineering } \\ \text { CWT } & \text { Concentrated Waste Tank } \\ \text { DB } & \text { Diversion Box } \\ \text { DOE-SR } & \text { Department of Energy-Savannah River } \\ \text { DP } & \text { Direct Photography } \\ \text { ERIP } & \text { Encasement Riser Inspection Port } \\ \text { ETF } & \text { Effluent Treatment Facility } \\ \text { EVAP } & \text { Evaporator } \\ \text { F } & \text { Fahrenheit } \\ \text { GDL } & \text { Gravity Drain Line } \\ \text { HELIUM } & \text { Helium leak test } \\ \text { HLLCP } & \text { High Liquid Level Conductivity Probe } \\ \text { HPFP } & \text { High Point Flush Pit } \\ \text { I } & \text { Interior } \\ \text { IAL } & \text { Intra-Area Line } \\ \text { ITPFC } & \text { In-Tank-Precipitation Filter Cell } \\ \text { JB } & \text { Junction Box } \\ \text { LDB } & \text { Leak Detection Box } \\ \text { LPPP } & \text { Low Point Pump Pit } \\ \text { LPS } & \text { Leak Probe Sleeve } \\ \text { MLDB } & \text { Modified Leak Detection Box } \\ \text { OD } & \text { Outside Diameter } \\ \text { PHOTO } & \text { Photographs by Non-Remote Technique } \\ \text { PP } & \text { Pump Pit } \\ \text { psig } & \text { pounds per square inch gauge } \\ \text { PSP } & \text { Periscopic Photography } \\ \text { PT } & \text { Pump Tank } \\ \text { RCP } & \text { Reinforced Concrete Pipe } \\ \text { SRS } & \text { Savannah River Site } \\ \text { SSD } & \text { Storm Sewer Drain } \\ \text { SSMH } & \text { Storm Sewer Manhole } \\ \text { STE } & \text { Shift Technical Engineer } \\ \text { SWS } & \text { Storm Water Sewer } \\ \text { UT } & \text { Ultrasonic Test } \\ \text { VB } & \text { Valve Box } \\ \text { VP } & \text { Video Photograph } \\ \text { WAP } & \text { Wide-Angle Photography } \\ \text { WLE } & \text { Waste Line Encasement } \\ \text { WME } & \text { Waste Management Engineering } \\ \text { WSRC } & \text { Westinghouse Savannah River Company } \\ \text { WT } & \text { Waste Transfer Line } \\ & \end{array}$


This page intentionally left blank. 
WSRC-TR-2000-00067

Annual Waste Tank

Inspection Program - 1999

Introduction

\section{Introduction}

Aqueous radioactive wastes from Savannah River Site (SRS) separations processes are contained in large underground carbon steel tanks. Inspections made during 1999 to evaluate these vessels and auxiliary appurtenances along with evaluations based on data accrued by inspections performed since the tanks were constructed are the subject of this report. 
This page intentionally left blank. 
WSRC-TR-2000-00067

Annual Waste Tank

Inspection Program - 1999

\section{Summary}

The 1999 inspection program revealed that the structural integrity and waste confinement capability of the Savannah River Site waste tanks remained unchanged from 1998.

A total of 3979 photographs were made, 616 visual and video inspections were performed, and 12 helium leak tests were conducted. 
This page intentionally left blank. 


\section{Inspection Program}

\section{Background}

Alkaline aqueous radioactive wastes produced at the Savannah River Site are received and managed in large underground tanks. The waste came primarily from nuclear fuel reprocessing operations in the separations areas ( $\mathrm{F}$ and $\mathrm{H}$ ) and contains most of the radioactive fission products from SRS operations. The waste stored in the tanks is present in three phases: sludge, supernate, and salt formed by supernate evaporation and cooling. The supernate and salt phases consist primarily of $\mathrm{NaNO}_{3}$ and $\mathrm{NaNO}_{2}$. The fission product content is 1 to 20 curies per gallon for the supernate and 1 to 5 curies per gallon for the salt. The sludge consists primarily of $\mathrm{MnO}_{2}$ and $\mathrm{Fe}(\mathrm{OH})_{2}$ with a fission product content up to 950 curies per gallon.

Waste tank leak detection capabilities are essential to meet the primary objective of the SRS radioactive waste management program: to manage the waste in such a manner as to minimize the radiation exposure and associated risk to man and his environment over the lifetime of the radionuclides.

The detection of leaked waste is based on two principles: disappearance of material from its proper location and appearance of material in an improper location. At SRS, primary reliance is on the latter because the quantity of the waste detectable in an improper location is much less than that detectable by inventory change in a large tank. Capacity of SRS tanks is 0.75 to 1.3 million gallons. Although rigorous tank inventory surveillance is practiced, primary leak detection methods rely on automatic surveillance of those areas into which the leaked waste is most likely to migrate.

The annulus of each double-wall tank is equipped with at least two single-point conductivity probes for leak detection. These probes are located at the bottom of the annulus and on opposite sides of the tank. The single-wall tanks are built on slabs with a network of leak collection channels that drain to a common sump. Continuous sump level monitoring and frequent sump liquid sampling provide the leak detection. Besides the automatic surveillance, routine direct visual surveys are made in the annular spaces, and nonroutine direct visual surveys are made in primary tanks through opened access risers and/or inspection ports in the roof.
In 1961-62, following leakage of waste into the annuli of Tanks 9,10,14, and 16, the first remote imaging inspections were made of some tanks using a periscope. Random inspections continued through 1970. A program was initiated in November 1971 to periodically inspect all waste tanks, using remote visual imagery techniques to monitor for corrosion and other degradation, waste leakage, anomalies of any type, and to investigate process or equipment concerns.

Steel thickness measurements have been made periodically of waste tanks using ultrasonic techniques to monitor for general corrosion. An analog-type instrument was used in 1967 and 1969 to measure the thickness of the primary wall of selected double-wall tanks. In 1972, a more precise instrument was put in service. About 24,000 measurements made over a period of 14 years (1972 through 1985) indicated that no thinning of SRS tanks had occurred. The only tank at SRS that has experienced detectable corrosion is Tank 23, a tank with a unique service history. The upper wall interior surfaces show general corrosion with mild pitting. The pitting is broad but shallow. This tank was used to receive contaminated water from 244-H, the Receiving Basin for Off-Site Fuels, and 245-H, the Resin Regeneration Facility. Steel thickness measurements were resumed in 1994 using an updated ultrasonic testing (UT) system.

Inspections are complicated by factors such as radiation and radioactive contamination, remote operation as far as 40 feet below grade, and insertion of equipment through small (generally 5 to 8 -inchdiameter) access openings. Inspection techniques to circumvent these difficulties have been developed; they yield quality visual images and thickness measurements. The techniques include photographic systems, closed circuit television systems, and ultrasonic systems to measure steel thicknesses.

Waste tank inspection has been important in leak detection. The leaksites in nine of eleven cracked tanks have been identified by direct visual inspection or by one of the remote inspection techniques. Since the inspection program was initiated in 1971, six tanks were found to have leaksites that were not recognized before the program was implemented. In 
the double-wall tanks, annulus conductivity probes were not activated by these leaks because of the small amount of leakage. The leaked waste evaporated to dryness, sealing the cracks before any leaked waste reached a leak detection probe. However, remote inspections detected the dry deposits of leaked waste in the annuli of these tanks.

The waste tank in-service inspection program is an ongoing program. This report gives results of the 1999 inspections and summarizes significant findings of previous in-service inspections for each waste tank.

\section{Tank Description}

SRS has subsurface storage tanks of four different designs. All of the tanks are constructed of carbon steel and reinforced concrete. They, serve as containment vessels for storage and processing of radioactive wastes. Appendix A lists tank location, design type, project number, and construction period. A brief description of the different tank designs is given in the following paragraphs.

\section{Type I Tanks}

The 12 original storage tanks constructed between 1951 and 1953 are designated Type I tanks. Tanks 1 through 8 are in F Area and Tanks 9 through 12 are in $\mathrm{H}$ Area. Each primary tank has a capacity of
750,000 gallons, is 75 feet in diameter and $241 / 2$ feet high. Figure 1 shows the essential features of Type I tanks, including the primary tank, the secondary pan, and the concrete support structure.

The primary container is a closed cylindrical tank with flat top and bottom constructed from 1/2-inchthick steel plates. The top and bottom are joined to the cylindrical sidewall by curved knuckle plates. The primary tank is set within a circular pan of $1 / 2$ inch-thick steel plates. The annulus pan is 5 feet deep and 5 feet larger in diameter than the primary tank, thus forming an annular space $21 / 2$ feet wide. The tank and pan are set on a 30-inch-thick base slab and are enclosed by a cylindrical 22-inch-thick reinforced concrete wall and a flat concrete roof, also 22 inches thick. There are twelve 2-foot-diameter concrete columns within the primary tank to support the roof. Each column has a flared capital and is encased in 1/2-inch-thick steel plate.

A 9-foot layer of earth was placed over the tanks for radiation shielding. Cooling for each type I tank is provided by 36 parallel (water pipe) cooling coils.

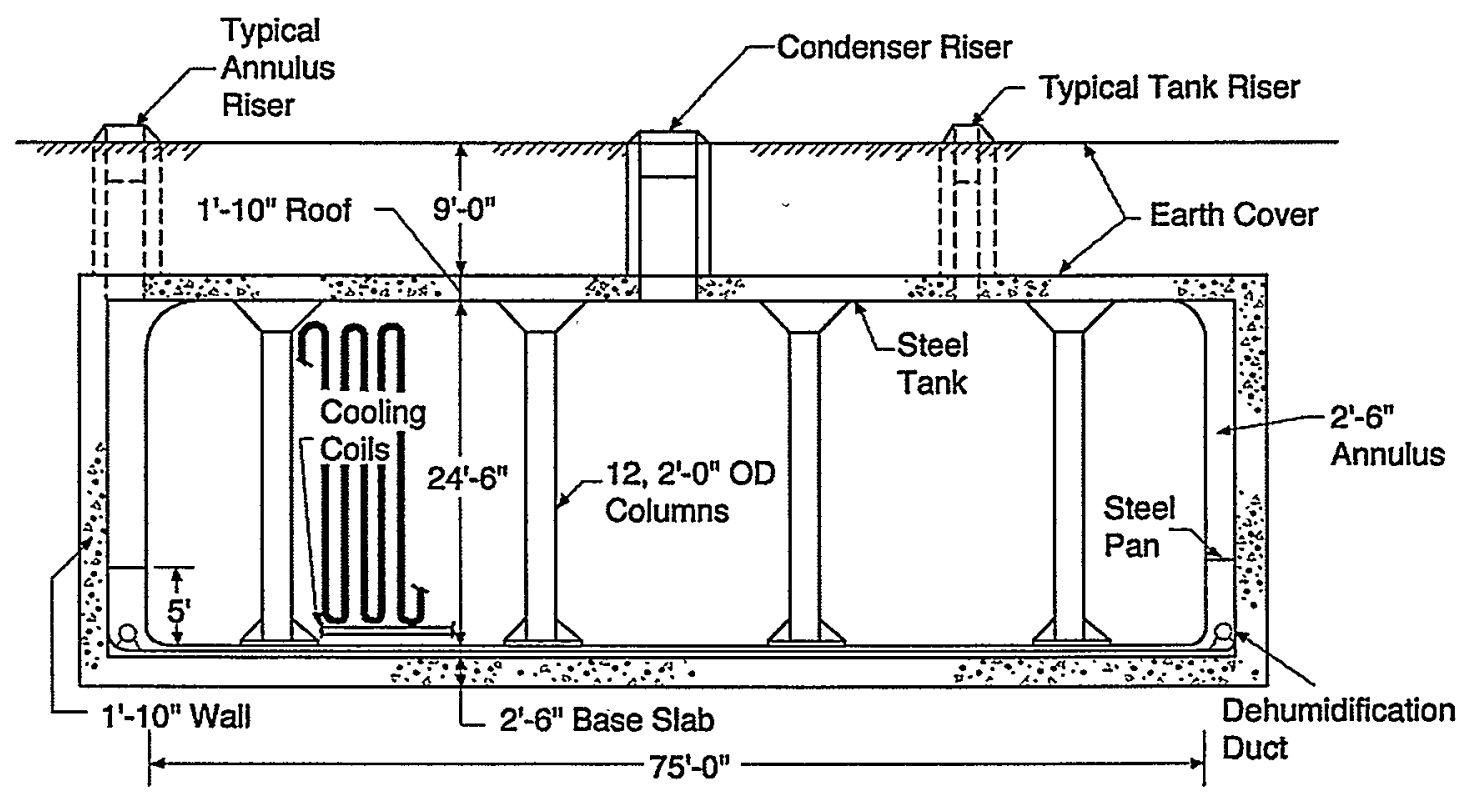

Figure 1. Cooled Waste Storage Tank, Type I (Original 750,000 Gallons). 
A dehumidification duct in the annulus of each tank is routed from the tank top to the bottom of the annulus, where it encircles the tank. The duct has distribution outlets and its cross-sectional area decreases as the distance from the air supply increases. Access to the tank interior is provided at eight locations, and to the annular space at four locations, through riser pipes. Each of the 12 riser pipes is capped at the top with a concrete plug. Each plug is provided with two 5-inch-diameter ports equipped with removable plugs. Some of these ports provide access for inspections.

All welds in the pan and primary tank were radiographically inspected, defects were corrected, and the welds were rechecked radiographically. The welds in the flat bottoms of both the pan and the tank were vacuum-tested for leaks. Additionally, both vessels were hydrostatically tested. The water was maintained at full height in the tank for 24 hours before inspection for leaks was made. Cooling water piping was hydrostatically tested at 300 psig and then leak-tested with 100 psig air pressure in the piping.

\section{Type II Tanks}

Tanks 13 through 16, constructed in $\mathrm{H}$ Area in 1955 and 1956, are designated Type II tanks. Figure 2 is a cross section of this type. Each primary tank has a capacity of $1,030,000$ gallons and is 85 feet in diameter and 27 feet high.

The primary container for Type II tanks consists of two concentric steel cylinders assembled with a flat bottom and a flat top into a form somewhat like a doughnut. The top and bottom are joined to the outer cylinder by rings of curved knuckle plates. The inner cylinder is flared at the top to accommodate the roof support column. This cylinder is joined to the flat steel top with a continuous butt weld and to a base fastened to the bottom with a continuous T-weld. Steel thicknesses are:

$$
\text { Plate }
$$
Thickness, inch

$\begin{array}{ll}\text { Top and bottom } & 1 / 2 \\ \text { Upper knuckle } & 9 / 16 \\ \text { Wall } & 5 / 8 \\ \text { Lower knuckle } & 7 / 8\end{array}$

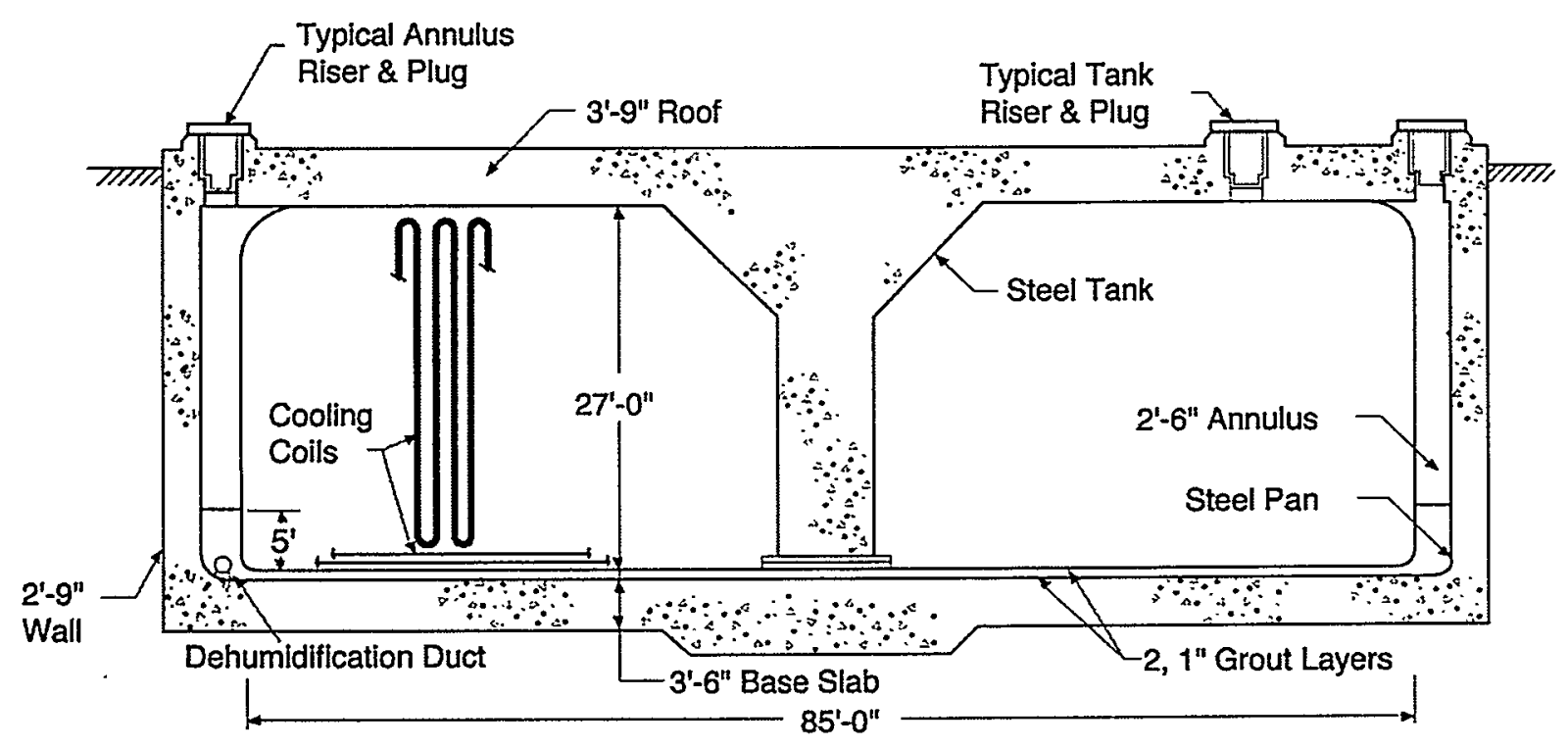

Figure 2. Cooled Waste Storage Tank, Type II (Original 1,030,000 Gallons). 
The primary tank is set on a 1-inch sand bed within a circular pan of 1/2-inch thick steel plate, 5 feet deep and 5 feet larger in diameter than the primary tank, thus forming an annular space $21 / 2$ feet wide. The tank and pan assembly is surrounded by a cylindrical reinforced concrete enclosure with a 33-inch-thick wall and a flat concrete roof that is 45 inches thick. The tank and pan assembly and the surrounding wall are set on a foundation slab that is 42 inches thick. The roof is supported by both the wall and a central concrete column that fits within the inner cylinder of the vessel. The 45 -inch-thick concrete roof provides radiation shielding; therefore, no earth overburden is required. Cooling for each Type II tank is provided by 44 parallel (water pipe) cooling coils. Access to the tank interior is provided at eight locations, and to the annular space at four locations, through riser pipes. Each of the 12 riser pipes is capped at the top with a concrete plug. Each plug is provided with two 5-inch-diameter ports equipped with removable plugs. The ports provide access for inspection. In addition to the four annulus risers, other access openings (10 to 14 additional openings per tank) have been drilled into the annulus of each of these tanks to permit inspection of seventy-three to ninety-six percent of the exterior walls of the primary vessels.

A dehumidification duct in the annulus of each tank is routed from the tank top to the bottom of the annulus, where it encircles the tank. The duct has distribution outlets and its cross-sectional area decreases as the distance from the air supply increases.

All welds in the primary tanks were radiographically inspected, defects were corrected, and the welds were rechecked radiographically. However, the annulus pans were not inspected radiographically. The welds in the flat bottoms of these pans and the primary tanks were vacuum-tested for leaks, and the primary and secondary vessels were hydrostatically tested. Cooling water piping was hydrostatically tested at $300 \mathrm{psig}$ and then leak-tested, with $100 \mathrm{psig}$ air pressure in the piping.

\section{Type IV Tanks}

Tanks 17 through 24 are single-wall-uncooled tanks. These tanks were designed for storage of waste that does not require auxiliary cooling. Tanks 17 through 20 were constructed in F Area in 1958 and Tanks 21 through 24 were constructed in $\mathrm{H}$ Area between 1959 and 1961. Each tank has a capacity of 1,300,000 gallons and is 85 feet in diameter and 34 feet high (Figure 3).

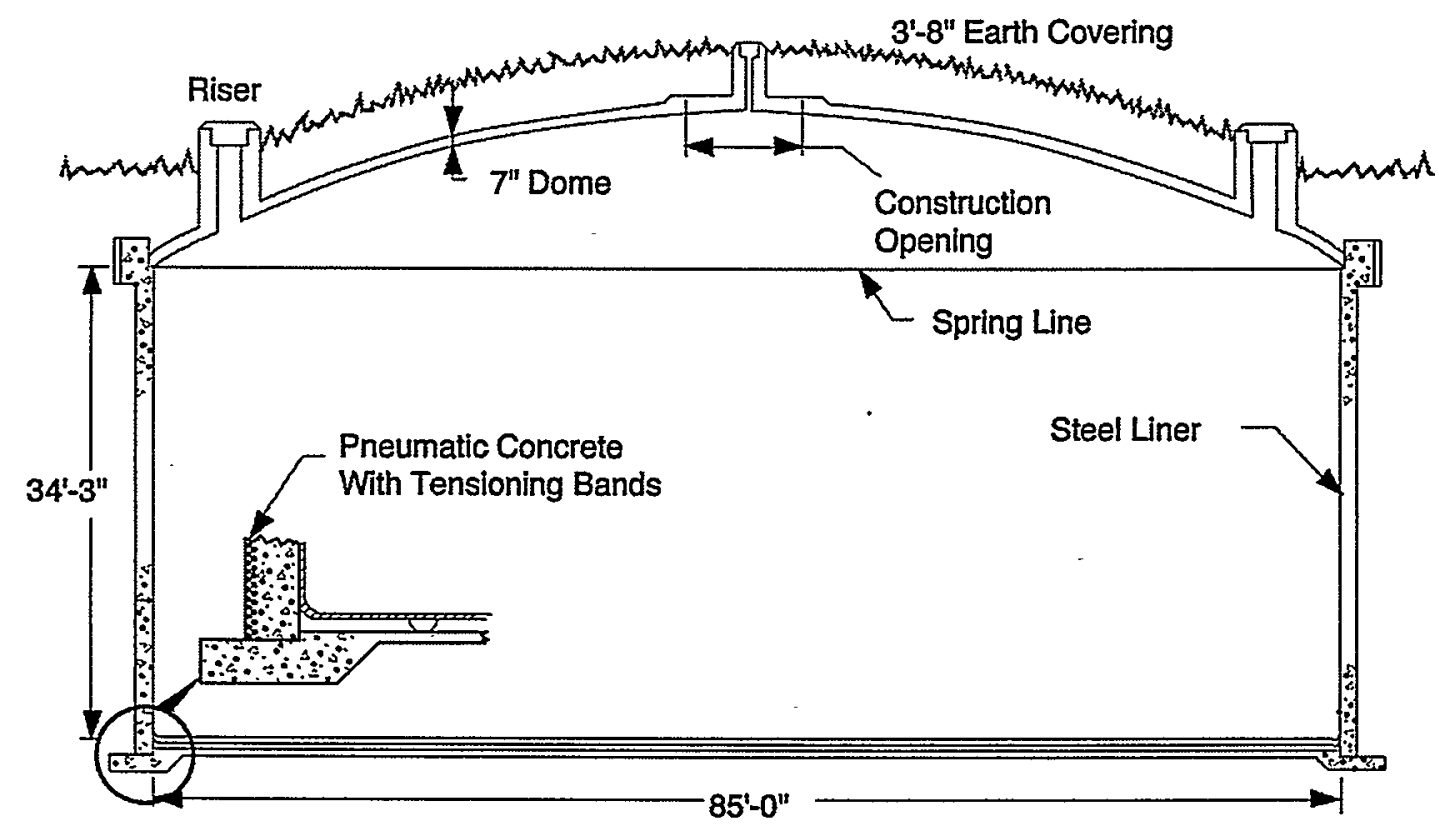

Figure 3. Uncooled Waste Storage Tank, Type IV (Prestressed Concrete Walls, 1,300,000 Gallons). 
Each Type IV tank is basically a steel-lined, prestressed-concrete tank in the form of a vertical cylinder with a domed roof. Carbon steel plates, 3/8 inch thick, were used to form the cylindrical sides and flat bottom portion of the steel liners. The knuckle plates at the junction of the bottom and the sidewall are 7/16 inch thick. Concrete was built up around the steel vessel by the "shotcrete" technique.

Radiation shielding of the Type IV tanks in F Area was accomplished by applying at least 32 inches of earth over each of the 7-inch-thick concrete domes. H-Area tanks were shielded similarly, except that the earth cover was at least 44 inches thick to accommodate a somewhat higher radiation level from the waste.

Access to the interior of the tank is provided at six locations through riser pipes. Each riser pipe is capped at the top with a concrete plug. Some of these risers provide access for inspection.
All welds in the steel liners were radiographically inspected. All of the welded tank-bottom seams and the upper seams of the knuckle rings were vacuum leak-tested. Prior to the back-filling operation, each tank was hydrostatically tested by filling with water to the normal fill line. The tank was allowed to remain filled until it was to be placed in use for waste storage.

\section{Type III Tanks}

The most recently constructed tanks are designated as Type III tanks (Figure 4). Twenty-seven tanks were built between 1967 and 1981. Tanks 25 through 28, 33 and 34 , and 44 through 47 are located in F Area. Tanks 29 through 32, 35 through 43, and 48 through 51 are located in H Area.

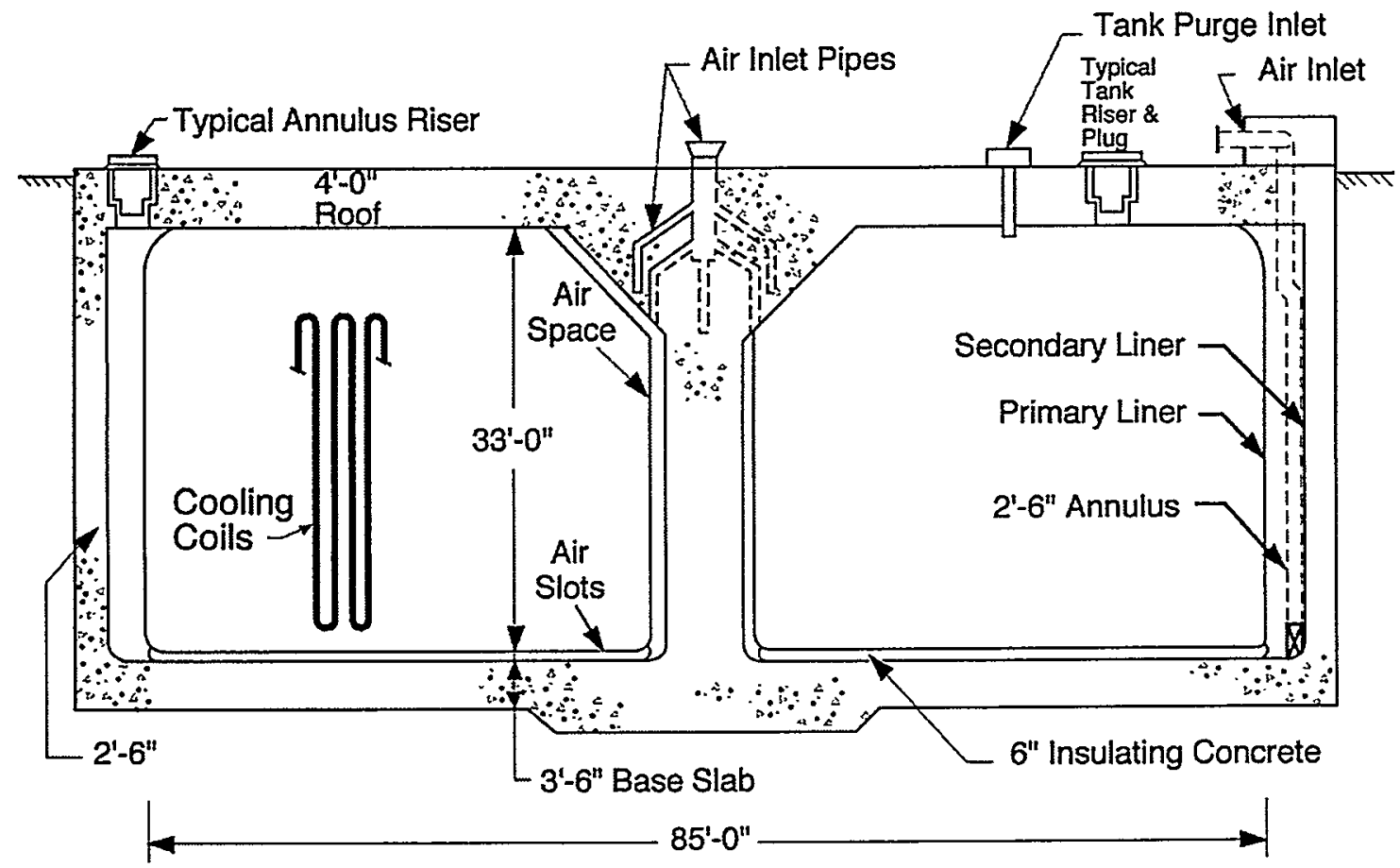

Figure 4. Cooled Waste Storage Tank, Type III (Stress Relieved Primary Liner, 1,300,000 Gallons). 
The Type III tank design was developed after an investigation into the causes of the leaks from the primary vessel of the Type I and Type II tanks. The study concluded that the leak-producing mechanism was nitrate-induced, stress-corrosion cracking at sites in or near the weld seams, and that stress relieving after fabrication should eliminate the cracking. For the type III tanks, means were provided for heating each finished tank to relieve the stresses generated during fabrication. In addition, some stress patterns were avoided, or minimized, by mounting the roof supporting column on the foundation pad rather than on the bottom of the primary tank (as in Types I and II), and by providing an annular clearance around the roof supporting column. Each primary tank holds $1,300,000$ gallons and is 85 feet in diameter and 33 feet high.

Type III tanks are similar to the doughnut-like design of Type II tanks. Each primary vessel is made of two concentric cylinders joined to washer-shaped top and bottom plates by curved knuckle plates. Steel thicknesses are:

\begin{tabular}{lc} 
Plate & Thickness, inch \\
\hline Top and bottom & $1 / 2$ \\
Upper knuckle & $1 / 2$ \\
Outer wall & \\
Upper band & $1 / 2$ \\
Middle band & $5 / 8$ \\
Lower band & $3 / 4$ \\
Inner wall \\
Upper band \\
Lower band \\
Lower knuckle \\
Outer (tanks 25-28 and \\
$\quad$ 33-51) \\
$\quad$ (tanks 29 through \\
32) \\
Inner \\
\end{tabular}

The primary tank is set on a 6-inch bed of insulating concrete within the secondary containment vessel. The concrete bed is grooved radially so that ventilating air can flow from the inner to the outer annulus. If any waste were to leak from the tank bottom or center annulus wall, liquid would move through the grooves, facilitating detection in the outer annulus.

The secondary vessel is 5 feet larger in diameter than the tank, thus providing an outer annulus $21 / 2$ feet wide. The secondary vessel is made of $3 / 8$-inch-thick steel throughout. Its sidewalls rise to the full height of the primary tank. The nested two-vessel assembly is surrounded by a cylindrical reinforced concrete enclosure with a 30-inch-thick wall. The enclosure has a 48-inch-thick flat reinforced concrete roof that is supported by the concrete wall and a central column that fits within the inner cylinder of the vessel. The 48 -inch-thick concrete provides radiation shielding; hence, no earth overburden is required.

Cooling for the Type III tanks is provided by either deployable (water pipe) cooling coil bundles installed through risers in the tank top, or 23 parallel (water pipe) cooling coils distributed throughout the tank.

A dehumidification duct in the annulus of each tank is routed from the tank top to the bottom of the annulus where it encircles the tank. The duct has distribution outlets and its cross-sectional area decreases as distance from the air supply increases. In these tanks, additional airflow is directed through the inner annulus, passing beneath the primary tank through radial grooves in the concrete base slab, and is exhausted into the outer annulus.

Tanks 29 through 34 were placed in service prior to 1976. These tanks were constructed with annulus riser pipes at four locations, providing inspection access through 5-inch-diameter ports. All other Type III tanks were placed in service after 1976 and have annulus riser pipes at 18 locations, that are 8-inches in diameter. These ports are equidistant around the tank and provide for inspection of all of the exterior wall of the primary vessel. In 1982, fourteen to sixteen additional 8-inch diameter ports per tank were drilled in the tops of Tanks 29 through 34 to provide adequate access ports for inspection of all of the exterior wall of their primary vessels. All Type III tanks have interior riser pipes at various locations that provide inspection access through ports with diameters ranging from 5 to 8 inches. All inspection access ports are equipped with removable plugs.

All butt welds on the primary tanks were radiographically inspected, except welds on the horizontal roof surface. On the secondary vessels of Tanks 29 through 34, all butt welds joining bottom plates, knuckle plates, and the lowest courses of center-column and outer-wall plates, were radiographically inspected. On all other Type III tanks, all plate welds in the secondary tanks were radiographically inspected. All defects were corrected and the welds were rechecked radiographically.

The Quality Assurance Program included inspection of all radiographs by two independent groups of certified weld inspectors, and all radiographs were permanently stored for future reference. All spots on the inside or outside of the primary tanks and the 
inside of the secondary tanks, where clips or lugs were removed and where other excisions were made, were examined by magnetic particle or liquid penetrant techniques, and any defects were repaired.

All butt welds on the secondary tanks were vacuum leak-tested. All welds in the bottom assemblies of the primary tanks, including knuckle rings and lowest course welds, were vacuum leak-tested before each bottom assembly was lowered into final position, and then tested a second time after the stress-relieving operation. A full hydrostatic test, the filling of each primary tank to a depth of 32 feet and allowing it to stand 48 hours, was conducted after stress relieving. No leaks were found by the hydrostatic tests. All circumferential welds in the pipe loops of the deployable cooling coil bundles below the 1/2-inchthick plate at the base of the riser plug were radiographed. The assembled cooler piping was tested hydrostatically to 500 psig and halide leaktested at $300 \mathrm{psig}$. Welds in the distributed cooling coils were radiographed and similarly leak-tested.

The primary tank was stress-relieved in place after all high temperature work (other than roof attachments) had been completed. Full stress relief, at $1100^{\circ} \mathrm{F}$, was accomplished in accordance with the general requirements of the ASME Boiler and Pressure Vessel code.

\section{Inspection Methods}

Techniques have been developed for remote examination and evaluation of the waste tanks and waste tank ancillaries. For visual imaging, direct photography systems developed at SRS were the primary method used. Closed circuit television systems were also used where direct photography was not possible or where these systems provided a more comprehensive examination. Only the direct photography systems will be described since the video systems are similar to systems used widely in industry.

Wide-angle direct photography was used for general inspections of double-wall tank annuli and the primary vessels of both double-wall tanks and singlewall tanks. This technique used a camera that surveys a large area in a single photograph. The camera used for wide-angle photography was a Contax G1 camera body, with a Zeiss Hologon $16 \mathrm{~mm} \mathrm{f} / 8$ fixed aperture lens. This lens is distortion free with a field of view of approximately 100 degrees. A bank of four electronic flash units was synchronized with these cameras to provide illumination. This camera is not shielded since residence time in a tank is minimal.
Another direct photography technique was used for detailed inspections. The camera is shielded to reduce the degrading effect of ionizing radiation on the photographic film. The camera's residence time in a waste tank for this technique is longer than the wideangle direct photographic technique (i.e., a few minutes versus a few seconds); hence, shielding is required. The camera used was the Contax G1 camera with a Zeiss Hologon $16 \mathrm{~mm} \mathrm{f} / 8$ lens, the same as used for the wide-angle direct photography. Illumination is provided by a single electronic flash unit. 
WSRC-TR-2000-00067

Annual Waste Tank

This page intentionally left blank. 


\section{Program Implementation}

\section{Visual Imagery}

The 1999 inspection program used two visual imagery techniques: photography and closed circuit television. The primary inspection methods were direct photography techniques; e.g., making a series of photographs providing detailed views of the tank and wide-angle photography for obtaining overviews of large areas. Closed circuit television systems were generally used to further investigate conditions found during scheduled inspections and to troubleshoot process problems in tanks and ancillaries.

The inspection program objective to continuously evaluate the waste tanks was satisfied in 1999 by photographic and videotape documentation. Inspections were made through all accessible annulus risers of the double-wall tanks, and at least one inspection was made in the interior of each singlewall tank.

For Tanks 1 through 12, inspections are limited to no more than $25 \%$ of the exterior of the primary vessel wall and the annular space due to limited annulus access. This is considered adequate since the tanks are inactive; i.e., waste is not routinely transferred to or from them. These tanks are continuously monitored for leakage by instrumentation installed in their annuli. Additionally, for those tanks that have known leaksites in the primary vessel, the supernate phase has been removed, minimized, or the level lowered below the level of known leaksites.

\section{Inspection Results}

The 1999 inspection program was successfully completed. The annuli of all double-wall tanks were inspected via all accessible risers, and the interiors of single-wall tanks remaining in service were inspected. Other inspections of waste tanks and ancillaries were performed as required by operating conditions and equipment performance.

Inspection in the annulus of Tank 11 revealed nodules on the steel pan, the secondary containment vessel, which was potentially an indication of through-wall penetrations. The nodules appeared to contain corrosion products and a white colored substance possibly associated with concrete from the outside of the pan. This raised concerns for throughwall penetration. A pressure wash was used to remove the nodules beneath the south riser. Subsequent inspection revealed the pan to be in good condition. No significant pitting was observed. The area beneath the nodules had experienced mild surface corrosion.

Tank 14 inspection revealed that nodules formed of dry leaked waste had fallen away from three leaksites in the tank wall. These leaksites are located beneath risers 13,151, and 259. At two other leaksites beneath riser 259 , the volume of dry leaked waste had increased slightly, indicating that additional waste had seeped from the tank.

Tank 15 inspection revealed a thin trace of waste highlighting the crack beneath riser 55 . This waste was not present when inspected in March 1998. Evidently the waste leached from the crack when ambient air humidity was high.

A degraded concrete condition was observed in Tank 23. The inspection showed that the base of the concrete dome was cracked or crushed for about fifteen feet immediately above the interface with the tank wall. Structural analysis concluded that the acceptance criteria are still met, and the tank remains in normal service.

Rainwater continued to leak into the annulus of most tanks. Inleakage was evidenced primarily by surface stains, occasionally by calciferous deposits, changed configuration in leaked waste in the annulus, and by mild surface corrosion where annulus ventilation was inadequate to maintain the annulus dry.

Except as noted above, the conditions of the tanks remained essentially unchanged from the conditions reported in 1998. Details and results of inspections of the tanks and ancillaries performed in 1999 are listed in Appendix B. 


\section{Summary of Inspection Results}

The following is a brief description of tank conditions as revealed by inspections and examinations made through 1999.

\section{Tank 1}

Tank 1 was placed in.service in 1954. A small amount of dry waste was observed on the annulus floor in 1969. Subsequent inspections have revealed no additional leakage. Inspection of the exterior wall of the primary vessel is limited to $25 \%$ using existing inspection techniques through the four risers that provide access to the annulus. Examination of the observable portion of the tank wall has not revealed the location of the leak(s). Inspection photographs of the steel surface of the tank and the annulus have shown no significant surface corrosion or other anomalies. Ultrasonic measurements made in 1978, 1979, 1981, 1983, and 1985 showed that no detectable thinning of the tank wall had occurred.

\section{Tank 2}

Tank 2 was placed in service in 1955. Examinations of the observable portion (25\%) of the exterior of the primary vessel wall and the annulus have shown no leakage, significant surface corrosion, or other anomalies. Ultrasonic measurements made in 1967, $1972,1973,1977,1981$, and 1985 showed no detectable thinning of the tank wall.

\section{Tank 3}

Tank 3 was placed in service in 1956. Examinations of the observable portion (25\%) of the exterior of the primary vessel wall and the annulus have shown no leakage, significant surface corrosion, or other anomalies. Ultrasonic measurements made in 1973, 1977,1981 , and 1985 showed no detectable thinning of the tank wall.

\section{Tank 4}

Tank 4 was placed in service in 1961. Examinations of the observable portion (25\%) of the exterior of the primary vessel wall and the annulus have shown no leakage, significant surface corrosion, or other anomalies. Ultrasonic measurements made in 1973, 1977,1981 , and 1985 showed no detectable thinning of the tank wall.

\section{Tank 5}

Tank 5 was placed in service in 1959. Examinations of the observable portion (25\%) of the exterior of the primary vessel wall and the annulus have shown no leakage, significant surface corrosion, or other anomalies. Ultrasonic measurements made in 1973, 1977,1981 , and 1985 showed no detectable thinning of the tank wall.

\section{Tank 6}

Tank 6 was placed in service in 1964. Examinations of the observable portion (25\%) of the exterior of the primary vessel wall and the annulus have shown no leakage, significant surface corrosion, or other anomalies. Ultrasonic measurements made in 1974, $1977,1978,1979,1981$, and 1985 showed no detectable thinning of the tank wall.

\section{Tank 7}

Tank 7 was placed in service in 1954. Examinations of the observable portion (25\%) of the exterior of the primary vessel wall and the annulus have shown no leakage, significant surface corrosion, or other anomalies. Ultrasonic measurements made in 1974, $1979,1981,1983$, and 1985 showed no detectable thinning of the tank wall.

\section{Tank 8}

Tank 8 was placed in service in 1956. Examinations of the observable portion (25\%) of the exterior of the primary vessel wall and the annulus have shown no leakage, significant surface corrosion, or other anomalies. Ultrasonic measurements made in 1973, 1977,1981 , and 1985 showed no detectable thinning of the tank wall.

\section{Tank 9}

Tank 9 was placed in service in 1955. Leakage from the tank primary vessel into the annulus pan may have occurred as early as 1955 when the "necklace" alarm, a conductivity leak detection device, shorted out permanently. Leakage was not certain until liquid waste was observed in the annulus pan in 1957. Currently, the annulus pan contains 8 to 10 inches of dry leaked waste. Examinations of the observable portion. (25\%) of the exterior of the primary vessel wall have shown three leaksites high on the tank wall; 269,271 , and 276 inches above the tank bottom. None of these leaksites is the source of the leaked waste in the annulus pan. The waste leaked at these sites was only enough to form localized small nodules. The leak(s) that are the source of the waste in the annulus pan have not been observed. Inspections have shown no significant surface corrosion, and the ultrasonic measurements made in 1979 and 1983 showed no detectable thinning of the tank wall. 


\section{Tank 10}

Tank 10 was placed in service in 1955 . The first indication that Tank 10 had leaked was in 1959 when dry waste was discovered in the annulus pan during a visual inspection. Currently, the annulus pan contains about 2 inches of dry leaked waste. Examinations of the observable portion $(25 \%)$ of the exterior of the primary vessel wall have not shown the source of the leaked waste or any other leaksite(s). Inspections have shown no significant surface corrosion, and the ultrasonic measurements made in 1979 and 1983 showed no detectable thinning of the tank wall.

\section{Tank 11}

Tank 11 was placed in service in 1955 . Twenty-five percent of the exterior of the primary vessel wall is observable via the four risers that provide access to the annulus. Inspections performed in 1974 revealed two leaksites. The leaksites are 189 and 235 inches above the tank bottom. Inspections have shown no significant surface corrosion, and ultrasonic measurements made in 1973, 1977, 1981, and 1985 showed no detectable thinning of the tank wall.

\section{Tank 12}

Tank 12 was placed in service in 1956. Twenty-five percent of the exterior of the primary vessel wall is observable via the four risers that provide access to the annulus. Inspections in 1974 revealed two leaksites. The leaksites are 93 and 105 inches above the tank bottom. Inspections have shown no significant surface corrosion, and ultrasonic measurements made in 1972, 1973, 1977, 1981, 1983 , and 1985 showed no detectable thinning of the tank wall.

\section{Tank 13}

Tank 13 was placed in service in 1956. Ninety percent of the exterior of the primary vessel wall is observable via the 13 risers that provide access to the annulus. Inspections in 1977 revealed a leaksite 279 inches above the tank bottom. In 1980, another leaksite was discovered 269 inches above the tank bottom. Inspections have shown no significant surface corrosion, and ultrasonic measurements made in 1974,1979 , and 1985 showed no detectable thinning of the tank wall.

\section{Tank 14}

Tank 14 was placed in service in 1957. The first indication that tank 14 had leaked was in 1959 when dry leaked waste was observed in the annulus pan. Currently, the annulus pan contains 12 to 13 inches of dry leaked waste. Eighty-nine percent of the exterior of the primary vessel wall is observable via the 18 risers that provide access to the annulus. Inspections have located 33 leaksites and it is estimated that there are about 50 leaksites in this tank. All of the observed leaksites are near the bottom circumferential weld that is 2.5 feet above the tank bottom, except for one leaksite that was observed approximately 24 feet above the tank bottom. Inspections have shown no significant surface corrosion, and ultrasonic measurements made in 1979 and 1983 showed no detectable thinning of the tank wall.

\section{Tank 15}

Tank 15 was placed in service in 1960 . Inspections in 1972 below one of the four risers providing access to the annulus revealed two leaksites near the bottom circumferential weld about 2.5 feet above the tank bottom. Twelve additional risers were installed, increasing the observable portion of the primary vessel wall from $25 \%$ to $96 \%$. Inspections in 1973 , via the additional risers, revealed eleven other leaksites. Later, inspections revealed three other sites where cracks penetrated the steel wall, one was observed in 1994 and two were observed in 1997.

Inspections have shown mild corrosion of the steel surfaces in the tank annulus. Ultrasonic measurements made in 1972,1977, 1980, and 1984 showed no detectable thinning of the tank wall.

\section{Tank 16}

Tank 16 was placed in service in 1959. Liquid waste was detected in the annulus pan in 1959. Seventythree percent of the exterior wall of the primary vessel is observable via the sixteen risers that provide access to the annulus. Inspections in 1961 and 1962, through 13 risers, revealed about 175 leaksites in the tank wall. In October 1961 and March 1962, two 5 3/4-inch-diameter samples were cut from the top horizontal circumferential weld of the tank wall about 40 feet apart. Metallurgical examination indicated the cause of the cracks was nitrate-induced stress corrosion. Extensive inspection performed since 1972 indicated that the primary vessel wall has 300 to 350 leaksites. In $1978,70 \%$ of the leaked waste in the annulus pan was removed, leaving an insoluble heel containing approximately 30,000 curies $137 \mathrm{Cs}$. Waste removal from the interior of the primary vessel was completed in 1980 . Inspections have shown no significant surface corrosion. No ultrasonic steel thickness measurements of the tank were made because of the number of leaksites and the presence of leaked waste deposits on the primary vessel exterior. This tank is presently "out of service". 


\section{Tank 17}

Tank 17 was placed in service in 1961. Examinations of the steel liner have shown no evidence of failure, significant surface corrosion, or other anomalies. Tank 17 was removed from service and closed on or about December 15, 1997.

\section{Tank 18}

Tank 18 was placed in service in 1959. Examinations of the steel liner have shown no evidence of failure, significant surface corrosion, or other anomalies. Ultrasonic measurements made in 1977,1980 , and 1983 showed no detectable thinning of the liner bottom.

\section{Tank 19}

Tank 19 was placed in service in 1961 and emptied in 1981. The tank has remained empty except for ballast water. Examinations of the steel liner have revealed two failures; i.e. sites where inleakage had occurred. The failures are in the wall of the steel liner at heights of 317 inches and 330 inches. Inspection records photographically document that these leaksites existed before 1994. However, inspections made from the interior of this single-wall (visual inspection of the exterior is not possible) had to track changes in artifacts at the sites by periodic observation to judge that inleakage had occurred. Ultrasonic measurements made in 1982 and 1985 showed no-detectable-thinning-of-the-liner-bottom.

\section{Tank 20}

Tank 20 was placed in service in 1960 . Examinations of the steel liner have revealed four failure sites. In 1983 , leaksites were observed in the wall of the steel liner at heights of 22, 24.5, and 26.5 feet. In 1990, a leaksite was confirmed in the liner wall at a height of 26.25 feet. This site had been suspect since 1984 . This is a single-wall tank with no annulus. The leaksites in the steel liner were detected by inspections made from the tank interior, since inspection of the exterior was not possible. Artifacts observed on the interior wall indicated water had leaked through the steel liner into the tank. It is possible that a small quantity of waste may have leaked from the steel liner. However, groundwater monitoring has given no indication that waste escaped the encasement. Tank 20 was removed from service and closed on or about July 30, 1997.

\section{Tank 21}

Tank 21 was placed in service in 1961. Examinations of the steel liner have shown no evidence of failure, significant surface corrosion, or other anomalies. Ultrasonic measurements made in 1973, 1977, 1980, and 1983 showed no detectable thinning of the liner bottom.

\section{Tank 22}

Tank 22 was placed in service in 1965. Examinations of the steel liner have shown no evidence of failure, significant surface corrosion, or other anomalies. Water was discovered leaking through the concrete roof in 1994. Ultrasonic measurements made in 1974, 1977, 1980, and 1983 showed no detectable thinning of the liner bottom.

\section{Tank 23}

Tank 23 was placed in service in 1964. Examinations of the steel liner have revealed corrosion but no evidence of failure. Ultrasonic measurements made in 1973, 1977, 1980, and 1983 showed no detectable thinning of the liner bottom. Examinations of the steel liner have shown rust and tubercles on the surface of the upper portion. This tank served as a receiver tank for inhibited contaminated water from Buildings 244-H, the Receiving Basin for Off-Site Fuels, and $245-\mathrm{H}$, the Resin Regeneration Facility. The tank was filled to less than $50 \%$ capacity to maintain the remaining space for emergency use. This mode of operation exposed only the lower half of the tank to the inhibited contents and exposed the upper half of the tank to a warm humid atmosphere. -In-1984, rust-and-tubercles-were-cleaned-from-two small areas, exposing the steel surface. The cleaned liner surface was generally corroded with mild pitting. The pits were broad and shallow. In 1999, cracked or crushed concrete was noted in the tank dome, spanning about fifteen feet immediately above the tank wall.

\section{Tank 24}

Tank 24 was placed in service in 1963. Examinations of the steel liner have shown' no evidence of failure, significant surface corrosion, or other anomalies. Ultrasonic measurements made in 1984 showed no detectable thinning of the liner.

\section{Tank 25.}

Tank 25 was placed in service in 1980. Examinations of $100 \%$ of the exterior of the primary vessel wall and the annulus have shown no leakage, significant surface corrosion, or other anomalies. Ultrasonic thickness measurements made in 1979 and 1983 showed no detectable thinning of the tank wall. 


\section{Tank 26}

Tank 26 was placed in service in 1980. Examinations of $100 \%$ of the exterior of the primary vessel wall and the annulus have shown no leakage, significant surface corrosion, or other anomalies. Ultrasonic thickness measurements made in 1979 and 1983 showed no detectable thinning of the tank wall.

\section{Tank 27}

Tank 27 was placed in service in 1980. Examinations of $100 \%$ of the exterior of the primary vessel wall and the annulus have shown no leakage, significant surface corrosion, or other anomalies. Ultrasonic thickness measurements made in 1979 and 1983 showed no detectable thinning of the tank wall.

\section{Tank 28}

Tank 28 was placed in service in 1980. Examinations of $100 \%$ of the exterior of the primary vessel wall and the annulus have shown no leakage, significant surface corrosion, or other anomalies. Ultrasonic thickness measurements made in 1979 and 1983 showed no detectable thinning of the tank wall.

\section{Tank 29}

Tank 29 was placed in service in 1971. Examinations of $100 \%$ of the exterior of the primary vessel wall and the annulus have shown no leakage, significant surface corrosion, or other anomalies. Ultrasonic thickness measurements made in 1973 and 1974 showed no detectable thinning of the tank wall.

\section{Tank 30}

Tank 30 was placed in service in 1974. Examinations of $100 \%$ of the exterior of the primary vessel wall and the annulus have shown no leakage, significant surface corrosion, or other anomalies. Ultrasonic thickness measurements made in 1975 showed no detectable thinning of the tank wall.

\section{Tank 31}

Tank 31 was placed in service in 1972. Examinations of $100 \%$ of the exterior of the primary vessel wall and the annulus have shown no leakage, significant surface corrosion, or other anomalies.

\section{Tank 32}

Tank 32 was placed in service in 1971. Examinations of $100 \%$ of the exterior of the primary vessel wall and the annulus have shown no leakage, significant surface corrosion, or other anomalies.

\section{Tank 33}

Tank 33 was placed in service in 1969. Examinations of $100 \%$ of the exterior of the primary vessel wall and the annulus have shown no leakage, significant surface corrosion, or other anomalies.

\section{Tank 34}

Tank 34 was placed in service in 1972. Examinations of $100 \%$ of the exterior of the primary vessel wall and the annulus have shown no leakage, significant surface corrosion, or other anomalies.

\section{Tank 35}

Tank 35 was placed in service in 1977. Examinations of $100 \%$ of the exterior of the primary vessel wall and the annulus have shown no leakage, significant surface corrosion, or other anomalies. Ultrasonic thickness measurements made in 1977, 1981, and 1985 showed no detectable thinning of the tank wall.

\section{Tank 36}

Tank 36 was placed in service in 1977. Examinations of $100 \%$ of the exterior of the primary vessel wall and the annulus have shown no leakage, significant surface corrosion, or other anomalies. Ultrasonic thickness measurements made in 1977, 1981 , and 1985 showed no detectable thinning of the tank wall.

\section{Tank 37}

Tank 37 was placed in service in 1978. Examinations of $100 \%$ of the exterior of the primary vessel wall and the annulus have shown no leakage, significant surface corrosion, or other anomalies. Ultrasonic thickness measurements made in 1977 , 1981 , and 1985 showed no detectable thinning of the tank wall.

\section{Tank 38}

Tank 38 was placed in service in 1981. Examinations of $100 \%$ of the exterior of the primary vessel wall and the annulus have shown no leakage, significant surface corrosion, or other anomalies. Ultrasonic thickness measurements made in 1980, 1981 , and 1984 showed no detectable thinning of the tank wall.

\section{Tank 39}

Tank 39 was placed in service in 1982. Examinations of $100 \%$ of the exterior of the primary vessel wall and the annulus have shown no leakage, 
significant surface corrosion, or other anomalies. Ultrasonic thickness measurements made in 1980, 1981,1984 , and 1985 showed no detectable thinning of the tank wall.

\section{Tank 40}

Tank 40 was placed in service in 1986. Examinations of $100 \%$ of the exterior of the primary vessel wall and the annulus have shown no leakage, significant surface corrosion, or other anomalies. Ultrasonic thickness measurements made in 1980, 1981, 1984, and 1996 showed no service-induced corrosion.

\section{Tank 41}

Tank 41 was placed in service in 1982. Examinations of $100 \%$ of the exterior of the primary vessel wall and the annulus have shown no leakage, significant surface corrosion, or other anomalies. Ultrasonic thickness measurements made in 1980, 1981 , and 1984 showed no detectable thinning of the tank wall.

\section{Tank 42}

Tank 42 was placed in service in 1982. Examinations of $100 \%$ of the exterior of the primary vessel wall and the annulus have shown no leakage, significant surface corrosion, or other anomalies. Ultrasonic thickness measurements made in 1980 , 1981, 1984, 1985, 1990, 1995, and 1996 showed no service-induced corrosion.

\section{Tank 43}

Tank 43 was placed in service in 1982. Examinations of $100 \%$ of the exterior of the primary vessel wall and the annulus have shown no leakage, significant surface corrosion, or other anomalies. Ultrasonic thickness measurements made in 1980 , 1981, 1984, and 1985 showed no detectable thinning of the tank wall.

\section{Tank 44}

Tank 44 was placed in service in 1982. Examinations of $100 \%$ of the exterior of the primary vessel wall and the annulus have shown no leakage, significant surface corrosion, or other anomalies. Ultrasonic thickness measurements made in 1980, 1981, and 1984 showed no detectable thinning of the tank wall.

\section{Tank 45}

Tank 45 was placed in service in 1982. Examinations of $100 \%$ of the exterior of the primary vessel wall and the annulus have shown no leakage, significant surface corrosion, or other anomalies. Ultrasonic thickness measurements made in 1980, 1981 , and 1984 showed no detectable thinning of the tank wall.

\section{Tank 46}

Tank 46 was placed in service as an emergency spare tank in 1980. It was placed in waste storage service in 1994 when it began receiving concentrate from the $2 \mathrm{~F}$ evaporator. Examinations of $100 \%$ of the exterior of the primary vessel wall and the annulus have shown no significant surface corrosion or other anomalies. Ultrasonic thickness measurements made in 1980, 1981, and 1984 showed no detectable thinning of the tank wall.

\section{Tank 47}

Tank 47 was placed in service in 1980. Examinations of $100 \%$ of the exterior of the primary vessel wall and the annulus have shown no leakage, significant surface corrosion, or other anomalies. Ultrasonic thickness measurements made in 1980 , 1981, and 1984 showed no detectable thinning of the tank wall.

\section{Tank 48}

Tank 48 was placed in service in 1983. Examinations of $100 \%$ of the exterior of the primary vessel wall and the annulus have shown no leakage, significant surface corrosion, or other anomalies. Ultrasonic thickness measurements made in 1982, 1994, 1995, 1996, and 1997 showed no service-induced corrosion.

\section{Tank 49}

Tank 49 was placed in service in 1983. Examinations of $100 \%$ of the exterior of the primary vessel wall and the annulus have shown no leakage, significant surface corrosion, or other anomalies. Ultrasonic thickness measurements made in 1982, prior to placing the tank in service, and again in 1995 using the P-scan System to provide reference measurements for the future.

\section{Tank 50}

Tank 50 was placed in service in 1983. Examinations of $100 \%$ of the exterior of the primary vessel wall and the annulus have shown no leakage, significant surface corrosion, or other anomalies. Ultrasonic thickness measurements made in 1982, 1994, and 1995 showed no service-induced corrosion. 
WSRC-TR-2000-00067

Annual Waste Tank

Inspection Program - 1999

\section{Tank 51}

Tank 51 was placed in service in 1986.

Examinations of $100 \%$ of the exterior of the primary vessel wall and the annulus have shown no leakage, significant surface corrosion, or other anomalies. Ultrasonic thickness measurements made in 1982, 1996, and 1997 showed no service-induced corrosion. 
WSRC-TR-2000-00067 Annual Waste Tank

This page intentionally left blank. 


\section{Appendix A-Waste Tanks at SRS}

SRS Waste Tank Specifications

\begin{tabular}{lccccc} 
Number & Location & Trpe & $\begin{array}{c}\text { Project } \\
\text { Number }\end{array}$ & $\begin{array}{c}\text { Construction } \\
\text { Period }\end{array}$ & $\begin{array}{c}\text { Type of } \\
\text { Construction* }\end{array}$ \\
\hline $1-8$ & F & I & 8980 & $1951-1953$ & Double wall-cooled \\
$9-12$ & H & I & 8980 & $1951-1953$ & Double wall-cooled \\
$13-16$ & H & II & 8980 & $1955-1956$ & Double wall-cooled \\
$17-20$ & F & IV & 981031 & 1958 & Single wall-uncooled \\
$21-24$ & H & IV & 981089 & 1962 & Single wall-uncooled \\
$25-28$ & F & IIIA & 951493 & $1975-1978$ & Double wall-cooled \\
$29-32$ & H & III & 981232 & $1967-1970$ & Double wall-cooled \\
$33-34$ & F & III & 950974 & $1969-1972$ & Double wall-cooled \\
$35-37$ & H & IIIA & 951463 & $1974-1977$ & Double wall-cooled \\
& & & $(74-1-\mathrm{a})$ & & \\
$38-43$ & H & IIIA & 951618 & $1976-1980$ & Double wall-cooled \\
$44-47$ & F & IIIA & 951747 & $1977-1980$ & Double wall-cooled \\
$48-51$ & H & IIIA & 951828 & $1978-1981$ & Double wall-cooled
\end{tabular}

* Tanks 32 and 35 have removable, roof-supported cooling coils. Tanks 30, 33, and 34 have bottom-supported deployable cooling coils. Tanks 29 and 31 have some deployable and some close-packed cooling assemblies, all bottom-supported. All other cooled tanks have permanently installed cooling coils, roof-supported in Type I and II and bottom-supported in Type III tanks. 
This page intentionally left blank. 


\section{Appendix B-Summary of 1999 Inspections}

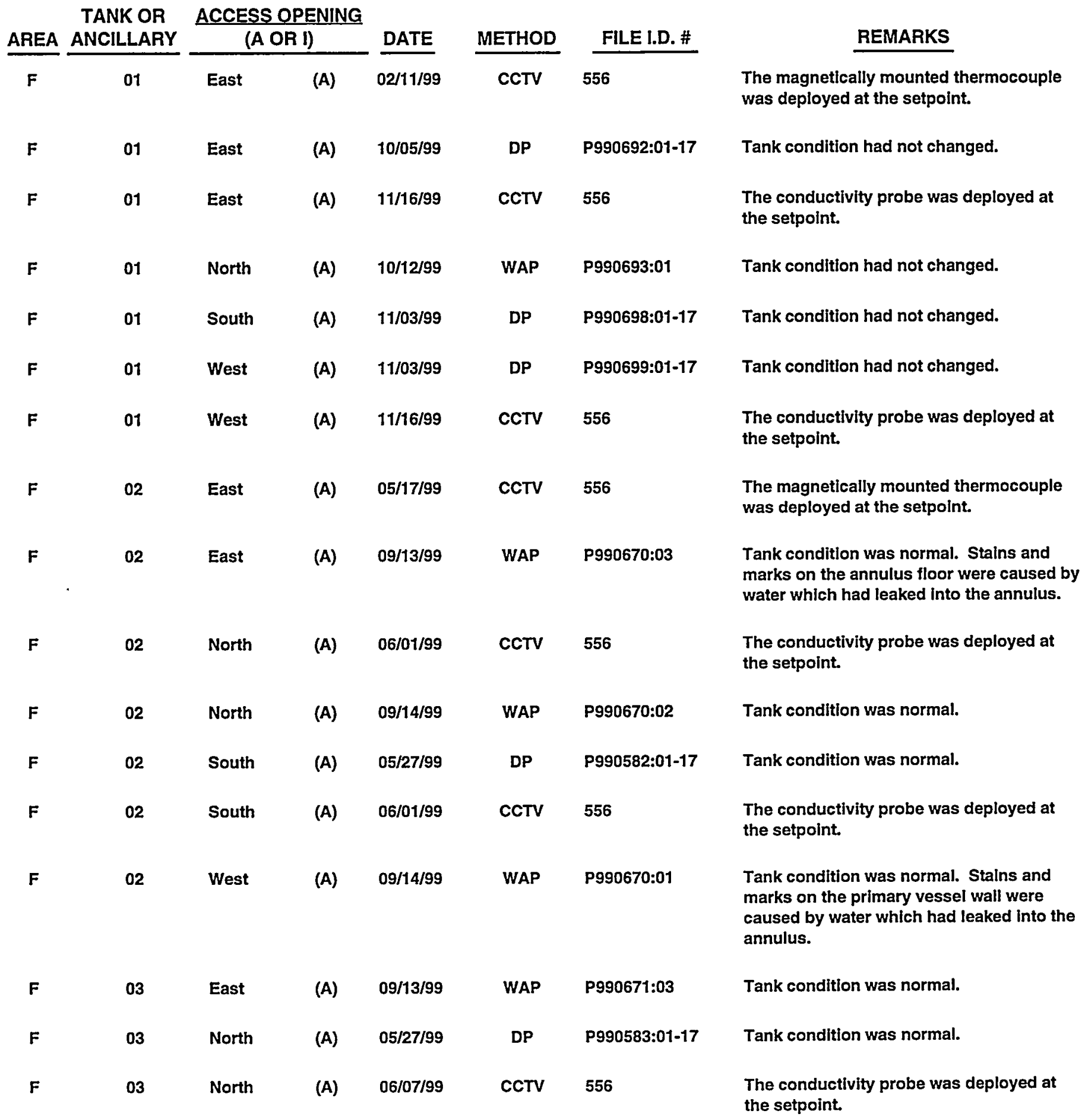

(A) = annulus; BFV = back flush valve; CCTV = closed circuit television; CCWS = chromate cooling water system; COP = clean out port; CTS = concentrate transfer system; CWT = concentrated waste tank; DB = diversion box; DP = direct photography; ERIP = encasement riser inspection port; ETF = effluent treatment facility; EVAP = evaporator; GDL = gravity drain line; HELIUM = helium leak test; HLLCP = high llquid level conductivity probe; $(I)=$ interior; ITPFC = in-tank precipitation filter cell; JB = junction box; LDB = leak detection box; LPPP = low point pump pit; LPS = leak probe sleeve; $M L D B=$ modified leak detection box; $P P=$ pump pit; $P S P=$ periscopic photography; RCP = reinforced concrete pipe; SWS = storm water sewer; UT = ultrasonic test; VB = valve box; VP = video photograph; $W A P=$ wide angle photography; $W L E=$ waste line encasement 
TANK OR ACCESS OPENING

\begin{tabular}{|c|c|c|c|c|c|c|}
\hline AREA & ANCILLARY & (A & ) & DATE & METHOD & FILE I.D.\# \\
\hline $\mathbf{F}$ & 03 & South & (A) & $06 / 07 / 99$ & CCTV & 556 \\
\hline $\mathbf{F}$ & 03 & South & (A) & $09 / 13 / 99$ & WAP & P990671:01 \\
\hline $\mathbf{F}$ & 03 & West & (A) & $06 / 07 / 99$ & cCTV & 556 \\
\hline $\mathbf{F}$ & 03 & West & (A) & $09 / 13 / 99$ & WAP & P990671:02 \\
\hline $\mathbf{F}$ & 04 & VB & & 07/28/99 & ccrv & 559 \\
\hline $\mathbf{F}$ & 04 & VB & & 07/28/99 & cctv & 559 \\
\hline $\mathbf{F}$ & 04 & East & (A) & $06 / 01 / 99$ & CCTV & 556 \\
\hline $\mathbf{F}$ & 04 & East & (A) & $09 / 14 / 99$ & WAP & P990672:03 \\
\hline $\mathbf{F}$ & 04 & North & (A) & $06 / 01 / 99$ & CCTV & 556 \\
\hline$F$ & 04 & North & (A) & $09 / 14 / 99$ & WAP & P990672:02 \\
\hline$F$ & 04 & South & (A) & $06 / 01 / 99$ & CCTV & 556 \\
\hline $\mathbf{F}$ & 04 & South & (A) & $09 / 14 / 99$ & WAP & P990672:01 \\
\hline$F$ & 04 & West & (A) & $05 / 27 / 99$ & DP & P990584:01-17 \\
\hline$F$ & 05 & VB & & 07/28/99 & cctV & 559 \\
\hline$F$ & 05 & VB & & $07 / 28 / 99$ & CCTV & 559 \\
\hline $\boldsymbol{F}$ & 05 & East & (A) & 09/13/99 & WAP & P990673:03 \\
\hline
\end{tabular}

$\mathbf{F}$

$\mathbf{F}$

05

South
(A)

06/07/99

CCTV

556

(A) $\quad 09 / 13 / 99$

WAP

P990673:02

DP

P990585:01-17

\section{REMARKS}

The conductivity probe was deployed at the setpoint.

Tank condition was normal.

The magnetically mounted thermocouple was deployed at the setpoint.

Tank condition was normal.

The conductivity probe was deployed at the setpoint.

The conductivity probe was deployed at the setpoint.

The magnetically mounted thermocouple was deployed at the setpolnt.

Tank condition was normal.

The conductivity probe was deployed at the setpoint.

Tank condition was normal.

The conductivity probe was deployed at the setpoint.

Tank condition was normal.

Tank condition was normal.

The conductivity probe was deployed at the setpoint.

The conductivity probe was deployed at the setpoint.

Tank condition was normal. Stains and marks on the primary vessel wall were caused by water which had leaked In the annulus.

The conductivity probe was deployed at the setpoint.

Tank condition was normal.

Tank condition was normal. Stains and marks on the annulus floor were caused by water which had leaked into the annulus.

The conductivity probe was deployed at the setpoint. 


\begin{tabular}{|c|c|c|c|c|c|c|c|}
\hline AREA & $\begin{array}{l}\text { TANK OR } \\
\text { ANCILLARY }\end{array}$ & $\frac{\text { ACCESS }}{(A)}$ & ENING & DATE & METHOD & FILE I.D. \# & REMARKS \\
\hline $\mathbf{F}$ & 05 & West & (A) & $06 / 08 / 99$ & CCTV & 556 & $\begin{array}{l}\text { The magnetically mounted thermocouple } \\
\text { was deployed at the setpoint. }\end{array}$ \\
\hline F & 05 & West & (A) & $09 / 13 / 99$ & WAP & P990673:01 & $\begin{array}{l}\text { Tank condition was normal. An increase of } \\
\text { stains and marks on the primary vessel } \\
\text { wall were caused by water which had } \\
\text { leaked into the annulus. }\end{array}$ \\
\hline $\mathbf{F}$ & 05 & Center & (I) & $06 / 19 / 99$ & CCTV & 590 & $\begin{array}{l}\text { Monitored and documented steel taping } \\
\text { performed via riser } 6 \text { and the center rlser to } \\
\text { observe for dusting and determine } \\
\text { uniformity of sludge level. No dusting was } \\
\text { observed. }\end{array}$ \\
\hline $\mathbf{F}$ & 06 & VB & & $07 / 28 / 99$ & CCTV & 559 & $\begin{array}{l}\text { The conductivity probe was deployed at } \\
\text { the setpoint. }\end{array}$ \\
\hline $\mathbf{F}$ & 06 & VB & & $07 / 28 / 99$ & CCTV & 559 & $\begin{array}{l}\text { The conductivity probe was deployed at } \\
\text { the setpoint. }\end{array}$ \\
\hline $\boldsymbol{F}$ & 06 & East & (A) & $06 / 08 / 99$ & CCTV & 556 & $\begin{array}{l}\text { The magnetically mounted thermocouple } \\
\text { was deployed at the setpoint. }\end{array}$ \\
\hline $\mathbf{F}$ & 06 & East & (A) & $09 / 13 / 99$ & WAP & P990674:03 & Tank condition was normal. \\
\hline $\mathbf{F}$ & 06 & North & (A) & $06 / 08 / 99$ & CCTV & 556 & $\begin{array}{l}\text { The conductivity probe was deployed at } \\
\text { the setpoint. }\end{array}$ \\
\hline $\mathbf{F}$ & 06 & North & (A) & $09 / 13 / 99$ & WAP & P990674:02 & Tank condition was normal. \\
\hline $\mathbf{F}$ & 06 & South & (A) & $06 / 08 / 99$ & CCTV & 556 & $\begin{array}{l}\text { The conductivity probe was deployed at } \\
\text { the setpoint. }\end{array}$ \\
\hline $\mathbf{F}$ & 06 & South & (A) & $09 / 13 / 99$ & WAP & P990674:01 & Tank condition was normal. \\
\hline $\mathbf{F}$ & 06 & West & (A) & $05 / 27 / 99$ & DP & P990586:01-17 & Tank condition was normal. \\
\hline $\mathbf{F}$ & 07 & LDB-01 & & $01 / 22 / 99$ & CCTV & 554 & $\begin{array}{l}\text { The conductivity probe was deployed at } \\
\text { the setpoint. }\end{array}$ \\
\hline $\mathbf{F}$ & 07 & LDB-02 & & $01 / 22 / 99$ & CCTV & 554 & $\begin{array}{l}\text { The conductivity probe was deployed at } \\
\text { the setpoint. }\end{array}$ \\
\hline $\mathbf{F}$ & 07 & LDB-A & & $05 / 26 / 99$ & CCTV & 554 & $\begin{array}{l}\text { The conductivity probe was deployed at } \\
\text { the setpoint. }\end{array}$ \\
\hline $\boldsymbol{F}$ & 07 & LDB-B & & $05 / 26 / 99$ & CCTV & 554 & The conductivity probe was not observed. \\
\hline $\mathbf{F}$ & 07 & VB & & $07 / 28 / 99$ & CCTV & 559 & $\begin{array}{l}\text { The conductivity probe was deployed at } \\
\text { the setpoint. }\end{array}$ \\
\hline $\mathbf{F}$ & 07 & VB & & $07 / 28 / 99$ & cctV & 559 & $\begin{array}{l}\text { The conductivity probe was deployed at } \\
\text { the setpoint. }\end{array}$ \\
\hline
\end{tabular}




\begin{tabular}{|c|c|c|c|c|c|c|c|}
\hline AREA & $\begin{array}{l}\text { TANK OR } \\
\text { ANCILLARY } \\
\end{array}$ & $\begin{array}{r}\text { ACCESS O } \\
\text { (A OF }\end{array}$ & ENING & DATE & METHOD & FILE I.D. \# & REMARKS \\
\hline $\boldsymbol{F}$ & 07 & VB-1 & & 09/09/99 & CCTV & 559 & $\begin{array}{l}\text { Inspection of the drain line revealed that } \\
\text { the drain line was free of obstructions; } \\
\text { however, approximately two to three } \\
\text { inches of mud had accumulated at the welr. }\end{array}$ \\
\hline $\mathbf{F}$ & 07 & VB-2 & & $09 / 02 / 99$ & CCTV & 559 & $\begin{array}{l}\text { Inspection of the drain line revealed that } \\
\text { the drain line was free of obstructions; } \\
\text { however, approximately two to three } \\
\text { inches of mud had accumulated at the welr. }\end{array}$ \\
\hline $\mathbf{F}$ & 07 & VB-3 & & $09 / 02 / 99$ & CCTV & 559 & $\begin{array}{l}\text { Inspection of the drain line revealed that } \\
\text { the drain line was free of obstructions; } \\
\text { however, approximately two to three } \\
\text { inches of mud had accumulated at the weir. }\end{array}$ \\
\hline $\mathbf{F}$ & 07 & VB-4 & & $09 / 09 / 99$ & CCTV & 559 & $\begin{array}{l}\text { Inspection of the drain line revealed that } \\
\text { the drain line was free of obstructlons; } \\
\text { however, approximately two to three } \\
\text { Inches of mud had accumulated at the weir. }\end{array}$ \\
\hline $\mathbf{F}$ & 07 & VB-5 & & $09 / 09 / 99$ & CCTV & 559 & $\begin{array}{l}\text { Inspection of the drain line revealed that } \\
\text { the drain line was free of obstructions; } \\
\text { however, approximately two to three } \\
\text { inches of mud had accumulated at the weir. }\end{array}$ \\
\hline $\mathbf{F}$ & 07 & North & (A) & $05 / 27 / 99$ & DP & P990587:01-17 & Tank condition was normal. \\
\hline $\mathbf{F}$ & 07 & North & (A) & $06 / 08 / 99$ & $\operatorname{cctV}$ & 556 & $\begin{array}{l}\text { The conductivity probe was deployed at } \\
\text { the setpoint. }\end{array}$ \\
\hline $\mathbf{F}$ & 07 & South & (A) & $06 / 08 / 99$ & CCTV & 556 & $\begin{array}{l}\text { The conductivity probe was deployed at } \\
\text { the setpoint. }\end{array}$ \\
\hline $\mathbf{F}$ & 07 & South & (A) & $09 / 13 / 99$ & WAP & P990675:01 & Tank condition was normal. \\
\hline $\mathbf{F}$ & 07 & West & (A) & $06 / 08 / 99$ & CCTV & 556 & $\begin{array}{l}\text { The magnetically mounted thermocouple } \\
\text { was deployed at the setpoint. }\end{array}$ \\
\hline $\mathbf{F}$ & 07 & West & (A) & $09 / 13 / 99$ & WAP & P990675:02 & Tank condition was normal. \\
\hline$F$ & 07 & 01 & (l) & $07 / 21 / 99$ & CCTV & 601 & Documented riser equipment \\
\hline $\mathbf{F}$ & 07 & 07 & (l) & $07 / 21 / 99$ & CCTV & 601 & Documented riser equipment \\
\hline $\mathbf{F}$ & 07 & Center & (l) & $07 / 21 / 99$ & CCTV & 601 & Documented riser equipment \\
\hline $\mathbf{F}$ & 07 & Center & (l) & $11 / 04 / 99$ & CCTV & 602 & $\begin{array}{l}\text { Documented tank contents. No unusual } \\
\text { conditions were observed. }\end{array}$ \\
\hline $\mathbf{F}$ & 08 & Flush Box & & $08 / 23 / 99$ & cCTV & 554 & $\begin{array}{l}\text { The conductivity probe was deployed at } \\
\text { the setpoint. }\end{array}$ \\
\hline $\mathbf{F}$ & 08 & Flush Box & & $11 / 05 / 99$ & CCTV & 554 & $\begin{array}{l}\text { Determined the length of the conductivity } \\
\text { probe standpipes for proper installation of } \\
\text { the conductivity probes. }\end{array}$ \\
\hline
\end{tabular}


TANK OR ACCESS OPENING

\begin{tabular}{|c|c|c|c|c|c|c|}
\hline AREA & ANCILLARY & (A Of & l) & DATE & METHOD & FILE I.D. \# \\
\hline $\mathbf{F}$ & 08 & $\begin{array}{l}\text { Spray } \\
\text { Chamber }\end{array}$ & & $08 / 23 / 99$ & cctV & 554 \\
\hline $\mathbf{F}$ & 08 & VB & & 07/28/99 & CCTV & 559 \\
\hline $\mathbf{F}$ & 08 & East & (A) & 06/08/99 & CCTV & 556 \\
\hline $\mathbf{F}$ & 08 & East & (A) & 09/13/99 & WAP & P990676:03 \\
\hline $\mathbf{F}$ & 08 & East & (A) & 09/15/99 & CCTV & 556 \\
\hline $\mathbf{F}$ & 08 & North & (A) & 06/08/99 & CCTV & 556 \\
\hline $\mathbf{F}$ & 08 & North & (A) & 09/13/99 & WAP & P990676:02 \\
\hline $\mathbf{F}$ & 08 & South & (A) & 05/27/99 & DP & P990588:01-17 \\
\hline $\mathbf{F}$ & $0 B$ & South & (A) & 06/08/99 & CCTV & 556 \\
\hline $\mathbf{F}$ & 08 & West & (A) & 09/13/99 & WAP & P990676:01 \\
\hline$F$ & 08 & 01 & (l) & $02 / 11 / 99$ & CCTV & 549 \\
\hline
\end{tabular}

$\mathbf{F}$

08

01

(l)

$02 / 16 / 99$

CCTV

549

$\mathbf{F}$

OB

01

(I)

$02 / 18 / 99$

CCTV

08

02

(l) $10 / 02 / 99$

CCTV

615

$\begin{array}{llllll}08 & 02 & \text { (I) } & 10 / 02 / 99 & \text { CCTV } & 615\end{array}$

\section{REMARKS}

The conductivity probe was deployed at the setpoint.

The conductivity probe was deployed at the setpoint.

The magnetically mounted thermocouple was deployed at the setpoint.

Tank condition was normal.

The magnetically mounted thermocouple was deployed at the setpoint.

The conductivity probe was deployed at the setpoint.

Tank condition was normal. A masselln cloth was observed on top of the annulus steel pan near the annulus jet.

Tank condition was normal. Stains and marks on the primary vessel wall were caused by water which had leaked into the annulus.

The conductivity probe was deployed at the setpoint.

Tank condition was normal.

Provided video support for mechanical removal of a metal bar attached to a cooling coil. The Inspection verified removal of the bar cleared the space beneath the riser for pump installation.

Provided video support for the mechanical remote removal of a metal plate approximately 2" $\times 2$ " attached to the bottom of the riser sleeve. Inspection verified removal of the plate gave adequate clearance for pump installation.

Provided video support for guiding mechanical shaping of riser and verified the riser dimensions were adequate to permit installation of a pump.

Observed for obstructions beneath slurry pump \#1 as it was raised. No obstructions were observed, and the discharge was clean and free of pluggage. 
TANK OR ACCESS OPENING

\begin{tabular}{|c|c|c|c|c|c|c|}
\hline AREA & ANCILLARY & & & DATE & METHOD & FILE I.D. \# \\
\hline$F$ & 08 & 02 & (I) & $10 / 07 / 99$ & CCTV & 624 \\
\hline$F$ & 08 & 02 & (I) & 12/15/99 & CCTV & 624 \\
\hline$F$ & 08 & 02 & (l) & $12 / 15 / 99$ & CCTV & 624 \\
\hline$F$ & 08 & 03 & (l) & 02/03/99 & CCTV & 549 \\
\hline
\end{tabular}

F

08

04

(l)

05/03/99

CCTV

580

$\mathbf{F}$

08

04

(l)

05/11/99

CCTV

582

$\mathbf{F}$

08

04

(l)

06/02/99

CCTV

580

$F$

08

04

(i)

09/08/99

CCTV

615

F

08

04

(I)

$10 / 07 / 99$

CCTV

624

$F$

F

08

08

06

06

$F$

08

08

(I)

$01 / 14 / 99$

CCTV

549

$$
\text { F }
$$

08

08

(l) $01 / 19 / 99$

CCTV

549

\section{REMARKS}

Determined that there was no obstruction that could have prevented rotation of pump \#3. However, the pump was impacted into the sludge.

Determined the direction of dlscharge from the slurry pump in Riser 1.

Determined the directlon of discharge from the slurry pump in Riser 3.

Provided video support for the mechanical removal of obstructions and determining the riser dimension was adequate to permit installation of a pump.

Provided video support for the flushing of the transfer jet. During the flushing of the discharge side, material which appeared to be sludge was washed down to the intake screen.

Monitored and documented water flow through the jet.

Inspection revealed no obstructions that would interfere with the installation of a cradle in the center riser.

Inspection of reel tape revealed the reel tape probe was not centered in the standpipe allowing the probe to get caught on the outer edge of the riser liner during cycling. Reel tape was repositioned for proper function.

Determined that there was no obstruction that could have prevented rotation of pump \#3. However, the pump was impacted into the sludge.

Monitored flushing of the transfer jet.

Determined and documented that no obstruction existed beneath riser 6 . Documented the installation of a slurry pump.

Assisted with guiding mechanical shaping of riser and verifled the riser dimensions were adequate to permit installation of a pump.

Assisted with guiding mechanical shaping of riser and verified the riser dimensions were adequate to permit installation of a pump. 
TANK OR ACCESS OPENING AREA ANCILLARY

F

08

08 (A OR I)

08

South

(A)

(I)

DATE

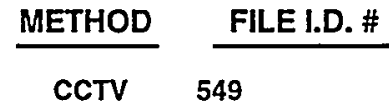

H

09

09

South

(A)

09/23/99

DP

P990678:01-17

H

H

H

H

H

H

H

10

East

(A)

07/20/99

CCTV

NA

H

H

10

East

H

10

East

(A)

$09 / 23 / 99$

DP

P990679:01-17
REMARKS

Assisted with guiding mechanical shaping of riser and verified the riser dimensions were adequate to permit installation of a pump.

The conductivity probe was deployed at the setpoint.

Tank condition had not changed. Water had leaked into the annulus and reconfigured the surface of the leaked waste in the annulus pan.

Assisted in moving the conductivity probe out of the waste to clear the alarm.

The conductivity probe and magnetically mounted thermocouple were deployed at the setpoint.

Tank condition had not changed. Water had leaked into the annulus and reconfigured the surface of the leaked waste in the annulus pan.

Documented positioning the conductivity probe on the MLDB tloor.

The conductivity probe was deployed at the setpoint.

Assisted with positioning a new conductivity probe in the annulus at the setpoint.

Assisted with positioning the magnetically mounted thermocouple. The thermocouple could not be positioned due to tangled wires.

The magnetically mounted thermocouple was deployed at the setpoint.

Assisted with positloning a new magnetically mounted thermocouple at the setpoint.

Tank condition had not changed. Water had leaked into the annulus and reconfigured the surface of the leaked waste in the annulus pan.

Assisted with positioning a new conductivity probe in the annulus at the setpoint. 


\section{TANK OR ACCESS OPENING}

AREA ANCILLARY

H

10

North

(A)

DATE

$06 / 17 / 9$

METHOD

DP

FILE I.D. \#

P990629:01-17

H

10

West

(A)

09/01/99

WAP

P990666:01

H

11

East

(A)

04/06/99

CCTV

571

H

11 East

(A)

05/17/99

CCTV

571

H

11

East

(A)

09/01/99

WAP

P990667:02

H

11

North

(A)

03/16/99

CCTV

556

H

11

North

(A)

03/17/99

CCTV

571

H

11

North

(A)

04/05/99

CCTV

571

H

11

North

(A)

05/19/99

CCTV

571

H

H

$\begin{array}{lrr}H & 11 & \text { North } \\ H & 11 & \text { South }\end{array}$

(A)

(A)

03/17/99
WAP

CCTV $\quad 556$

\section{REMARKS}

Tank condition had not changed. The leaked waste on the annulus floor had been reconflgured by rainwater whlch had leaked into the annulus.

Tank condition had not changed.

Examination and documentation was performed of the pan surfaces where nodules were found. The nodules were potential indications of pan steel corrosion or innocuous deposits formed by inleakage and dripping from above.

Documented areas of potential surface corrosion observed on the ventilation duct and annulus floor pan.

Tank condition had not changed. An increase in stains on the annulus floor was caused by condensate falling from the annulus cover plates.

Assisted In deployment of the conductlvity probe. The probe was placed in a holder to position it 1.5 inches above the pan floor. The holder was placed on the floor between the ventilation duct and the tank primary vessel wall.

Documented deposits on the surface of the secondary containment pan whlch Indlcate the possibility of corrosion through the pan wall.

Examination and documentation was performed of the pan surfaces where nodules were found. The nodules were potentlal indications of pan steel corrosion or innocuous deposits formed by Inleakage and dripping from above.

Examination and documentation was performed of the pan surfaces where nodules were found. The nodules were potential indications of pan steel corrosion or are innocuous deposits formed by inleakage and dripping from above.

Tank condition had not changed.

Assisted in deployment of the conductivity probe. The probe was placed in a holder to position it 1.5 inches above the pan floor. The holder was placed on the floor between the ventilation duct and the tank primary vessel wall. 


\begin{tabular}{|c|c|c|c|c|c|c|c|}
\hline \multirow{2}{*}{$\frac{\text { AREA }}{\mathrm{H}}$} & \multirow{2}{*}{$\begin{array}{c}\text { TANK OR } \\
\text { ANCILLARY } \\
11\end{array}$} & \multicolumn{2}{|c|}{$\frac{\text { ACCESS OPENING }}{(A \text { OR I) }}$} & \multirow{2}{*}{$\frac{\text { DATE }}{03 / 17 / 99}$} & \multirow{2}{*}{$\frac{\text { METHOD }}{\text { CCTV }}$} & \multirow{2}{*}{$\frac{\text { FILE I.D. \# }}{571}$} & \multirow{2}{*}{$\begin{array}{l}\text { REMARKS } \\
\text { Documented deposits on the surface of the } \\
\text { secondary containment pan which indicate } \\
\text { the possibility of corrosion through the pan } \\
\text { wall. }\end{array}$} \\
\hline & & South & (A) & & & & \\
\hline H & 11 & South & (A) & $04 / 06 / 99$ & CCTV & 571 & $\begin{array}{l}\text { Examination and documentation was } \\
\text { performed of the pan surfaces where } \\
\text { nodules were found. The nodules were } \\
\text { potential indications of pan steel corrosion } \\
\text { or are innocuous deposits formed by } \\
\text { inleakage and dripping from above. }\end{array}$ \\
\hline H & 11 & South & (A) & $05 / 19 / 99$ & CCTV & 571 & $\begin{array}{l}\text { Examination and documentation was } \\
\text { performed of the pan surfaces where } \\
\text { nodules were found. The nodules were } \\
\text { potential indications of pan steel corrosion } \\
\text { or are innocuous deposits formed by } \\
\text { inleakage and dripping from above. White } \\
\text { deposits were observed on the concrete } \\
\text { curb which forms a retaining ring to } \\
\text { contain the sand pad beneath the tank. } \\
\text { The white material may be dry leaked } \\
\text { waste or calciferous deposits. Sampling of } \\
\text { the deposits will be necessary to determine } \\
\text { composition. }\end{array}$ \\
\hline$H$ & 11 & South & (A) & $05 / 25 / 99$ & DP & P990589:01-17 & $\begin{array}{l}\text { Tank condition was normal. Stains and } \\
\text { marks on the primary vessel wall were } \\
\text { caused by water which had leaked into the } \\
\text { annulus. Evidence of mild surface } \\
\text { corrosion on the annulus floor was } \\
\text { observed. }\end{array}$ \\
\hline H & 11 & South & (A) & 09/03/99 & CCTV & 613 & $\begin{array}{l}\text { Inspected the annulus pan floor prior to } \\
\text { cleaning and supported the cleaning } \\
\text { activities. }\end{array}$ \\
\hline $\mathbf{H}$ & 11 & South & (A) & 09/07/99 & cctV & 613 & $\begin{array}{l}\text { Inspected the annulus floor after cleaning } \\
\text { was performed on } 09 / 03 / 99 \text {. The area } \\
\text { cleaned showed surface corrosion. No } \\
\text { deep pitting or indication of throughwall } \\
\text { penetration was found. }\end{array}$ \\
\hline H & 11 & South & (A) & $10 / 21 / 99$ & CCTV & 613 & $\begin{array}{l}\text { Observed and evaluated cleaning a small } \\
\text { area of the annulus pan floor. After } \\
\text { cleaning, observation indicated no through } \\
\text { wall penetration. Small areas where the } \\
\text { paint had flaked away showed shallow } \\
\text { corrosion of the steel surface. }\end{array}$ \\
\hline H & 11 & West & (A) & $04 / 05 / 99$ & CCTV & 571 & $\begin{array}{l}\text { Examination and documentation was } \\
\text { performed of the pan surfaces where } \\
\text { nodules were found. The nodules were } \\
\text { potential indications of pan steel corrosion } \\
\text { or innocuous deposits formed by inleakage } \\
\text { and dripping from above. }\end{array}$ \\
\hline
\end{tabular}


TANK OR ACCESS OPENING

\begin{tabular}{|c|c|c|c|c|c|c|}
\hline AREA & ANCILLARY & & & DATE & METHOD & FILE I.D.\# \\
\hline H & 11 & West & (A) & 05/17/99 & CCTV & 571 \\
\hline H & 11 & West & (A) & 05/17/99 & CCTV & 556 \\
\hline H & 11 & West & (A) & 05/25/99 & DP & P990590:01-18 \\
\hline
\end{tabular}

H $11 \quad 06$

(I) 03/10/99

CCTV

568

H

H

H

H

H

H

H

H

H

H

13

010
01/25/99

$03 / 11 / 99$
CCTV 554

WAP P990546:02
REMARKS

Examination and documentation was performed of the pan surfaces where nodules were found. The nodules were potential indications of pan steel corrosion or innocuous deposits formed by inleakage and dripping trom above.

The magnetically mounted thermocouple was deployed at the setpoint.

Tank condition was normal. Stains and marks on the primary vessel wall have increased since inspected on 3/19/97. Examination and documentation was performed of the pan surfaces where nodules were found. The nodules were potential indications of pan steel corrosion or innocuous deposits formed by inleakage and dripping from above.

Inspection of jet in riser 07 determined the elevation of the suction leg was below the liquid. The couplings were observed at the liquid level.

Tank condition had not changed.

The conductlvity probe was deployed at the setpoint.

Tank condition had not changed.

The conductivity probe was deployed at the setpoint.

Tank condition was normal. Stains and marks on the primary vessel wall were caused by water which had leaked into the annulus.

The conductivity probe was deployed at the setpoint.

Tank condition had not changed.

Monitored and documented steel taping performed via riser 6 and the center riser and to observe for dusting and determine uniformity of sludge level. No dusting was observed.

The conductivity probe was deployed at the setpoint.

Tank condition had not changed. 
TANK OR ACCESS OPENING

$\frac{\text { AREA ANCILLARY }}{H} \frac{(\text { A OR I) }}{13} \frac{\text { DATE }}{013} \quad$ (A) $\frac{\text { METHOD }}{\text { CCTV }} \quad$ FILE I.D. \#

H

13

032

(A)

$03 / 11 / 99$

WAP

P990546:03

H

13

055

(A)

$03 / 11 / 99$

WAP

P990546:04

(A) $03 / 11 / 99$

WAP

P990546:05

(A) $09 / 24 / 99$

WAP

P990685:02

(A)

03/11/99

WAP

P990546:06

H

H

H

13

228

(A)

$03 / 11 / 99$

WAP

P990546:07

H

13

East

(A)

02/16/99

DP

P990522:01-17

H

13

North

(A)

$03 / 11 / 99$

WAP

P990546:01

H

13

North

(A)

$10 / 19 / 99$

CCTV

556

H

13

North

(A)

$11 / 13 / 99$

CCTV

556

H

13

South

(A)

$09 / 24 / 99$
REMARKS

The probe in the south riser was lifted up so that it could be observed, then lowered to the floor between the ventilation duct and the secondary vessel wall. The probe was not visible where it came to rest beneath the ventilation duct.

Tank condition had not changed. Stains and marks on the primary vessel wall were caused by water which had leaked into the annulus.

Tank condition had not changed.

Tank condition had not changed.

Tank condition had not changed.

Tank condition had not changed. Stains and marks on the primary vessel wall were caused by water which had leaked into the annulus.

Tank condition had not changed.

Tank condition had not changed. Stains and marks on the primary vessel wall were caused by water which had leaked into the annulus.

Tank condition had not changed. Stalns, marks and deposits on the primary vessel wall were caused by water which had leaked into the annulus.

Tank condition had not changed. Stains and marks on the primary vessel wall were caused by water which had leaked into the annulus.

Tank condition had not changed. Stains and marks on the primary vessel wall were caused by water which had leaked into the annulus.

The conductivity probe and the magnetically mounted thermocouple were deployed at the setpoint.

The conductivity probe and the magnetically mounted thermocouple were deployed at the setpoint.

Tank condition had not changed. Stains and marks on the primary vessel wall indicated that water continued to leak into the annulus. 
TANK OR ACCESS OPENING

\begin{tabular}{|c|c|c|c|c|c|c|}
\hline AREA & ANCILLARY & \multicolumn{2}{|c|}{ (A OR I) } & DATE & METHOD & FILE I.D. \# \\
\hline H & 13 & South & (A) & 10/19/99 & CCTV & 556 \\
\hline H & 13 & West & (A) & $02 / 16 / 99$ & DP & P990523:01-17 \\
\hline H & 14 & 013 & (A) & $02 / 16 / 99$ & DP & P990515:01-16 \\
\hline
\end{tabular}

H

14

032

(A)

$09 / 24 / 99$

WAP

P990686:01

H

14

065

(A)

$09 / 24 / 99$

WAP

P990686:02

H

14

108

(A)

09/24/99

WAP

P990686:03

H

(A)

$02 / 16 / 99$

DP

P990516:01-15

H

14

125

(A)

$09 / 24 / 99$

WAP

P990686:04

H

14

151
(A) $02 / 16 / 99$
DP

P990517:01-17

\section{REMARKS}

The conductivity probe was deployed at the setpoint.

Tank condition had not changed.

Tank condition had not changed. Stains, marks and calciferous deposits on the primary vessel wall were caused by water which had leaked into the annulus. A nodule of leaked waste at a crack site adjacent to the bottom girth weld had fallen off of the primary vessel wall. The surface of leaked waste in the annulus had been reconfigured by water which had leaked into the annulus.

Tank condition had not changed. Stains and marks on the primary vessel wall have increased since inspected on 3/10/97 Indicating water continued to leak into the annulus.

Tank condition had not changed. Water had leaked into the annulus and reconfigured the surface of the leaked waste in the annulus pan.

Tank condition had not changed. Water had leaked into the annulus and reconfigured the surface of the leaked waste in the annulus pan.

Tank condition had not changed. Stalns and marks on the primary vessel wall were caused by water which had leaked into the annulus. Small areas of mild surface corrosion were observed on the primary vessel wall above the bottom girth weld. The surface of the leaked waste in the annulus had been reconfigured by rainwater which had leaked into the annulus.

Tank condition had not changed. Water had leaked into the annulus and reconflgured the surface of the leaked waste in the annulus pan.

Tank condition had not changed. Stalns and marks on the primary vessel wall were caused by water which had leaked into the annulus. Small areas of mild surface corrosion were observed on the primary vessel wall. The surface of leaked waste in the annulus had been recontigured by water which had leaked into the annulus. A small nodule of leaked waste had fallen off of the primary vessel wall. 


\begin{tabular}{|c|c|c|c|c|c|c|}
\hline AREA & $\begin{array}{c}\text { TANK OR } \\
\text { ANCILLARY } \\
\end{array}$ & ACCE & ENING & DATE & METHOD & FILE I.D. \# \\
\hline H & 14 & 170 & (A) & $02 / 16 / 99$ & DP & P990518:01-17 \\
\hline H & 14 & 207 & (A) & $02 / 16 / 99$ & DP & P990519:01-17 \\
\hline H & 14 & 235 & (A) & $02 / 16 / 99$ & DP & P990520:01-17 \\
\hline H & 14 & 259 & (A) & $02 / 16 / 99$ & DP & P990521:01-17 \\
\hline H & 14 & East & (A) & $02 / 16 / 99$ & DP & P990514:01-17 \\
\hline H & 14 & East & (A) & $04 / 26 / 99$ & CCTV & 556 \\
\hline
\end{tabular}

Tank condition had not changed. Stains and marks on the primary vessel wall were caused by water which had leaked into the annulus. The surface of the leaked waste in the annulus had been recontigured by water which had leaked into the annulus. Calciferous deposits on the primary vessel wall had been washed away by water which had leaked into the annulus and cascaded down the wall.

Tank condition had not changed. Stains and marks on the primary vessel wall were caused by water which had leaked into the annulus. The surface of the leaked waste in the annulus had been reconfigured by water which had leaked into the annulus.

Tank condition had not changed. Stains and marks on the primary vessel wall were caused by water which had leaked into the annulus. The surface of the leaked waste in the annulus had been reconfigured by water which had leaked into the annulus. A nodule of leaked waste has fallen off of the tank wall and two leak sites showed evidence of additional seepage from the tank since inspected on 03/10/97.

Tank condition had not changed. Stains and marks on the primary vessel wall were caused by water which had leaked into the annulus and the surface of the leaked waste in the annulus had been reconfigured by water which had leaked into the annulus.

The probe was lifted up so that it could be observed, then lowered to the floor between the ventllation duct and the secondary vessel wall. The probe was not visible where it came to rest beneath the ventilation duct.

Tank condition had not changed. The surface of the leaked waste in the annulus had been reconfigured by water which had leaked into the annulus. 
TANK OR ACCESS OPENING

$\frac{\text { AREA }}{H} \frac{\text { ANCILLARY }}{14} \frac{\frac{(A \text { OR I) }}{\text { North }} \quad \text { (A) } \frac{\text { DATE }}{04 / 26 / 99} \quad \frac{\text { METHOD }}{\text { CCTV }} \quad \text { FILE I.D. \# }}{556}$

H

15

010

(A)

$09 / 23 / 99$

(A)

$10 / 21 / 99$

$15 \quad 010$

H

15

032

H

15

055

(A)

$03 / 29 / 99$

WAP

P990547:06

H

15

071

15

107

H

H

15

107

(A)

$10 / 25 / 99$

(A)

03/29/99

(A) $09 / 23 / 99$

WAP

P990547:05

DP $\quad$ P990680:01-17

CCTV

556

H

H

15

137

(A)

09/23/99

(A)

$09 / 23 / 9$

(A)

09/23/99

(A)

$07 / 15 / 99$

207

H

15

(A)

(1)

\section{REMARKS}

Inspection verified that the conductivity probe was approximately 1-2 Inches above the leaked waste, hanging vertically with the bottom extending below the top of the ventilation duct. The magnetically mounted thermocouple was deployed at the setpoint.

Tank condition had not changed.

The probe in the south riser was llfted up so that it could be observed, then lowered to the floor between the ventilation duct and the secondary vessel wall. The probe was not visible where it came to rest beneath the ventilation duct.

Tank condition had not changed. Stains and marks on the primary vessel wall were caused by water which had leaked into the annulus.

Tank condition had not changed. A white deposit has seeped through and highlighted the crack since inspected on 03/20/97.

Tank condition had not changed.

Tank condition had not changed. Stains and deposits on the primary vessel wall appeared to be calciferous material deposited by water leaking into the annulus.

The probe in IP-117 was lifted up so that it could be observed, then lowered to the floor between the ventilation duct and the secondary vessel wall. The probe was not visible where it came to rest beneath the ventllation duct.

\section{Tank condition had not changed. \\ Tank condition had not changed. \\ Tank conditlon had not changed.}

Inspection revealed the white deposits observed on the primary vessel wall and annulus floor on $3 / 29 / 99$ were calciferous deposits formed by rainwater inleakage leaching the concrete tank top.

Tank condition had not changed. 


\begin{tabular}{|c|c|c|c|c|c|c|}
\hline \multirow{2}{*}{$\frac{\text { AREA }}{H}$} & \multirow{2}{*}{$\begin{array}{c}\text { TANK OR } \\
\text { ANCILLARY } \\
15\end{array}$} & \multicolumn{2}{|c|}{$\frac{\text { ACCESS OPENING }}{(A \text { OR l) }}$} & \multirow{2}{*}{$\frac{\text { DATE }}{03 / 29 / 99}$} & \multirow{2}{*}{$\frac{\text { METHOD }}{\text { WAP }}$} & \multirow{2}{*}{$\frac{\text { FILE I.D. \# }}{\text { P990547:01 }}$} \\
\hline & & 223 & (A) & & & \\
\hline H & 15 & 242 & (A) & $11 / 03 / 99$ & CCTV & 556 \\
\hline & & & - & & & \\
\hline $\mathbf{H}$ & 15 & East & (A) & 03/29/99 & WAP & P990547:02 \\
\hline $\mathrm{H}$ & 15 & North & (A) & 03/29/99 & WAP & P990547:03 \\
\hline $\mathbf{H}$ & 15 & South & (A) & $12 / 02 / 99$ & DP & P990702:01-17 \\
\hline$H$ & 15 & West & (A) & $03 / 29 / 99$ & WAP & P990547:04 \\
\hline H & 15 & 01 & (l) & $06 / 14 / 99$ & CCTV & 590 \\
\hline H & 16 & VB & & $08 / 23 / 99$ & CCTV & 554 \\
\hline H & 16 & 035 & (A) & $10 / 26 / 99$ & DP & P99 \\
\hline
\end{tabular}

Tank condition had not changed. Stains, marks, and deposits on the primary vessel wall and annulus floor were observed. Further investigation performed on $07 / 15 / 99$ revealed that calciferous deposits had increased since 03/20/97.

The magnetically mounted thermocouple was deployed at the setpoint.

Tank condition had not changed.

Tank condition had not changed. Stains and marks on the annulus floor were caused by water which had leaked into the annulus.

Tank condition had not changed. Deposits were observed on the annulus floor.

Tank condition had not changed.

CCTV was used to record steel taping and to observe for dusting and determine uniformity of sludge level. No dusting was observed. No free standing liquid was observed in the tank. Abandoned steel tapes were observed below riser 01 .

The conductivity probe was deployed at the setpoint.

Tank condition had not changed. Stains observed on the primary vessel wall, secondary vessel wall and the annulus floor have been altered by condensate formed on these steel surfaces. A plece of plastic sleeving was observed on top of the ventilation duct.

Tank condition had not changed. Stains and marks observed on the primary vessel wall were caused by water which had leaked into the annulus. The appearance of stains observed on the primary vessel wall, secondary vessel wall and the annulus floor have been altered by condensate formed on these steel surfaces.

Tank condition had not changed. Stains and marks observed on the primary vessel wall were caused by water which had leaked into the annulus. The appearance of stains observed on the primary vessel wall, secondary vessel wall and the annulus floor have been altered by condensate formed on these steel surfaces. 


\section{TANK OR ACCESS OPENING}

$\frac{\text { AREA }}{H} \frac{\text { ANCILLARY }}{16} \frac{(A \text { OR I) }}{262 \quad \text { (A) } \frac{\text { DATE }}{10 / 26 / 99}} \frac{\text { METHOD }}{\text { DP }} \frac{\text { FILE I.D. \# }}{\text { P990697:01-17 }}$

H

16

East

$11 / 04 / 99$

WAP

P990700:01

H

16

West

(A)

$11 / 04 / 99$

WAP

P990700:02

F

18

MLDB-10

$01 / 12 / 99$

CCTV

554

F

18

MLDB-12

18

Center

(I)

07/14/99

CCTV

593

F

18

Center

(I)

$11 / 18 / 99$

CCTV

637

F

19

Center

(I)

$11 / 11 / 99$

CCTV

636

H

21

MLDB-01

H

H

H

H

21

21

MLDB-01

21

VB

21

VB

NE
$05 / 09 / 99$

05/13/99

05/10/99

06/06/99

(l) $08 / 25 / 99$

cctV

\section{REMARKS}

Tank condition had not changed. Stains and marks observed on the primary vessel wall were caused by water which had leaked onto the annulus. The appearance of stains observed on the primary vessel wall, secondary vessel wall and the annulus floor have been altered by condensate formed on these steel surfaces.

Tank condition had not changed. Stains and marks on the primary vessel wall were caused by water which had leaked into the annulus. Water had leaked into the annulus and reconfigured the leaked waste in the annulus pan.

Tank conditlon had not changed. Water had leaked Into the annulus and reconfigured the leaked waste in the annulus pan.

Assisted in determining the position of the conductivity probe. The probe was not visible due to debris in the MLDB.

The conductivity probe was deployed at the setpoint.

Documented overall condition of tank interior. No anomalles were observed.

Tank steel wall and concrete dome condition was normal. However, stains and marks on the dome indicated water continued to leak into the tank via the risers.

Tank steel wall condition had not changed and the concrete dome was normal.

The conductivity probe was deployed at the setpoint.

The conductivity probe was deployed at the setpoint.

Verified the position of valves WTS-V-359 and $\mathbf{3 6 0}$ in the closed position.

Viewed leak check of valves WTS-V-359 and 360 . The valves were leak free.

Inspected overall conditlon of the tank wall and concrete dome. A few small surface voids were observed in the concrete dome. Water marks and stains were observed on the concrete dome. 
TANK OR ACCESS OPENING

\begin{tabular}{|c|c|c|c|c|c|c|}
\hline AREA & ANCILLARY & $\angle A O$ & & DATE & METHOD & FILE I.D. \# \\
\hline H & 21 & NE & (l) & $08 / 31 / 99$ & CCTV & 617 \\
\hline H & 21 & $N E$ & (l) & $12 / 01 / 99$ & CCTV & 629 \\
\hline H & 22 & MLDB-01 & & $09 / 14 / 99$ & CCTV & \\
\hline H & 22 & MLDB-02 & & $02 / 25 / 99$ & CCTV & 554 \\
\hline H & 22 & MLDB-02 & & $02 / 26 / 99$ & cctv & 554 \\
\hline H & 22 & MLDB-02 & & $03 / 04 / 99$ & cctV & 554 \\
\hline H & 22 & MLDB-02 & & 04/14/99 & cctv & 554 \\
\hline H & 22 & VB & & $02 / 18 / 99$ & HELIUM & HE-99-001 \\
\hline
\end{tabular}

22

VB

$02 / 22 / 99$

HELIUM HE-99-002

H

22

NE

(l)

$08 / 25 / 99$

CCTV

616

H

22 NW

(I)

$08 / 25 / 99$

CCTV

616

H

22 NW

(I)

(I)

08/30/99 CCTV

\section{REMARKS}

Inspected overall condition of the tank wall and concrete dome. A few small surface voids were observed in the concrete dome. Water marks and stains were observed on the concrete dome.

Tank steel wall and concrete dome condition were normal. Some calciferous deposits, which indicate that water has been leaking through the concrete dome for an extended period of time, were observed.

The conductivity probe was deployed at the setpoint.

The conductivity probe was deployed at the setpoint. However, mud was observed on the bottom of the MLDB.

The conductivity probe was deployed at the setpoint.

Inspection was made to determine the reason the probe was in the alarm mode. The probe was properiy positioned. However, the bottom of the MLDB was covered with a molst residue.

The conductivity probe was deployed at the setpoint.

Helium tracer test of the transfer line from the Tank 22 valve box to Tank 22 identitied a leak site location for excavation and repair.

Helium tracer test of the transfer llne from the Tank 22 valve box to Tank 22 validated the results of the test performed on 02/18/99.

Inspected overall condition of the tank wall and concrete dome. Water marks and stains were observed on the concrete dome.

Inspected overall condition of the tank wall and concrete dome. Water marks and stains were observed on the concrete dome.

Inspected overall condition of the tank wall and concrete dome. Water marks and stains were observed on the concrete dome. 


\section{TANK OR ACCESS OPENING}

\begin{abstract}
AREA ANCILLARY
\end{abstract}
H

22

NW$$
\text { DAT }
$$

$\frac{\text { METHOD }}{\text { CCTV }}$

FILE I.D. \#

629

H

23

SW

(l)

06/24/99

CCTV

593

H

23

SW

(I)

08/18/99

CCTV

608

H

24

North

H

24

North

24

NW

LDB-02

$11 / 04 / 9$

$02 / 22 / 99$

CCTV

554

F

LDB-03

02/23/99

CCTV

F

25

LDB-03

$05 / 24 / 99$

CCTV

554

F

25

LDB-03

06/02/99

CCTV

554

F

25

LDB-03

06/08/99

F

25

A-01

(A)

$01 / 29 / 99$

(A)

$01 / 29 / 99$
_CCTV _. 554

WAP P990494:01

WAP $\quad$ P990494:02

\section{REMARKS}

Tank condition was normal. Inspection revealed artifacts and calciferous deposits on the dome which indicate long-term water inleakage at three locations.

Tank steel wall condition was normal. Inspection of the concrete dome revealed a few small surface voids, water marks and stains, and an anomaly at the interface of the concrete dome and tank wall that require additional investigation.

A followup inspection to define the anomaly found on 6/24/99 revealed some crushing of the dome at the tank wall and dome interface. The crushed concrete spanned approximately fifteen feet at the base of the dome. Water intrusion was also observed on the concrete dome.

Documented conditlons of the riser and equipment configuration. Inspection revealed no evidence of waste leakage in the riser. The conductivity probe was not visible. An open drain path through the jet shielding plate to the tank was observed.

Determined the length of the conductlvity probe standpipe in the riser to establlsh distance to setpoint for the conductlvity probe installation.

Tank steel wall and concrete dome condition was normal.

The conductivity probe was deployed at setpoint.

Inspection revealed debris beneath the standipipe, which prevented the conductivity probe from being properly positioned.

The conductivity probe was not observed. Debrls and mud was observed on the floor beneath the standpipe.

Inspection was used to evaluate the effectiveness of flushing. The LDB drained freely and the conductivity probe was deployed at the setpoint.

Assisted with the positioning of a new .. conductivity probe at the setpoint.

Tank condition was normal.

Tank condition was normal. 
TANK OR ACCESS OPENING

\begin{tabular}{|c|c|c|c|c|c|c|}
\hline REA & ANCILLARY & \multicolumn{2}{|c|}{ (A OR I) } & DATE & METHOD & FILE I.D. \\
\hline $\mathbf{F}$ & 25 & A-02 & (A) & $03 / 16 / 99$ & CCTV & 556 \\
\hline $\mathbf{F}$ & 25 & $A-03$ & (A) & $01 / 29 / 99$ & WAP & P990494:03 \\
\hline $\mathbf{F}$ & 25 & A-03 & (A) & $03 / 16 / 99$ & cctV & 556 \\
\hline $\mathbf{F}$ & 25 & $A-04$ & (A) & $03 / 16 / 99$ & CCTV & 556 \\
\hline$F$ & 25 & $A-04$ & (A) & $06 / 29 / 99$ & WAP & P990633:01 \\
\hline
\end{tabular}

F

F

F

F

F

$F$

F

F

\section{5}

P-01

(A)

01/29/99

(A)

$01 / 29 / 99$

(A) $01 / 29 / 99$

(A) $\quad 01 / 29 / 99$

P-04

P-05

(A)

01/29/99

P-05

(A)

02/23/99

P-06

(A)

$01 / 29 / 99$

(A)

$01 / 29 / 99$

(A)

01/29/99

(A) $01 / 29 / 99$

P-09

25

P-10

(A)

01/29/99

(A) $01 / 29 / 99$

(A) $01 / 29 / 99$

P-12

P-13

(A)

$01 / 29 / 99$

(A) $01 / 29 / 99$
$25 \quad$ P-14

26
LDB-02
02/27/99
WAP

P990494:04

P990494:05

P990490:01-25

P990491:01-25

P990494:06

WAP

CCTV

NA

WAP

WAP

P990494:08

WAP

P990494:09

WAP P990494:10

WAP

DP

P990492:01-25

DP

P990493:01-25

WAP

P990494:12

WAP P990494:13

CCTV $\quad 554$

\section{REMARKS}

The conductivity probe was deployed at the setpoint.

Tank condition was normal.

The conductivity probe was deployed at the setpoint.

The conductivity probe was deployed at the setpoint.

Tank condition was normal. Stains and marks on the secondary vessel wall were caused by water which had leaked into the annulus.

Tank condition was normal.

Tank condition was normal.

Tank condition was normal.

Tank condition was normal.

Tank condition was normal. An unidentified item was observed on the floor.

Inspection revealed that the item observed on 01/29/99 WAP was a radiological tag.

Tank condition was normal.

Tank condition was normal.

Tank condition was normal.

Tank condition was normal. Stains and marks on top of the ventilation duct were caused by water which had leaked Into the annulus.

Tank condition was normal.

Tank condition was normal.

Tank condition was normal.

Tank condition was normal.

Tank condition was normal.

The conductivity probe was deployed at the setpoint. 
TANK OR ACCESS OPENING

\begin{tabular}{|c|c|c|c|c|c|c|c|}
\hline AREA & ANCILLARY & (AO & & DATE: & METHOD & FILE I.D. \# & REMARKS \\
\hline $\mathbf{F}$ & 26 & LDB-04 & & 03/05/99 & CCTV & 554 & $\begin{array}{l}\text { The conductivity probe was deployed at } \\
\text { the setpoint. }\end{array}$ \\
\hline $\mathbf{F}$ & 26 & LDB-05 & & $02 / 27 / 99$ & CCTV & 554 & $\begin{array}{l}\text { The conductivity probe was deployed at } \\
\text { the setpoint. }\end{array}$ \\
\hline $\mathbf{F}$ & 26 & LDB-07 & & 03/29/99 & CCTV & 554 & $\begin{array}{l}\text { The conductivity probe was deployed at } \\
\text { the setpoint. }\end{array}$ \\
\hline $\mathbf{F}$ & 26 & LDB-08 & & $02 / 27 / 99$ & CCTV & 554 & $\begin{array}{l}\text { The conductivity probe was deployed at } \\
\text { the setpoint. }\end{array}$ \\
\hline $\mathbf{F}$ & 26 & LDB-10 & & $05 / 26 / 99$ & CCTV & 554 & $\begin{array}{l}\text { The conductivity probe was deployed at } \\
\text { the setpoint. }\end{array}$ \\
\hline $\mathbf{F}$ & 26 & A-01 & (A) & $04 / 20 / 99$ & DP & P990650:01-24 & Tank condition was normal. \\
\hline $\mathbf{F}$ & 26 & A-02 & (A) & $04 / 20 / 99$ & DP & P990563:01-24 & Tank condition was normal. \\
\hline $\mathbf{F}$ & 26 & A-02 & (A) & $04 / 20 / 99$ & DP & P990563:21 & $\begin{array}{l}\text { The conductivity probe was deployed at } \\
\text { the setpoint. }\end{array}$ \\
\hline $\mathbf{F}$ & 26 & A-03 & (A) & $04 / 20 / 99$ & DP & P990564:01-25 & Tank condition was normal. \\
\hline $\mathbf{F}$ & 26 & A-03 & (A) & $04 / 20 / 99$ & DP & P990564:21 & $\begin{array}{l}\text { The conductivity probe was deployed at } \\
\text { the setpoint. }\end{array}$ \\
\hline $\mathbf{F}$ & 26 & A-04 & (A) & $04 / 20 / 99$ & DP & P990565:01-25 & Tank condition was normal. \\
\hline $\boldsymbol{F}$ & 26 & A-04 & (A) & $04 / 20 / 99$ & DP & P990565:21 & $\begin{array}{l}\text { The conductivity probe was deployed at } \\
\text { the setpoint. }\end{array}$ \\
\hline $\mathbf{F}$ & 26 & P-01 & (A) & 01/29/99 & WAP & P990495:01 & Tank condition was normal. \\
\hline F & 26 & P.02 & (A) & $01 / 29 / 99$ & WAP & P990495:02 & Tank condition was normal. \\
\hline $\mathbf{F}$ & 26 & P-03 & (A) & $01 / 29 / 99$ & WAP & P990495:03 & Tank condition was normal. \\
\hline$F$ & 26 & P.04 & (A) & $01 / 29 / 99$ & WAP & P990495:04 & Tank conditlon was normal. \\
\hline $\mathbf{F}$ & 26 & P-05 & (A) & $01 / 29 / 99$ & WAP & P990495:05 & Tank conditlon was normal. \\
\hline $\mathbf{F}$ & 26 & P-06 & (A) & $01 / 29 / 99$ & WAP & P990495:06 & Tank condition was normal. \\
\hline $\mathbf{F}$ & 26 & P-07 & (A) & $01 / 29 / 99$ & WAP & P990495:07 & Tank condition was normal. \\
\hline$F$ & 26 & P.08 & (A) & 01/29/99 & WAP & P990495:08 & Tank condition was normal. \\
\hline $\mathbf{F}$ & 26 & P-09 & (A) & $01 / 29 / 99$ & WAP & P990495:09 & Tank condition was normal. \\
\hline $\mathbf{F}$ & 26 & P-10 & (A) & $01 / 29 / 99$ & WAP & P990495:10 & Tank condition was normal. \\
\hline $\mathbf{F}$ & 26 & P-11 & (A) & $01 / 29 / 99$ & WAP & P990495:11 & Tank condition was normal. \\
\hline
\end{tabular}


TANK OR ACCESS OPENING AREA ANCILLARY

\begin{tabular}{|c|c|c|c|c|c|c|}
\hline REA & ANCILLARY & & & DATE & METHOD & FILE I.D. \# \\
\hline $\mathbf{F}$ & 26 & P-12 & (A) & $01 / 29 / 99$ & WAP & P990495:12 \\
\hline $\mathbf{F}$ & 26 & P-13 & (A) & $01 / 29 / 99$ & WAP & P990495:13 \\
\hline $\mathbf{F}$ & 26 & P-14 & (A) & $01 / 29 / 99$ & WAP & P990495:14 \\
\hline $\mathbf{F}$ & 26 & H & (I) & $02 / 27 / 99$ & CCTV & 562 \\
\hline
\end{tabular}$$
\text { F }
$$

27

LDB-01

F

27

LDB-04

F

27

LDB-05

F

$\mathbf{F}$

F

F

$\mathbf{F}$

$\mathbf{F}$

$\mathbf{F}$

$\mathbf{F}$

F

F

F

F

F

F

F
27

27

27

27

27

27

27

27

27

27

27

27

27

27

27

27

\section{A-01}

A-02

A-02

A-03

A-03

A-04

A-04

P-01

P-02

P-03

P-04

P-05

P-06

P-07

P-08

P-09
02/22/99

01/22/99

02/23/99

(A)

(A) $01 / 29 / 99$

(A) $08 / 16 / 99$

(A)

06/29/99

(A) $08 / 16 / 99$

(A) $01 / 29 / 99$

(A) $08 / 16 / 99$

(A) $01 / 29 / 99$

(A) $01 / 29 / 99$

(A) $01 / 29 / 99$

(A) $01 / 29 / 99$

(A) $01 / 29 / 99$

(A) $01 / 29 / 99$

(A) $01 / 29 / 99$

(A) $01 / 29 / 99$

(A) $01 / 29 / 99$
CCTV 554

CCTV 554

CCTV 554

WAP

P990485:01

WAP

P990485:02

CCTV 556

WAP

CCTV

556

WAP

P990485:03

CCTV $\quad 556$

WAP

P990485:04

WAP

P990485:05

DP

DP

WAP

WAP

P990485:07

WAP

P990485:08

WAP

P990485:09

WAP

P990485:10
Tank condition was normal.

Tank condition was normal.

Tank condition was normal.

Inspection revealed some foam or froth and a small amount of organic material floating on the liquid.

The conductivity probe was deployed at the setpoint.

The conductivity probe was deployed at the setpoint. There was a considerable amount of residue on the floor of the LDB.

The conductivity probe was deployed at the setpoint.

Tank condition was normal.

Tank condition was normal.

The conductivity probe was deployed at the setpoint.

Tank condition was normal.

The conductivity probe was deployed at the setpoint.

Tank condition was normal.

The conductivity probe was deployed at the setpoint.

Tank condition was normal.

Tank condition was normal.

Tank condition was normal.

Tank condition was normal.

Tank condition was normal.

Tank condition was normal.

Tank condition was normal.

Tank condition was normal.

Tank condition was normal. 
TANK OR ACCESS OPENING

$\frac{\text { AREA }}{\mathrm{F}} \frac{\text { ANCILLARY }}{27} \frac{(A \text { OR I) }}{\mathrm{P}-10 \quad \text { (A) }} \frac{\text { DATE }}{01 / 29 / 99} \frac{\text { METHOD }}{\text { DP }} \frac{\text { FILE I.D.\# }}{\text { P990488:01-25 }}$

$\mathbf{F}$

$F$

F

F

F

$\mathbf{F}$

$F$

$\mathbf{F}$

$\mathbf{F}$

$\mathbf{F}$

F

$\mathbf{F}$

$\mathbf{F}$

$\mathbf{F}$

$F$

$\mathbf{F}$

$\mathbf{F}$
27

P-11

(A) $01 / 29 / 99$

(A) $01 / 29 / 99$

(A)

$01 / 29 / 99$

(A)

01/29/99

06/08/99

NA

06/10/99

CCTV

554

$04 / 21 / 99$

06/08/99

CCTV

NA

$06 / 10 / 99$

01/20/99

(A)

04/20/99

(A) $04 / 20 / 99$

A-02

A-02

28

(A) $08 / 16 / 99$

(A) $04 / 20 / 99$

A-03

A-03

(A) $08 / 16 / 99$

CCTV

556

A-04

(A) $04 / 20 / 99$

DP

P990568:01-25

A-04

(A) $04 / 20 / 99$

DP

P990568:21
28

28

28
P-01

(A)

$01 / 29 / 99$

WAP

P990496:01

(A) $01 / 29 / 99$
P-02
REMARKS

Tank condition was normal. Stains and marks on the secondary vessel wall were caused by water which had leaked into the annulus.

Tank condition was normal.

Tank condition was normal.

Tank condition was normal.

Tank condition was normal.

Inspection was used to determine that the LDB was successfully flushed.

The conductivity probe was deployed at the setpoint.

The conductivity probe was deployed at the setpoint.

Inspection was used to determine that the LDB was successfully flushed.

The conductivity probe was deployed at the setpoint.

Verified that the conductivity probe was positioned on the bottom of the VB.

Verified that the conductivity probe was positioned on the bottom of the VB.

Tank condition was normal.

Tank condition was normal.

The conductivity probe was deployed at the setpoint.

Tank condition was normal.

The conductivity probe was deployed at the setpoint.

Tank condition was normal.

The conductivity probe was deployed at the setpoint.

Tank condition was normal.

Tank condition was normal. 
TANK OR ACCESS OPENING

\begin{tabular}{|c|c|c|c|c|c|c|c|}
\hline AREA & ANCILLARY & (AO & 1) & DATE & METHOD & FILE I.D.\# & REMARKS \\
\hline$F$ & 28 & P-03 & (A) & $01 / 29 / 99$ & WAP & P990496:03 & Tank condition was normal. \\
\hline $\mathrm{F}$ & 28 & P.04 & (A) & $01 / 29 / 99$ & WAP & P990496:04 & Tank condition was normal. \\
\hline$F$ & 28 & P.05 & (A) & $01 / 29 / 99$ & WAP & P990496:05 & Tank condition was normal. \\
\hline $\mathbf{F}$ & 28 & P.06 & (A) & $01 / 29 / 99$ & WAP & P990496:06 & Tank condition was normal. \\
\hline $\mathbf{F}$ & 28 & P.07 & (A) & $01 / 29 / 99$ & WAP & P990496:07 & Tank condition was normal. \\
\hline $\mathbf{F}$ & 28 & P.08 & (A) & $01 / 29 / 99$ & WAP & P990496:08 & Tank condition was normal. \\
\hline $\mathbf{F}$ & 28 & P-09 & (A) & $01 / 29 / 99$ & WAP & P990496:09 & Tank condition was normal. \\
\hline$F$ & 28 & P-10 & (A) & $01 / 29 / 99$ & WAP & P990496:10 & Tank condition was normal. \\
\hline $\mathbf{F}$ & 28 & P-11 & (A) & $01 / 29 / 99$ & WAP & P990496:11 & Tank condition was normal. \\
\hline$F$ & 28 & P-12 & (A) & $01 / 29 / 99$ & WAP & P990496:12 & Tank condition was normal. \\
\hline$F$ & 28 & P-13 & (A) & 01/29/99 & WAP & P990496:13 & Tank condition was normal. \\
\hline$F$ & 28 & P-14 & (A) & $01 / 29 / 99$ & WAP & P990496:14 & Tank condition was normal. \\
\hline H & 29 & LE-10229 & & $12 / 15 / 99$ & CCTV & 554 & $\begin{array}{l}\text { The conductivlty probe was deployed at } \\
\text { the setpoint. }\end{array}$ \\
\hline H & 29 & LE-10230 & & $12 / 15 / 99$ & CCTV & 554 & $\begin{array}{l}\text { The conductivity probe was deployed at } \\
\text { the setpoint. }\end{array}$ \\
\hline H & 29 & LPS & & $09 / 17 / 99$ & ccTV & 554 & $\begin{array}{l}\text { Determined the length of the leak probe } \\
\text { sleeve on the tank side-lift steam for } \\
\text { proper setpoint of the conductivity probe. }\end{array}$ \\
\hline H & 29 & A-01 & (A) & 04/19/99 & CсTV & 556 & $\begin{array}{l}\text { The conductivity probe was deployed at } \\
\text { the setpoint. }\end{array}$ \\
\hline H & 29 & A-01 & (A) & 06/03/99 & DP & P990617:01-25 & $\begin{array}{l}\text { Tank condition was normal. Stains on the } \\
\text { annulus floor were caused by water which } \\
\text { had leaked into the annulus where a } \\
\text { supernate inlet transfer line penetrates the } \\
\text { annulus. }\end{array}$ \\
\hline H & 29 & A-02 & (A) & 04/19/99 & cctV & 556 & $\begin{array}{l}\text { The conductivity probe was deployed at } \\
\text { the setpoint. }\end{array}$ \\
\hline$H$ & 29 & A-02 & (A) & 08/30/99 & DP & P990663:01-25 & Tank condition was normal. \\
\hline H & 29 & $A-03$ & (A) & 04/19/99 & CCTV & 556 & $\begin{array}{l}\text { The conductivity probe was deployed at } \\
\text { the setpoint. }\end{array}$ \\
\hline H & 29 & $A-03$ & (A) & $06 / 03 / 99$ & DP & P990618:01-25 & $\begin{array}{l}\text { Tank condition was normal. Stalns and } \\
\text { marks on the annulus floor were caused by } \\
\text { water which had leaked Into the annulus. }\end{array}$ \\
\hline
\end{tabular}


TANK OR ACCESS OPENING

\begin{tabular}{|c|c|c|c|c|c|c|c|}
\hline AREA & ANCILLARY & & & DATE & METHOD & FILE I.D. \# & REMARKS \\
\hline H & 29 & A-04 & (A) & $06 / 03 / 99$ & DP & P990619:01-25 & Tank condition was normal. \\
\hline H & 29 & P.01 & (A) & $05 / 11 / 99$ & WAP & P990573:01 & Tank condition was normal. \\
\hline H & 29 & P.03 & (A) & $05 / 11 / 99$ & WAP & P990573:03 & Tank condition was normal. \\
\hline H & 29 & P.04 & (A) & $05 / 11 / 99$ & WAP & P990573:04 & Tank condition was normal. \\
\hline H & 29 & P-07 & (A) & $05 / 11 / 99$ & WAP & P990573:07 & Tank condition was normal. \\
\hline H & 29 & P-08 & (A) & $05 / 11 / 99$ & WAP & P990573:08 & Tank condition was normal. \\
\hline H & 29 & P.09 & (A) & $05 / 11 / 99$ & WAP & P990573:09 & Tank condition was normal. \\
\hline H & 29 & $P-10$ & (A) & $05 / 11 / 99$ & WAP & P990573:10 & Tank condition was normal. \\
\hline H & 29 & P-11 & (A) & $05 / 11 / 99$ & WAP & P990573:11 & Tank condition was normal. \\
\hline H & 29 & C-02 & (l) & 01/28/99 & CCTV & 564 & $\begin{array}{l}\text { Facilitated the removal of the loop line } \\
\text { spool plece installed in the riser and the } \\
\text { installation of a backflush valve. Verifled } \\
\text { that the BFV and nozzle were properly } \\
\text { aligned. }\end{array}$ \\
\hline H & 30 & LPS & & $09 / 18 / 99$ & CCTV & 554 & $\begin{array}{l}\text { Determined the length of the leak probe } \\
\text { sleeve on the tank side-North for proper } \\
\text { setpoint of the conductivity probe. }\end{array}$ \\
\hline H & 30 & $A-01$ & (A) & $04 / 19 / 99$ & CCTV & 556 & $\begin{array}{l}\text { The conductivity probe was deployed at } \\
\text { the setpoint. }\end{array}$ \\
\hline H & 30 & A-01 & (A) & $06 / 02 / 99$ & DP & P990620:01-25 & Tank condition was normal. \\
\hline H & 30 & $A-02$ & (A) & $04 / 15 / 99$ & CCTV & 556 & $\begin{array}{l}\text { The conductivity probe was deployed at } \\
\text { the setpoint. }\end{array}$ \\
\hline H & 30 & A-02 & (A) & $06 / 01 / 99$ & DP & P990621:01-26 & Tank condition was normal. \\
\hline
\end{tabular}


TANK OR ACCESS OPENING

AREA ANCILLARY

$$
\text { H }
$$

30 (A OR I)

A-03

A-03

(A) $06 / 01 / 99$

(A) $04 / 19 / 99$

A-04

A-04

(A) $06 / 02 / 99$

P-01

(A) $05 / 11 / 99$

(A) $05 / 11 / 99$

(A) $05 / 11 / 99$

(A) $05 / 11 / 99$

P-04

P-05

(A) $05 / 11 / 99$

P-06

(A) $03 / 25 / 99$

H

H

H

H

H

H

H

H

H

H

H

H

H
P-07

31

A-01

30

30

P-09

P-10

P-11

P-12

P-13

P-14

C.02

(A) $03 / 25 / 99$

(A) $03 / 25 / 99$

(A) $03 / 25 / 99$

(A) $03 / 25 / 99$

(A) $03 / 25 / 99$

(A) $03 / 25 / 99$

(A) $03 / 25 / 99$

(A) $03 / 25 / 99$

(l) $04 / 29 / 99$

CCTV

NA

(A) $04 / 15 / 99 \quad$ CCTV 556

A-01

A-02

31

31

A-02

(A) $06 / 01 / 99$

(A) $04 / 19 / 99 \quad$ CCTV 556

(A) $06 / 01 / 99$

DP

P990614:01-25

\section{REMARKS}

The conductivity probe was deployed at the setpoint.

Tank condition was normal.

The magnetically mounted thermocouple was deployed at the setpoint.

Tank condition was normal.

Tank condition was normal.

Tank condition was normal.

Tank condition was normal.

Tank condition was normal.

Tank condition was normal.

Tank condition was normal.

Tank condition was normal.

Tank condition was normal.

Tank condition was normal.

Tank condition was normal.

Tank condition was normal.

Tank condition was normal.

Tank condition was normal. A masselln cloth was observed on the annulus floor.

Tank condition was normal.

Inspection of the thermowell for the BFV revealed that there were no obstruction that would prevent the thermocouple from being inserted.

The conductivity probe was deployed at the setpoint.

Tank condition was normal.

The conductivity probe was deployed at the setpoint.

Tank condition was normal. 
TANK OR ACCESS OPENING

\begin{tabular}{|c|c|c|c|c|c|c|}
\hline AREA & ANCILLARY & & & DATE & METHOD & FILE I.D. \# \\
\hline$H$ & 31 & A-03 & (A) & $04 / 19 / 99$ & CCTV & 556 \\
\hline H & 31 & $A \cdot 03$ & (A) & $06 / 02 / 99$ & DP & P990615:01 \\
\hline H & 31 & $A-04$ & (A) & $04 / 15 / 99$ & CCTV & 556 \\
\hline H & 31 & A-04 & (A) & $06 / 02 / 99$ & DP & P990616:01 \\
\hline
\end{tabular}

31

A-04

(A) $08 / 10 / 99$

(A) $05 / 11 / 99$

(A) $05 / 11 / 99$

(A) $03 / 25 / 99$

(A) $03 / 25 / 99$

(A) $03 / 25 / 99$

(A) $03 / 25 / 99$

(A) $03 / 25 / 99$

(A) $03 / 25 / 99$

(A) $\quad 03 / 25 / 99$

P-09

P-10

(A) $\quad 03 / 25 / 99$

(A) $03 / 25 / 99$

(A) $03 / 25 / 99$

P-12

P-13

(A) $03 / 25 / 99$

(A) $06 / 03 / 99$

09/18/99

LDB-101

H

32

H

32

LDB-101
11/22/99
CCTV 556

WAP P990581:01

WAP

P990581:02

WAP

P990552:01

WAP

P990552:02

WAP

WAP

WAP

WAP

P990552:06

WAP

P990552:07

P990552:08

WAP

WAP

P990552:09

WAP

P990552:10

WAP

P990552:11

WAP

P990628:01

CCTV 554

CCTV
REMARKS

The conductivity probe was deployed at the setpoint.

Tank condition was normal.

The magnetically mounted thermocouple was deployed at the setpoint.

Tank condition was normal. Stains and marks on the secondary vessel wall, ventilation duct, and annulus floor were caused by water which had leaked into the annulus. Nylon rope and an abandoned probe wire were observed on the annulus floor beneath the riser.

A new magnetically mounted thermocouple was deployed at the setpolnt.

Tank condition was normal.

Tank condition was normal.

Tank condition was normal.

Tank condition was normal.

Tank condition was normal.

Tank condition was normal.

Tank condition was normal.

Tank condition was normal.

Tank condition was normal.

Tank condition was normal.

Tank condition was normal.

Tank condition was normal.

Tank condition was normal.

Tank condition was normal.

The conductlvity probe was deployed at the setpoint.

The conductivity probe was deployed at the setpoint. 


\section{TANK OR ACCESS OPENING}

$\begin{array}{cccccc}\frac{\text { AREA }}{H} & \frac{\text { ANCILLARY }}{32} \frac{\frac{\text { (A OR I) }}{\text { LDB-102 }}}{\frac{09 / 21 / 99}{\text { CCTV }}} \frac{\text { DATE }}{554} & \frac{\text { METHOD }}{\text { FILE I.D. \# }} \\ \text { H } & 32 & \text { LDB-102 } & 09 / 21 / 99 & \text { CCTV } & 554\end{array}$

H

LDB-102

$09 / 21 / 99$

CCTV

554

H

32

LDB-102

09/22/99

CCTV

554

H

LDB-102

32

LDB-102

32

LDB-103

32

LE-10008-A

$12 / 08 / 99$

CCTV

NA

H

32

LE-10008-B

12/08/99

CCTV

NA

H

LPS-10813

09/17/99

CCTV

554

H

32

LPS-6063

32

A-01

(A)

04/19/99

CCTV

556

H

32

A-01

(A)

06/02/99

DP

P990624:01-25

\section{REMARKS}

The conductivity probe was deployed at the setpoint.

During measurement and reinstallation of the conductivity probe, inspection of the standpipe revealed an obstruction at approximately 102 inches from the top of the standpipe. The obstruction appears to be an aluminum rod.

The conductivity probe was deployed at the setpoint on the northeast side of tank.

Assisted with removal an obstruction from the standpipe. A piece of galvanized metal rod approximately $21 / 2$ feet long was removed.

The conductivity probe was deployed at the setpoint.

The conductivity probe was deployed at the setpoint.

The conductivity probe was positioned on the LDB floor.

Determined the length of the conductivity probe standpipe in the riser to establish distance to setpoint for the conductivity probe installation.

Determined the length of the conductivity probe standpipe in the riser to establish distance to setpoint for the conductivity probe installation.

Determined the length of the leak probe sleeve on the tank side-evaporator pot transfer line for proper installation of the conductivity probe.

Determined the length of the leak probe sleeve on the tank side-evaporator sump transfer line for proper installation of the conductivity probe.

The conductivity probe was deployed at the setpoint.

Tank condition was normal. Stalns and marks on the annulus floor were caused by water which had leaked into the annulus.

The conductivity probe was deployed at the setpoint. 


\section{TANK OR ACCESS OPENING}

AREA ANCILLARY

A-D

\section{(A OR I)}

$32 \quad$ A-02

(A)

$\frac{\text { DATE }}{06 / 02 / 99} \frac{\text { METHOD }}{\text { DP }}$

FILE I.D. \#

P990625:01-25

H

H

H

H

H

H

H

H

H

H

H

H

H

H

H

32

P-10

(A) $05 / 11 / 99$

WAP

P990578:10

H

$32 \quad \mathrm{P}-11$

(A) $04 / 19 / 99 \quad$ CCTV 556

(A)

(A) $04 / 19 / 99$

(A) $\quad 04 / 20 / 99$

(A) $06 / 02 / 99$

(A)

$05 / 11 / 99$

WAP

P990578:01

(A) $05 / 11 / 99$

(A) $05 / 11 / 99$

(A) $\quad 05 / 11 / 99$

(A) $05 / 11 / 99$

(A) $05 / 11 / 99$

(A)

$05 / 11 / 99$

(A)

$05 / 11 / 99$

(A) $05 / 11 / 99$

WAP

P990578:09

32 P-12

(A) $05 / 11 / 99$

WAP

P990578:11

(A) $08 / 31 / 99$

\section{REMARKS}

Tank condition was normal. Stains and marks on the secondary vessel wall have increased since inspected on 04/20/95.

The conductivity probe was deployed at the setpoint.

Tank condition was normal.

The magnetically mounted thermocouple was not positioned correctly.

The magnetically mounted thermocouple was deployed at the setpoint.

Tank condition was normal. An abandoned probe wire, two masselin cloths, and a swipe were observed on the annulus floor.

Tank condition was normal. Calciferous deposits on the secondary vessel wall have increased since inspected on $5 / 18 / 98$.

Tank condition was normal. Calciferous deposits on the secondary vessel wall have increased since inspected on 5/18/98.

Tank condition was normal.

Tank condition was normal.

Tank condition was normal.

Tank condition was normal. Calciferous deposits on the secondary vessel wall have increased since inspected on 6/24/97.

Tank condition was normal.

Tank condition was normal.

Tank condition was normal. Calciferous deposits on the secondary vessel wall and annulus floor have increased since inspected on $6 / 24 / 97$.

Tank condition was normal. Calciferous deposits on the secondary vessel wall and annulus floor have increased since inspected on 6/24/97.

Tank condition was normal.

Tank condition was normal. 


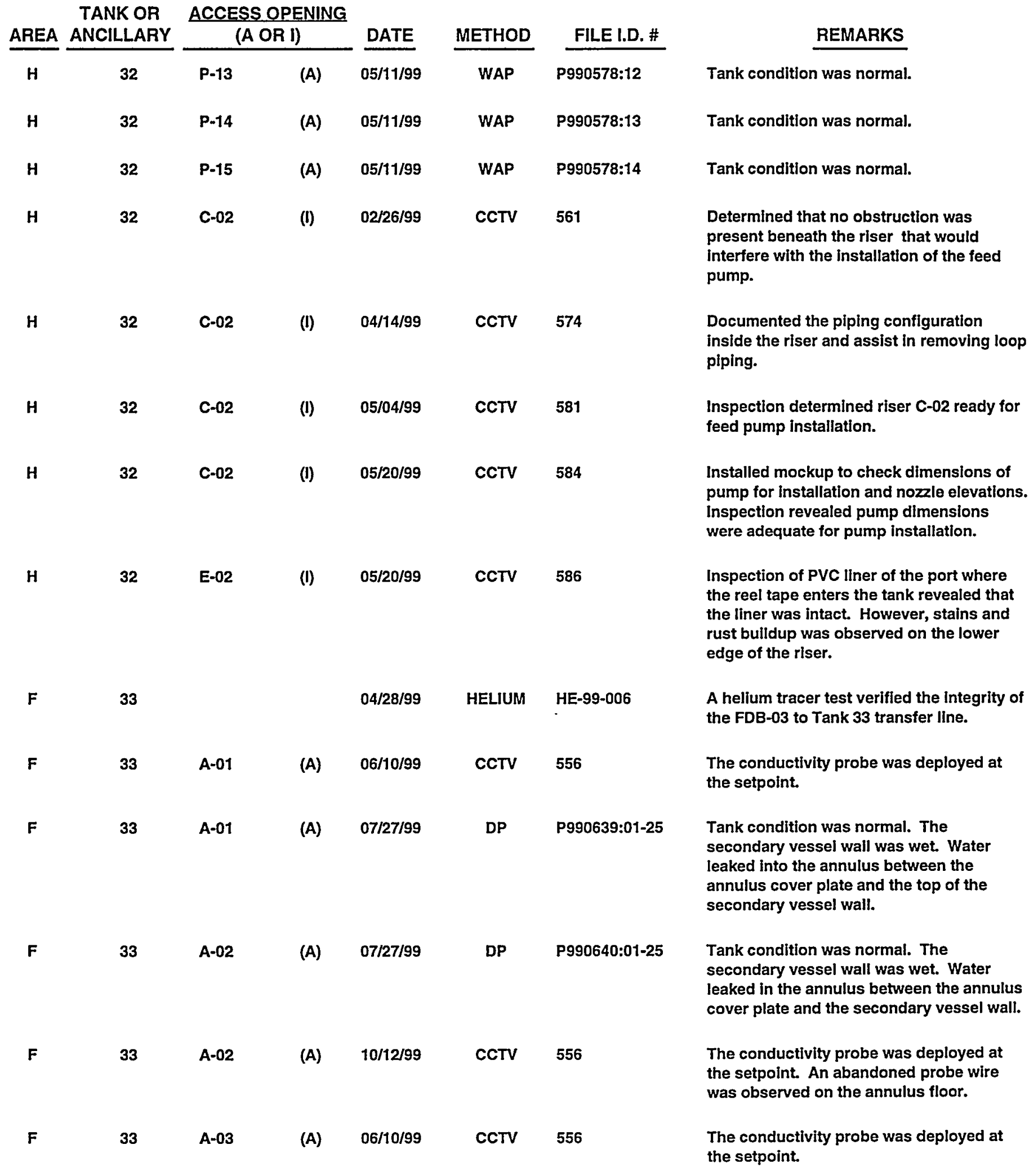


TANK OR ACCESS OPENING

\begin{tabular}{|c|c|c|c|c|c|c|}
\hline AREA & ANCILLARY & & & DATE & METHOD & FILE I.D. \# \\
\hline $\mathbf{F}$ & 33 & A-03 & (A) & $07 / 27 / 99$ & DP & P990641:01 \\
\hline $\mathbf{F}$ & 33 & A-04 & (A) & $06 / 10 / 99$ & CCTV & 556 \\
\hline$F$ & 33 & A.04 & (A) & $07 / 27 / 99$ & DP & P990642:01 \\
\hline
\end{tabular}

F

F

F

$F$

$F$

$F$

$\mathbf{F}$

$F$

$F$

F
33

P-01

(A)

$05 / 05 / 99$

(A)

05/05/99

(A)

05/05/99

(A)

05/05/99

(A) $05 / 05 / 99$

(A) $05 / 05 / 99$

(A) $05 / 05 / 99$

(A)

05/05/99

(A)

05/06/99

(A)

05/06/99

(A) $05 / 05 / 99$

(A) $05 / 05 / 99$

P-12

P-13

(A)

05/05/99

(A) $05 / 05 / 99$

(A)

05/05/99

(A)

05/05/99

(I)

$04 / 14 / 99$
WAP

P990570:01

WAP

P990570:02

WAP

P990570:03

WAP

P990570:04

WAP

P990570:05

WAP

P990570:06

WAP

P990570:07

WAP

P990570:08

WAP

P9g0572:01

WAP

P990572:02

WAP

P990570:09

WAP

P990570:10

WAP

P990570:11

WAP

P990570:12

WAP

P990570:13

WAP

P990570:14

CCTV

\section{REMARKS}

Tank condition was normal. The secondary vessel wall was wet. Water leaked in the annulus between the annulus cover plate and the top of the secondary vessel wall.

The magnetically mounted thermocouple was deployed at the setpoint.

Tank condition was normal. The secondary vessel wall was wet. Water leaked in the annulus between the annulus cover plate and the top of the secondary vessel wall.

Tank condition was normal.

Tank condition was normal.

Tank condition was normal.

Tank condition was normal.

Tank condition was normal.

Tank condition was normal.

Tank condition was normal.

Tank condition was normal.

Tank condition was normal.

Tank condition was normal.

Tank condition was normal.

Tank condition was normal.

Tank condition was normal.

Tank condition was normal.

Tank condition was normal.

Tank condition was normal.

Documented surface conditions. Inspection revealed a turbid liquid with small flotsam that could possibly be organic material. Tank overview appears normal. 
TANK OR ACCESS OPENING

\begin{tabular}{|c|c|c|c|c|c|c|}
\hline AREA & ANCILLARY & \multicolumn{2}{|c|}{ (A OR I) } & DATE & METHOD & FILE I.D. \# \\
\hline $\mathbf{F}$ & 34 & & & $04 / 28 / 99$ & HELIUM & HE-99-007 \\
\hline $\mathbf{F}$ & 34 & A-01 & (A) & $06 / 10 / 99$ & CCTV & 556 \\
\hline $\mathbf{F}$ & 34 & $A-01$ & (A) & 07/27/99 & DP & P990643:01-25 \\
\hline $\mathbf{F}$ & 34 & A-02 & (A) & $06 / 10 / 99$ & CCTV & 556 \\
\hline $\mathbf{F}$ & 34 & $A-02$ & (A) & 07/27/99 & DP & P990645:01-25 \\
\hline
\end{tabular}

$\boldsymbol{F}$

$\boldsymbol{F}$

F

F

F

F

F

$\mathbf{F}$

34

34

34

34

A-04

(A) $\quad 07 / 27 / 99$

(A)

05/05/99

(A)

$05 / 05 / 99$

(A)

$05 / 05 / 99$

(A)

05/05/99

(A)

05/05/99

P-05

34

P-06

(A)

05/05/99

WAP

P990571:06

34

P-07

34
(A) $05 / 05 / 99$
CCTV 556

DP

P990648:01-25

CCTV 556

DP P990649:01-25

WAP P990571:01

WAP $\quad$ P990571:02

WAP

P990571:03

P990571:04

P990571:05

\section{REMARKS}

A hellum tracer test verifled the integrity of the FDB-03 to Tank 34 transfer line.

The conductivity probe was deployed at the setpoint.

Tank condition was normal. Stains and marks on the primary and secondary vessel walls and the ventilation duct were caused by water inleakage.

The conductivity probe was deployed at the setpoint.

Tank condition was normal. Stalns and marks on the secondary vessel wall were caused by water which had leaked in between the annulus cover plate and the secondary vessel wall. A plastic bag was observed on the annulus floor.

The conductivity probe was deployed at the setpoint.

Tank condition was normal. Stains and marks on the secondary vessel wall were caused by water which had leaked in between the annulus cover plate and the secondary vessel wall.

The magnetically mounted thermocouple was deployed at the setpoint.

Tank condition was normal. Stains and marks on the primary vessel wall were caused by water which had leaked into the annulus.

Tank condition was normal.

Tank condition was normal.

Tank condition was normal.

Tank condition was normal.

Tank condition was normal.

Tank condition was normal. Stains and marks on the primary vessel wall were caused by water which had leaked into the annulus.

Tank condition was normal.

Tank condition was normal. 
TANK OR ACCESS OPENING

$\frac{\text { AREA }}{F} \frac{\text { ANCILLARY }}{34} \frac{(\text { A OR I) }}{\text { P-09 }} \frac{\text { DATE }}{\text { (A) }} \frac{\text { METHOD/99 }}{\text { WAP }} \frac{\text { FILE I.D.\# }}{\text { P990571:09 }}$

$\mathbf{F}$

$34 \quad \mathbf{P}-10$

$05 / 06 / 99$

WAP

P990571:10

$F$

$F$

F

$\boldsymbol{F}$

$\mathbf{F}$

H

H

$H$

H

H

H

H

H

35

H

H

H

H

H

H
P.01

P-11

(A)

05/06/99

(A)

05/06/99

(A) $05 / 06 / 99$

(A) $05 / 06 / 99$

(A) $05 / 06 / 99$

(A). 05/06/99

(A)

$02 / 03 / 99$

(A)

02/03/99

(A) $\quad 02 / 04 / 99$

(A) $02 / 03 / 99$

(A)

02/04/99

(A)

02/03/99

(A)

$02 / 04 / 99$

(A)

02/08/99

(A) $02 / 08 / 99$

(A)

02/08/99

(A)

02/08/99

(A)

02/03/99

(A) $02 / 03 / 99$

(A)

02/03/99
WAP P990571:11

WAP

P990571:12

WAP P990571:13

WAP $\quad$ P990571:14

WAP $\quad$ P990571:15

WAP P990571:16

WAP

WAP

CCTV

WAP

CCTV $\quad 556$

WAP

P990509:04

CCTV $\quad 556$

DP

P990497:01-25

DP

P990498:01-25

DP

P990499:01-25

DP

P990500:01-25

WAP

P990509:05

WAP

P990509:06
WAP P990509:07
REMARKS

Tank condition was normal. Stains and marks on the primary vessel wall were caused by water which had leaked Into the annulus.

Tank condition was normal. Stains and marks on the primary vessel wall were caused by water which had leaked Into the annulus.

Tank condition was normal.

Tank condition was normal.

Tank condition was normal.

Tank condition was normal.

Tank condition was normal.

Tank condition was normal.

Tank condition was normal.

Tank condition was normal.

The conductivity probe was deployed at the setpoint.

Tank condition was normal.

The conductivity probe was deployed at the setpoint.

Tank condition was normal.

The conductivity probe was deployed at the setpoint.

Tank condition was normal. A plece of paper approximately $10 \times 18$ inches was observed on the annulus floor.

Tank condition was normal.

Tank condition was normal.

Tank condition was normal.

Tank condition was normal.

Tank condition was normal.

Tank condition was normal. 
TANK OR ACCESS OPENING

\begin{tabular}{|c|c|c|c|c|c|c|c|}
\hline AREA & ANCILLARY & & & DATE & METHOD & FILE I.D.\# & REMARKS \\
\hline H & 35 & P-08 & (A) & $02 / 03 / 99$ & WAP & P990509:08 & Tank condition was normal. \\
\hline H & 35 & P-09 & (A) & $02 / 03 / 99$ & WAP & P990509:09 & Tank condition was normal. \\
\hline H & 35 & P-10 & (A) & $02 / 03 / 99$ & WAP & P990509:10 & Tank condition was normal. \\
\hline H & 35 & P-11 & (A) & $02 / 03 / 99$ & WAP & P990509:11 & Tank condition was normal. \\
\hline H & 35 & P-12 & (A) & 02/03/99 & WAP & P990509:12 & Tank condition was normal. \\
\hline H & 35 & P-13 & (A) & 02/03/99 & WAP & P990509:13 & Tank condition was normal. \\
\hline H & 35 & P-14 & (A) & 02/03/99 & WAP & P990509:14 & Tank condition was normal. \\
\hline H & 35 & B-04 & (I) & 07/20/99 & CCTV & 600 & $\begin{array}{l}\text { Inspection revealed that the } T T J \text { was in the } \\
\text { supernate. }\end{array}$ \\
\hline H & 35 & B-04 & (l) & 08/26/99 & CCTV & 600 & $\begin{array}{l}\text { Inspection revealed that the suction leg of } \\
\text { the } \Pi J \text { was at the supernate surface. }\end{array}$ \\
\hline H & 35 & C.01 & (l) & 10/27/99 & cctv & 559 & $\begin{array}{l}\text { Inspection revealed that the downcomer } \\
\text { was properly positioned. }\end{array}$ \\
\hline H & 36 & $A-01$ & (A) & 02/03/99 & WAP & P990510:01 & Tank condition was normal. \\
\hline H & 36 & A-02 & (A) & 02/03/99 & WAP & P990510:02 & Tank condition was normal. \\
\hline$H$ & 36 & A-02 & (A) & $02 / 04 / 99$ & CCTV & 556 & $\begin{array}{l}\text { The conductivity probe was deployed at } \\
\text { the setpoint. }\end{array}$ \\
\hline H & 36 & $A-03$ & (A) & 02/03/99 & WAP & P990510:03 & Tank condition was normal. \\
\hline H & 36 & A-03 & (A) & $02 / 04 / 99$ & cctV & 556 & $\begin{array}{l}\text { The conductivity probe was deployed at } \\
\text { the setpoint. }\end{array}$ \\
\hline H & 36 & $A-04$ & (A) & 02/03/99 & WAP & P990510:04 & Tank condition was normal. \\
\hline H & 36 & A-04 & (A) & $02 / 04 / 99$ & CCTV & 556 & $\begin{array}{l}\text { The conductivity probe was deployed at } \\
\text { the setpoint. }\end{array}$ \\
\hline H & 36 & P-01 & (A) & 02/08/99 & DP & P990504:01-25 & Tank condition was normal. \\
\hline H & 36 & P-02 & (A) & 02/08/99 & DP & P990505:01-25 & Tank condition was normal. \\
\hline H & 36 & P-03 & (A) & 02/08/99 & DP & P990506:01-25 & $\begin{array}{l}\text { Tank condition was normal. A cylindrical } \\
\text { object approximately } 2 \text { to } 3 \text { inches in } \\
\text { diameter was observed on the annulus } \\
\text { floor. }\end{array}$ \\
\hline H & 36 & P-04 & (A) & $02 / 08 / 99$ & DP & P990507:01-25 & Tank condition was normal. \\
\hline H & 36 & P-05 & (A) & 02/03/99 & WAP & P990510:05 & Tank condition was normal. \\
\hline H & 36 & P-06 & (A) & $02 / 03 / 99$ & WAP & P990510:06 & Tank condition was normal. \\
\hline
\end{tabular}


TANK OR ACCESS OPENING$$
\text { H }
$$

$$
\text { H }
$$

$$
\text { H }
$$

$$
\text { H }
$$

H

H

H

H

H

H

H

H

H

H

H

H

H

H

H

H

H

H

H

H AREA ANCILLARY$$
36
$$$$
\text { - }
$$

H

$$
36
$$

(A) DATE

(A) $02 / 03 / 99$

(A) $02 / 03 / 99$

(A) $02 / 03 / 99$

(A) $02 / 03 / 99$

(A) $02 / 03 / 99$

P-12

P-13

(A) $\quad 02 / 03 / 99$

(A) $\quad 02 / 03 / 99$

(A) $02 / 03 / 99$

(A) $02 / 03 / 99$

(A) $02 / 04 / 99$

A-02

A-03

(A) $02 / 03 / 99$

A-03

(A) $02 / 04 / 99$

(A) $\quad 02 / 03 / 99$

(A) $02 / 04 / 99$

A-04

$37 \quad P-01$

(A) $02 / 08 / 99$

(A) $02 / 08 / 99$

(A) $02 / 08 / 99$

(A) $02 / 08 / 99$

(A) $\quad 02 / 03 / 99$

(A)

02/03/99

(A)

02/03/99

(A) $\quad 02 / 03 / 99$

(A) $02 / 03 / 99$

P-09

P-10

(A) $02 / 03 / 99$
CCTV

$\frac{\text { METHOD }}{\text { WAP }}$

FILE I.D. \#

P990510:07

WAP P990510:08

WAP

P990510:09

WAP

WAP

WAP

WAP

WAP

WAP

WAP

CCTV

WAP

P990511:03

556

WAP

P990511:04

CCTV 556

DP

P990501:01-25

DP

P990502:01-25

DP

DP

WAP

P990511:05

WAP

P990511:06

WAP

P990511:07

WAP

P990511:08

WAP P990511:09

WAP

\section{REMARKS}

Tank condition was normal.

Tank condition was normal.

Tank condition was normal.

Tank condition was normal.

Tank condition was normal.

Tank condition was normal.

Tank condition was normal.

Tank condition was normal.

Tank condition was normal.

Tank condition was normal.

The conductivity probe was deployed at the setpoint.

Tank condition was normal.

The conductivity probe was deployed at the setpoint.

Tank condition was normal.

The conductivity probe was deployed at the setpoint.

Tank condition was normal.

Tank condition was normal.

Tank condition was normal.

Tank condition was normal.

Tank condition was normal.

Tank condition was normal.

Tank condition was normal.

Tank condition was normal.

Tank condition was normal.

Tank condition was normal. 
TANK OR ACCESS OPENING

\begin{tabular}{|c|c|c|c|c|c|c|}
\hline AREA & ANCILLARY & \multicolumn{2}{|c|}{ (A OR I) } & DATE & METHOD & FILE I.D. \\
\hline $\mathbf{H}$ & 37 & P-11 & (A) & $02 / 24 / 99$ & WAP & P990526:01 \\
\hline H & 37 & P.12 & (A) & $02 / 03 / 99$ & WAP & P990511:11 \\
\hline H & 37 & $P-13$ & (A) & $02 / 03 / 99$ & WAP & P990511:12 \\
\hline H & 37 & P-14 & (A) & 02/03/99 & WAP & P990511:13 \\
\hline H & 38 & COP 3 & & $03 / 18 / 99$ & CCTV & 501 \\
\hline
\end{tabular}

H

$38 \quad$ GDL

H

$38 \quad$ LDB-01

H

H

H

H

H

H

H

H

H

H

H

H

H

H

H

H

\section{8}

A-01

A-02

A-02

A-03

A-03

A-04

A-04

38

38

38

38

38

P-04

P.05

P.06

P-07

P-08

P-09
09/17/99

09/17/99

(A)

03/01/99

(A) $03 / 01 / 99$

(A)

03/04/99

(A)

03/01/99

(A)

03/04/99

(A)

03/01/99

(A)

03/04/99

(A)

03/02/99

(A)

03/02/99

(A) $\quad 03 / 02 / 99$

(A) $03 / 02 / 99$

(A) $03 / 01 / 99$

(A)

03/01/99

(A) $03 / 08 / 99$

(A) $03 / 01 / 99$

(A) $03 / 01 / 99$
HELIUM HE-99-011

CCTV $\quad 554$

WAP

P990535:01

WAP P990535:02

CCTV 556

WAP P990535:03

CCTV 556

WAP

CCTV

DP

DP

DP

DP

WAP

WAP

WAP

WAP

WAP

\section{REMARKS}

Tank condition was normal.

Tank condition was normal.

Tank condition was normal.

Tank condition was normal.

Inspection of GDL indicated free of solids. Approximately 22 feet of the GDL were inspected in both directions from the COP.

Hellum tracer testing verifled the integrity of the core pipe of the gravity drain line from 242-16H Evaporator to Tank 38.

The conductivity probe was deployed at the setpoint.

Tank condition was normal.

Tank condition was normal.

The conductivity probe was deployed at the setpoint.

Tank condition was normal.

The conductivity probe was deployed at the setpoint.

Tank condition was normal.

The conductivity probe was deployed at the setpoint.

Tank condition was normal.

Tank condition was normal.

Tank condition was normal.

Tank condition was normal.

Tank condition was normal.

Tank condition was normal.

Tank condition was normal.

Tank condition was normal.

Tank condition was normal. 
TANK OR ACCESS OPENING

\begin{tabular}{|c|c|c|c|c|c|c|c|}
\hline AREA & ANCILLARY & & & DATE & METHOD & FILE I.D. \# & REMARKS \\
\hline $\mathbf{H}$ & 38 & P-10 & (A) & $03 / 01 / 99$ & WAP & P990535:09 & Tank condition was normal. \\
\hline H & 38 & P-11 & (A) & $03 / 01 / 99$ & WAP & P990535:10 & Tank condition was normal. \\
\hline H & 38 & P-12 & (A) & $03 / 01 / 99$ & WAP & P990535:11 & Tank condition was normal. \\
\hline $\mathbf{H}$ & 38 & P-13 & (A) & $03 / 01 / 99$ & WAP & P990535:12 & Tank condition was normal. \\
\hline H & 38 & P-14 & (A) & $03 / 01 / 99$ & WAP & P990535:13 & Tank condition was normal. \\
\hline H & 38 & $\mathbf{G}$ & (I) & $03 / 04 / 99$ & CCTV & 565 & $\begin{array}{l}\text { Documented salt sounding, reel tape } \\
\text { operations, and surface conditions. The } \\
\text { reel tape was operating properly and } \\
\text { nothing adhered to the probe. }\end{array}$ \\
\hline H & 38 & $\mathbf{G}$ & (l) & $03 / 24 / 99$ & CCTV & 565 & $\begin{array}{l}\text { Documented the conditions of the waste } \\
\text { after liquild was added. Inspection revealed } \\
\text { some floating solids and a film/scum on } \\
\text { the supernate surface. }\end{array}$ \\
\hline H & 38 & $\mathbf{G}$ & (l) & $12 / 09 / 99$ & CCTV & 565 & $\begin{array}{l}\text { Documented conditions of the waste } \\
\text { surface after the tank was decanted. The } \\
\text { waste surface was sludge with small pools } \\
\text { of llquid visible. Minimal salt formation } \\
\text { was observed on the cooling colls. }\end{array}$ \\
\hline
\end{tabular}

H

H

(l) $03 / 04 / 99$

CCTV 565

Documented surface conditions. No salt mounding was observed except beneath the C-03 drop riser where the mound height was approximately one foot. The suctlon leg screen on the transfer jet in riser C-01 was visible.

H

38

H

(I)

$03 / 23 / 99$

CCTV

565

H

H

H

H

H

H

H
39

LDB-01

LDB-01

A-01

A-02

A-02

A-03

A-03
06/04/99

$11 / 03 / 99$

(A)

03/01/99

(A)

(A)

$03 / 04 / 99$

(A) $03 / 01 / 99$

(A) $03 / 04 / 99$
CCTV

554

CCTV 554

WAP

P990536:01

WAP

P990536:02

CCTV $\quad 556$

WAP

CCTV
Documented tank interior and surface condition. Inspection revealed some floating solids and a film on the supernate surface.

The conductivity probe was deployed at the setpoint.

The conductivity probe was deployed at the setpoint.

Tank condition was normal.

Tank condition was normal.

The conductivity probe was deployed at the setpoint.

Tank condition was normal.

The conductivity probe was deployed at the setpoint. 


\section{TANK OR ACCESS OPENING}

AREA ANCILLARY

H

$$
39
$$

$$
\text { A.04 }
$$

H

$$
39
$$

A-04

(A OR I)

DATE

(A) 03/01/99

$\frac{\text { METHOD }}{\text { WAP }} \quad \frac{\text { FILE I.D. \# }}{\text { P990536:04 }}$

(A) $03 / 04 / 99 \quad$ CCTV 556

\section{H}

$39 \quad$ P-01

(A) $03 / 01 / 99$

WAP

P990536:05

H

$39 \quad$ P-02

(A) $03 / 02 / 99$

DP P9g0527:01-25

H

39

P.03

(A) $03 / 01 / 99$

WAP P990536:06

H

39

P-04

(A) $03 / 02 / 99$

DP

P990528:01-25

H

39

P-05

(A) $03 / 01 / 99$

WAP

P990536:07

(A) $03 / 10 / 99$

DP

P990541:01-25

(A) $03 / 01 / 99$

WAP

P990536:08

(A) $03 / 01 / 99$

WAP

P990536:09

(A) $03 / 02 / 99$

DP

P990529:01-25

(A) $03 / 02 / 99$

P-10

39

P-11

(A) $03 / 01 / 99$

DP

P990530:01-25

WAP

P990536:10

(A) $03 / 01 / 99$

WAP

P990536:11

(A) $03 / 01 / 99$ WAP

P990536:12

(A)

03/01/99

WAP

P990536:13

02/02/99

CCTV

563

04/28/99

cCTV

587

$07 / 17 / 99$

CCTV

607A

08/06/99

CCTV

607

\section{REMARKS}

Tank condition was normal.

The conductivity probe was deployed at the setpoint.

Tank condition was normal.

Tank condition was normal.

Tank condition was normal.

Tank condition was normal.

Tank condition was normal.

Tank condition was normal.

Tank condition was normal.

Tank condition was normal.

Tank condition was normal.

Tank condition was normal.

Tank condition was normal.

Tank condition was normal.

Tank condition was normal.

Tank condition was normal.

Assisted with leak check valve WTS-V-22 and 27 . Valve 27 was leaking at the valve body.

Assisted with leak check of valves WTS-V-21, 22, 23, 24, 25, 26, 27, and 2009.

Assisted with leak check. Valve WTS-V-22 was verified leak free.

Inspected for leakage. Waste was observed on the floor. Two conductivity probes were observed. One was approximately $11 / 2$ inches off the floor and the other was contacting the floor.

Inspected for leak source observed on $08 / 06 / 99$. Valve WTS-V-23 was observed leaking. 
TANK OR ACCESS OPENING

\begin{tabular}{|c|c|c|c|c|c|c|c|}
\hline AREA & ANCILLARY & $(A$ & & DATE & METHOD & FILE I.D. \# & REMARKS \\
\hline H & 40 & VB & & $08 / 18 / 99$ & CCTV & 607 & $\begin{array}{l}\text { Inspection revealed a leak at the Gray Loc } \\
\text { connection on the north side of Jumper } 23 \text {. } \\
\text { The connector was not closed completely. } \\
\text { The conductivity probes were positioned } \\
\text { one inch above the valve box floor. }\end{array}$ \\
\hline $\mathbf{H}$ & 40 & VB & & $08 / 24 / 99$ & CCTV & 607A & $\begin{array}{l}\text { Inspected for leak source. Valve WTS-V-23 } \\
\text { and } 26 \text { were observed leaking. }\end{array}$ \\
\hline H & 40 & $\dot{\text { v }} \mathrm{B}$ & & $08 / 30 / 99$ & CCTV & $607 A$ & $\begin{array}{l}\text { Assisted with leak check of valves } \\
\text { WTS-V-22,23, and } 26 \text {. Valve WTS-V-22 } \\
\text { leaked, and valves WTS-V-23, \& } 26 \text { were } \\
\text { repaired and leak check performed. Valve } \\
\text { WTS-V-26 was still leaking. }\end{array}$ \\
\hline$H$ & 40 & VB & & $08 / 31 / 99$ & CCTV & 607A & $\begin{array}{l}\text { Assisted with leak check. Valve WTS-V-21 } \\
\text { was leak free and WTS-V-22 was observed } \\
\text { leaking after being repaired. }\end{array}$ \\
\hline$H$ & 40 & VB & & $09 / 01 / 99$ & CCTV & $607 A$ & $\begin{array}{l}\text { Assisted with leak check of valves } \\
\text { WTS-V-22 and } 26 \text {. The valves were leaking. }\end{array}$ \\
\hline$H$ & 40 & VB & & $09 / 03 / 99$ & cctV & 607A & $\begin{array}{l}\text { Assisted with leak check of valves } \\
\text { WTS-V-22 and } 26 . \text { The valves were leak } \\
\text { free. }\end{array}$ \\
\hline H & 40 & $A-01$ & (A) & $05 / 19 / 99$ & WAP & P990574:01 & Tank condition was normal. \\
\hline H & 40 & $A-02$ & (A) & $05 / 19 / 99$ & WAP & P990574:02 & Tank condition was normal. \\
\hline H & 40 & A-02 & (A) & $05 / 26 / 99$ & cctV & 556 & $\begin{array}{l}\text { The conductivity probe was deployed at } \\
\text { the setpoint. }\end{array}$ \\
\hline H & 40 & A-03 & (A) & $05 / 19 / 99$ & WAP & P990574:03 & Tank condition was normal. \\
\hline H & 40 & A-03 & (A) & $05 / 26 / 99$ & $\operatorname{cctV}$ & 556 & $\begin{array}{l}\text { The conductivity probe was deployed at } \\
\text { the setpoint. }\end{array}$ \\
\hline H & 40 & A-04 & (A) & $05 / 19 / 99$ & WAP & P990574:04 & Tank condition was normal. \\
\hline H & 40 & A-04 & (A) & $05 / 26 / 99$ & CCTV & 556 & $\begin{array}{l}\text { The conductivity probe was deployed at } \\
\text { the setpolnt. }\end{array}$ \\
\hline H & 40 & P-01 & (A) & $10 / 01 / 99$ & WAP & P990691:01 & Tank condition was normal. \\
\hline H & 40 & P-02 & (A) & $10 / 01 / 99$ & WAP & P990691:02 & Tank condition was normal. \\
\hline H & 40 & P-03 & (A) & $05 / 19 / 99$ & WAP & P990574:05 & Tank condition was normal. \\
\hline $\mathbf{H}$ & 40 & P-04 & (A) & $08 / 11 / 99$ & DP & P990651:01-25 & Tank condition was normal. \\
\hline H & 40 & P-05 & (A) & $05 / 19 / 99$ & WAP & P990574:06 & Tank condition was normal. \\
\hline H & 40 & P-06 & (A) & $08 / 11 / 99$ & DP & P990652:01-25 & Tank condition was normal. \\
\hline
\end{tabular}




\begin{tabular}{|c|c|c|c|c|c|c|c|}
\hline \multirow{2}{*}{$\frac{\text { AREA }}{H}$} & \multirow{2}{*}{$\begin{array}{c}\text { TANK OR } \\
\text { ANCILLARY } \\
40\end{array}$} & \multicolumn{2}{|c|}{$\frac{\text { ACCESS OPENING }}{(\text { A OR } 1)}$} & \multirow{2}{*}{$\frac{\text { DATE }}{05 / 19 / 99}$} & \multirow{2}{*}{$\frac{\text { METHOD }}{\text { WAP }}$} & \multirow{2}{*}{$\frac{\text { FILE I.D. \# }}{\text { P990574:07 }}$} & \multirow{2}{*}{ Tank condition was normal. } \\
\hline & & P-07 & (A) & & & & \\
\hline H & 40 & P-08 & (A) & $05 / 19 / 99$ & WAP & P990574:08 & Tank condition was normal. \\
\hline $\mathrm{H}$ & 40 & P.09 & (A) & 05/19/99 & WAP & P990574:09 & Tank condition was normal. \\
\hline $\mathrm{H}$ & 40 & P-10 & (A) & $09 / 29 / 99$ & DP & P990689:01-25 & Tank condition was normal. \\
\hline $\mathrm{H}$ & 40 & P.11 & (A) & $05 / 19 / 99$ & WAP & P990574:10 & Tank condition was normal. \\
\hline H & 40 & P-12 & (A) & $05 / 19 / 99$ & WAP & P990574:11 & Tank condition was normal. \\
\hline$H$ & 40 & P-12 & (A) & $07 / 06 / 99$ & WAP & P990636:01 & Tank condition was normal. \\
\hline H & 40 & P-13 & (A) & $05 / 19 / 99$ & WAP & P990574:12 & Tank condition was normal. \\
\hline $\mathbf{H}$ & 40 & P-14 & (A) & $05 / 19 / 99$ & WAP & P990574:13 & Tank condition was normal. \\
\hline $\mathrm{H}$ & 40 & B-05 & (l) & $03 / 11 / 99$ & CCTV & 570 & $\begin{array}{l}\text { Inspected telescoping jet in riser } \mathrm{C}-01 \text {. } \\
\text { Inspection revealed the east deflector was } \\
\text { damaged during installation and } \\
\text { preventing the jet from extending fully. }\end{array}$ \\
\hline H & 40 & B-05 & (l) & $04 / 28 / 99$ & CCTV & 559 & $\begin{array}{l}\text { Inspection revealed the deflector on the } \\
\text { west side of the C-01 riser was operating } \\
\text { properly. }\end{array}$ \\
\hline$H$ & 40 & $B-05$ & (l) & $05 / 13 / 99$ & CCTV & 570 & $\begin{array}{l}\text { Inspection revealed damaged deflector was } \\
\text { successfully removed. }\end{array}$ \\
\hline H & 40 & B-05 & (l) & $10 / 14 / 99$ & CCTV & 570 & $\begin{array}{l}\text { Inspected the } T \mathrm{~T} J \text { in the } \mathrm{C}-01 \text { and found no } \\
\text { obstructions which could prevent } \\
\text { telescoping. }\end{array}$ \\
\hline H & 40 & B-05 & (l) & $10 / 21 / 99$ & CCTV & 625 & $\begin{array}{l}\text { Inspection revealed the jet could not be } \\
\text { lowered due to mechanical problems. }\end{array}$ \\
\hline H & 40 & B-05 & (l) & $10 / 27 / 99$ & CCTV & $625 \& 626$ & $\begin{array}{l}\text { Assisted with the successful lowering of } \\
\text { the } T J \text { and documenting its position in the } \\
\text { tank. }\end{array}$ \\
\hline H & 40 & C-01 & (I) & $07 / 17 / 99$ & CCTV & NA & $\begin{array}{l}\text { Assisted with leak check. TTJ flanges } \\
\text { were observed leak free. }\end{array}$ \\
\hline H & 40 & C-01 & (l) & $10 / 28 / 99$ & CCTV & 626 & $\begin{array}{l}\text { Assisted with leak check the TTJ. No } \\
\text { leakage was observed. }\end{array}$ \\
\hline H & 41 & A-01 & (A) & $05 / 24 / 99$ & WAP & P990575:01 & Tank condition was normal. \\
\hline $\mathbf{H}$ & 41 & A-02 & (A) & $05 / 24 / 99$ & WAP & P990575:02 & Tank condition was normal. \\
\hline $\mathbf{H}$ & 41 & A-02 & (A) & $05 / 25 / 99$ & CCTV & 556 & $\begin{array}{l}\text { The conductivity probe was deployed at } \\
\text { the setpoint. }\end{array}$ \\
\hline
\end{tabular}


TANK OR ACCESS OPENING

\begin{tabular}{|c|c|c|c|c|c|c|}
\hline AREA & ANCILLARY & \multicolumn{2}{|c|}{ (A OR I) } & DATE & METHOD & FILE I.D. \# \\
\hline H & 41 & A-03 & (A) & 05/24/99 & WAP & P990575:03 \\
\hline H & 41 & A-03 & (A) & 05/26/99 & CCTV & 556 \\
\hline H & 41 & A-04 & (A) & 05/24/99 & WAP & P990575:04 \\
\hline H & 41 & A-04 & (A) & 05/26/99 & CCTV & 556 \\
\hline H & 41 & P-01 & (A) & 08/11/99 & DP & P990653:01-24 \\
\hline H & 41 & P.02 & (A) & $07 / 26 / 99$ & DP & P990644:01-25 \\
\hline H & 41 & P.03 & (A) & $07 / 26 / 99$ & DP & P990646:01-25 \\
\hline
\end{tabular}

H

41

P-04

(A) $\quad 07 / 26 / 99$

(A) $05 / 24 / 99$

(A) $\quad 05 / 24 / 99$

(A)

$05 / 24 / 99$

(A) $\quad 05 / 24 / 99$

(A) $\quad 07 / 01 / 99$

P.08

H

H

H

H

H

H

$41 \quad$ P-14
P-09

P-10

P-11

P-12

P-13
(A) $05 / 24 / 99$

(A) $05 / 24 / 99$

(A) $05 / 24 / 99$

(A) $05 / 24 / 99$

(A) $\quad 05 / 24 / 99$
(A) $05 / 24 / 99$
DP

P990647:01-25

WAP

WAP

P990575:06

WAP

WAP

CCTV

WAP

P990575:09

WAP

P990575:10

WAP

WAP

WAP

WAP
REMARKS

Tank condition was normal. Debris was observed on the annulus floor and refractory pad.

The conductivity probe was deployed at the setpoint.

Tank condition was normal.

The conductivity probe was deployed at the setpoint.

Tank condition was normal.

Tank condition was normal. Stains on top of the ventilation duct indicate that water has leaked into the annulus.

Tank condition was normal. Stains on top of the ventilation duct indicate that water had leaked into the annulus. Stains and marks on the annulus floor, beneath the annulus outlet, indicate that water or condensation formed in the outlet had fallen to the floor.

Tank condition was normal. Stains and marks on the annulus floor were caused by water which had leaked into the annulus.

Tank condition was normal.

Tank condition was normal.

Tank condition was normal.

Tank condition was normal.

Inspection revealed stains which indicated water had leaked into the annulus where the IIne designated SP penetrates the annulus near the A-03 rlser.

Tank condition was normal.

Tank condition was normal.

Tank condition was normal.

Tank condition was normal.

Tank condition was normal.

Tank condition was normal. 


\section{TANK OR ACCESS OPENING}

AREA ANCILLARY

H

42

(A OR I)

VB

\section{DATE}

$09 / 16 / 99$

METHOD FILE I.D.\#

CCTV 559

H

42

VB

$09 / 16 / 99$

CCTV

559

H

42

VB

$09 / 17 / 99$

CCTV

559

H

H

H

H

H

H

H

H

H

H

H

H

H

H

H

H

H

H

H
42

A-01

42

A-02

42

42

A-03

42

42

42

A-04

42

P-01

42

42

42

42

P-05

42

P.06

42

P.07

42

42

42

42

42

P-11

P-12
(A)

$05 / 26 / 99$

(A)

05/26/99

(A)

$05 / 26 / 99$

(A)

$05 / 26 / 99$

(A)

05/26/99

(A)

05/26/99

(A)

$09 / 15 / 99$

(A) $08 / 12 / 99$

(A)

08/12/99

(A)

$05 / 26 / 99$

(A)

$05 / 26 / 99$

(A)

05/26/99

(A)

05/26/99

(A)

$05 / 26 / 99$

(A)

05/26/99

(A)

$08 / 12 / 99$

(A)

$08 / 12 / 99$

(A) $05 / 26 / 99$
$05 / 26 / 99$
(A) 
TANK OR ACCESSS OPENING

\begin{tabular}{|c|c|c|c|c|c|c|c|}
\hline AREA & ANCILLARY & (A & l) & DATE & METHOD & FILE I.D. \# & REMARKS \\
\hline H & 42 & P-13 & (A) & $05 / 26 / 99$ & WAP & P990580:12 & Tank condition was normal. \\
\hline H & 42 & P-14 & (A) & $05 / 26 / 99$ & WAP & P990580:13 & Tank condition was normal. \\
\hline H & 42 & B-02 & (l) & 07/30/99 & CCTV & 603 & $\begin{array}{l}\text { Inspection of the tank interior revealed } \\
\text { sludge mounding above the liquid level. }\end{array}$ \\
\hline H & 42 & C-03 & (l) & 07/30/99 & CCTV & 603 & $\begin{array}{l}\text { Inspection of the tank interior revealed } \\
\text { sludge mounding above the liquid level. }\end{array}$ \\
\hline H & 43 & 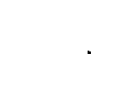 & & 09/17/99 & HELIUM & HE-99-012 & $\begin{array}{l}\text { Helium tracer testing verifled the integrity } \\
\text { of the overheads transfer line from the } \\
242-16 \mathrm{H} \text { evaporator to Tank } 43 \text {. }\end{array}$ \\
\hline H & 43 & LDB-01 & & $07 / 15 / 99$ & CCTV & 554 & $\begin{array}{l}\text { The conductivity probe was deployed at } \\
\text { the setpoint. }\end{array}$ \\
\hline H & 43 & LDB-04 & & $03 / 24 / 99$ & CCTV & 554 & $\begin{array}{l}\text { The conductivity probe was deployed at } \\
\text { the setpoint. }\end{array}$ \\
\hline H & 43 & LDB-07 & & $03 / 18 / 99$ & CCTV & 554 & $\begin{array}{l}\text { The conductivity probe was deployed at } \\
\text { the setpoint. }\end{array}$ \\
\hline H & 43 & LDB-07 & & 03/18/99 & HELIUM & HE-99-003 & $\begin{array}{l}\text { Hellum tracer testing verifled the integrity } \\
\text { of the overheads transfer line from the } \\
242-16 \mathrm{H} \text { evaporator to Tank } 43 \text {. }\end{array}$ \\
\hline H & 43 & LDB-07 & & $09 / 17 / 99$ & CCTV & 554 & $\begin{array}{l}\text { The conductivity probe was deployed at } \\
\text { the setpoint. }\end{array}$ \\
\hline $\mathbf{H}$ & 43 & A-01 & (A) & 03/01/99 & WAP & P990537:01 & Tank condition was normal. \\
\hline $\mathrm{H}$ & 43 & A-02 & (A) & 03/01/99 & WAP & P990537:02 & Tank condition was normal. \\
\hline H & 43 & $A-02$ & (A) & $03 / 04 / 99$ & CCTV & 556 & $\begin{array}{l}\text { The conductivity probe was deployed at } \\
\text { the setpoint. }\end{array}$ \\
\hline H & 43 & A-03 & (A) & $03 / 04 / 99$ & CCTV & 556 & $\begin{array}{l}\text { The conductivity probe was deployed at } \\
\text { the setpoint. }\end{array}$ \\
\hline$H$ & 43 & $A-03$ & (A) & 03/08/99 & WAP & P990544:04 & Tank condition was normal. \\
\hline H & 43 & $A-04$ & (A) & 03/01/99 & WAP & P990537:03 & Tank condition was normal. \\
\hline H & 43 & $A-04$ & (A) & $03 / 04 / 99$ & CCTV & 556 & $\begin{array}{l}\text { The conductivity probe was deployed at } \\
\text { the setpoint. }\end{array}$ \\
\hline H & 43 & P-01 & (A) & $03 / 02 / 99$ & DP & P990538:01-25 & Tank condition was normal. \\
\hline H & 43 & P-02 & (A) & $03 / 02 / 99$ & DP & P990539:01-25 & Tank condition was normal. \\
\hline H & 43 & $P-03$ & (A) & $03 / 10 / 99$ & DP & P990542:01-25 & Tank condition was normal. \\
\hline H & 43 & P-04 & (A) & $03 / 02 / 99$ & DP & P990540:01-25 & Tank condition was normal. \\
\hline
\end{tabular}


TANK OR ACCESS OPENING

\begin{tabular}{|c|c|c|c|c|c|c|}
\hline AREA & ANCILLARY & \multicolumn{2}{|c|}{ (A OR I) } & DATE & METHOD & FILE I.D. \# \\
\hline H & 43 & P-05 & (A) & 03/01/99 & WAP & P990537:04 \\
\hline$H$ & 43 & P-06 & (A) & 03/08/99 & WAP & P990544:02 \\
\hline H & 43 & P-07 & (A) & 03/08/99 & WAP & P990544:03 \\
\hline H & 43 & $P-08$ & (A) & 03/08/99 & WAP & P990544:05 \\
\hline H & 43 & P.09 & (A) & 03/08/99 & WAP & P990544:01 \\
\hline
\end{tabular}

H

H

H

H

H

H

H

$43 \quad \mathrm{H}$

H

43

H

C-01

H

(I)

$01 / 13 / 99$

(A) $03 / 01 / 99$

(A) $03 / 01 / 99$

(I) $11 / 15 / 99$

(I) $11 / 18 / 99$

CCTV

635

CCTV $\quad 558$

$\mathbf{F}$

44

LDB-02

$\mathbf{F}$

44

A-01

(A)

$06 / 28 / 99$

P990631:01

\section{REMARKS}

Tank condition was normal.

Tank condition was normal.

Tank condition was normal.

Tank condition was normal.

Tank condition was normal. Stains and marks on the ventilation duct and annulus floor were caused by water which had leaked into the annulus.

Tank condition was normal.

Tank condition was normal.

Tank condition was normal.

Tank condition was normal.

Tank condition was normal.

Inspection revealed a leak at the cam locks for the $\pi$ J.

Inspection revealed that the jet was leak free after the gaskets were replaced at the cam locks.

Documented surface conditions. Inspection revealed very little organic material on the surface. Two small masses were observed floating on the surface. The reel tape and cooling colls appeared to be covered by a thin "oily" residue.

Assisted in obtaining an organic sample and to document surface conditions. A thin transparent fllm was noted on the liquid surface with a few floating solids.

The conductivity probe was deployed at the setpoint. A small amount of debris was observed beneath the probe.

Tank condition was normal. Stains and marks on the secondary vessel wall were caused by water which had leaked into the annulus. A masselin cloth was observed on the annulus floor.

The conductivity probe was deployed at the setpoint. 


\section{TANK OR ACCESS OPENING}

\begin{tabular}{|c|c|c|c|c|c|c|}
\hline AREA & ANCILLARY & \multicolumn{2}{|c|}{ (A OR I) } & DATE & METHOD & FILE I.D. \\
\hline $\mathbf{F}$ & 44 & A-02 & (A) & $06 / 28 / 99$ & WAP & P990631:02 \\
\hline $\mathbf{F}$ & 44 & A-03 & (A) & 05/26/99 & CCTV & 556 \\
\hline $\mathbf{F}$ & 44 & A-03 & (A) & $06 / 28 / 99$ & WAP & P990631:03 \\
\hline $\mathbf{F}$ & 44 & A-04 & (A) & $05 / 26 / 99$ & cctv & 556 \\
\hline $\mathbf{F}$ & 44 & A-04 & (A) & $06 / 28 / 99$ & WAP & P990631:04 \\
\hline & & & - &.$\cdot \cdot$ & - & \\
\hline $\mathbf{F}$ & 44 & P.01 & (A) & 06/29/99 & WAP & P990635:01 \\
\hline $\mathbf{F}$ & 44 & P.02 & (A) & $06 / 29 / 99$ & WAP & P990635:02 \\
\hline
\end{tabular}

$\mathbf{F}$

$F$

$\mathbf{F}$

$\mathbf{F}$

$F$

F

$\mathbf{F}$

$44 \quad P-10$

F $\quad 44 \quad P-11$

$\mathbf{F}$

$\mathbf{F}$

$\mathbf{F}$
$44 \quad$ P-08

(A)

06/28/99

(A)

(A)

(A)

P-12

(A)

(A) $06 / 28 / 99$

P-13

(A)
06/28/99

06/28/99

06/28/99

06/28/99

06/28/99
P.14
44
(A) $05 / 28 / 99$

DP

DP

DP

DP

DP

WAP

WAP

WAP

WAP

WAP

WAP

WAP

\section{REMARKS}

Tank condition was normal. Stains and marks on the secondary vessel wall were caused by water which had leaked into the annulus.

The conductivity probe was deployed at the setpoint.

Tank condition was normal.

The conductivity probe was deployed at the setpoint.

Tank condition was normal. Stains and marks on the secondary vessel wall were caused by water which had leaked into the annulus.

Tank condition was normal.

Tank condition was normal. Stains and marks on the secondary vessel wall were caused by water which had leaked into the annulus . A masselin cloth was observed on the annulus floor.

Tank condition was normal.

Tank condition was normal.

Tank condition was normal.

Tank condition was normal.

Tank conditlon was normal. Calciferous deposits on the secondary vessel wall have increased since inspected on 6/20/95.

Tank condition was normal.

Tank condition was normal.

Tank condition was normal.

Tank condition was normal.

Tank condition was normal.

Tank condition was normal.

Tank condition was normal. 
TANK OR ACCESS OPENING

AREA ANCILLARY

\begin{tabular}{|c|c|c|c|c|c|c|}
\hline$F$ & 44 & $\mathbf{G}$ & (I) & $04 / 27 / 99$ & CCTV & 578 \\
\hline$F$ & 44 & $\mathbf{G}$ & (I) & $08 / 26 / 99$ & CCTV & 610 \\
\hline
\end{tabular}

F

44

G

(I) $\quad 12 / 07 / 99$

CCTV

559

F

45

LDB-02

F

45

LDB-02

F

45

LDB-03

$\boldsymbol{F}$

F

F

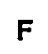

F

F

$\mathbf{F}$

F

$\mathbf{F}$

$\mathbf{F}$

$\mathbf{F}$

$\mathbf{F}$

$\mathbf{F}$

(A) $06 / 28 / 99$

A-02

(A) $05 / 26 / 99$

CCTV

556

(A) $06 / 28 / 99$

WAP

P990632:02

(A) $05 / 26 / 99$

cctV

556

(A) $06 / 28 / 99$

WAP

P990632:03

(A) $05 / 26 / 99$

CCTV 556

$$
\text { A-04 }
$$

A-04

(A) $06 / 28 / 99$

WAP

P990632:04

WAP

P990701:01

(A) $12 / 02 / 99$

(A) $\quad 06 / 28 / 99$

WAP

P990632:05

(A) $06 / 28 / 99$

WAP

P990632:06

(A) $05 / 28 / 99$

DP

P990601:01-24

(A) $05 / 28 / 99$

DP

P990602:01-23

P.04

P-05

(A) $05 / 28 / 99$

DP P990603:01-25

\section{REMARKS}

Inspection revealed that the surface below the $G$ riser was salt with no liquid visible. The surface was llquid at other locations in the tank.

Investigated malfunction of the reel tape. The reel tape was embedded in the salt crystals. The waste surface was salt with some small pools of liquid.

Observed and documented flushing and removing of old reel tape and to ensure proper operation of newly installed reel tape.

Positioned the conductivity probe in the LDB at the setpoint.

The conductivity probe was deployed at the setpoint.

The conductivity probe was deployed at the setpoint.

Tank condition was normal.

The conductivity probe was deployed at the setpoint.

Tank condition was normal.

The conductivity probe was deployed at the setpoint.

Tank condition was normal.

The conductivity probe was deployed at the setpoint.

Tank condition was normal.

Tank condition was normal.

Tank condition was normal.

Tank condition was normal.

Tank condition was normal.

Tank condition was normal. Stains and marks on the secondary vessel wall were caused by water which had leaked into the annulus.

Tank condition was normal. 
TANK OR ACCESS OPENING AREA ANCILLARY

\begin{tabular}{|c|c|c|c|c|c|c|}
\hline AREA & ANCILLARY & (A & & DATE & METHOD & FILE I.D. \# \\
\hline$F$ & 45 & P-06 & (A) & $05 / 28 / 99$ & DP & P990604:01-25 \\
\hline F & 45 & P-07 & (A) & $05 / 28 / 99$ & DP & P990605:01-21 \\
\hline $\mathbf{F}$ & 45 & P-08 & (A) & $06 / 28 / 99$ & WAP & P990632:07 \\
\hline $\mathbf{F}$ & 45 & P-09 & (A) & $06 / 28 / 99$ & WAP & P990632:08 \\
\hline $\mathbf{F}$ & 45 & P-10 & (A) & $06 / 28 / 99$ & WAP & P990632:09 \\
\hline F & 45 & P-11 & (A) & $06 / 28 / 99$ & WAP & P990632:10 \\
\hline $\mathbf{F}$ & 45 & P-12 & (A) & $06 / 28 / 99$ & WAP & P990632:11 \\
\hline $\mathbf{F}$ & 45 & P-13 & (A) & $06 / 28 / 99$ & WAP & P990632:12 \\
\hline $\mathbf{F}$ & 45 & P-14 & (A) & $06 / 28 / 99$ & WAP & P990632:13 \\
\hline $\mathbf{F}$ & 46 & LDB-01 & & $11 / 29 / 99$ & CCTV & 554 \\
\hline $\mathbf{F}$ & 46 & LDB-01 & & $12 / 01 / 99$ & CCTV & 554 \\
\hline $\mathbf{F}$ & 46 & LDB-02 & & $01 / 13 / 99$ & CCTV & 554 \\
\hline $\mathbf{F}$ & 46 & LDB-02 & & $01 / 19 / 99$ & CCTV & 554 \\
\hline F & 46 & LDB-02 & & $03 / 05 / 99$ & CCTV & 554 \\
\hline $\mathbf{F}$ & 46 & LDB-02 & & $11 / 29 / 99$ & CCTV & 554 \\
\hline $\mathbf{F}$ & 46 & LDB-02 & & $12 / 01 / 99$ & CCTV & 554 \\
\hline $\mathbf{F}$ & 46 & LDB-03 & & 03/06/99 & CCTV & 554 \\
\hline $\mathbf{F}$ & 46 & LDB-04 & & 03/29/99 & CCTV & 554 \\
\hline
\end{tabular}

$F$
$F$
$F$
$F$
$F$
$F$
$F$
$F$
$F$
$F$
$F$ 
TANK OR ACCESS OPENING

\begin{tabular}{|c|c|c|c|c|c|c|}
\hline AREA & ANCILLARY & \multicolumn{2}{|c|}{ (A OR I) } & DATE & METHOD & FILE I.D. \# \\
\hline$F$ & 46 & A-02 & (A) & $05 / 26 / 99$ & CCTV & 556 \\
\hline$F$ & 46 & A-03 & (A) & $05 / 06 / 99$ & WAP & P990576:03 \\
\hline $\mathbf{F}$ & 46 & A-03 & (A) & $05 / 26 / 99$ & CCTV & 556 \\
\hline $\mathbf{F}$ & 46 & A- 04 & (A) & $05 / 06 / 99$ & WAP & P990576:04 \\
\hline $\mathbf{F}$ & 46 & $A-04$ & (A) & 05/26/99 & CCTV & 556 \\
\hline $\mathbf{F}$ & 46 & P-01 & (A) & $05 / 06 / 99$ & WAP & P990576:05 \\
\hline
\end{tabular}

$\mathbf{F}$

$\mathbf{F}$

46

P-04

(A) $\quad 05 / 28 / 99$

F

F

$\mathbf{F}$

$\mathbf{F}$

46

P-07

(A)

07/06/99

CCTV

559

F

46

P-08

(A)

05/06/99

WAP

P990576:07

F

$\mathbf{F}$
46

46
P-09

P-10
(A) $05 / 06 / 99$

(A) $05 / 06 / 99$
WAP

WAP

\section{REMARKS}

The conductivity probe was deployed at the setpoint.

Tank condition was normal.

The conductivity probe was deployed at the setpoint.

Tank condition was normal.

The conductivity probe was deployed at the setpoint.

Tank condition was normal. Stains and marks on the ventilation duct and annulus floor had increased due to water which had leaked into the annulus.

Tank condition was normal.

Tank condition was normal. Calciferous deposits on the secondary vessel wall have increased since inspected on 6/15/95.

Tank condition was normal. Calciferous deposits on the secondary vessel wall have increased since inspected on 6/15/95.

Tank condition was normal.

Tank condition was normal.

Tank condition was normal. Stains and marks on the ventilation duct and annulus floor were caused by water which had leaked into the annulus. Mild surface corrosion was observed on the annulus floor.

Determined source of Inleakage. The stains on the secondary vessel wall were from water which had leaked between the cover plate and the top of the secondary vessel wall.

Tank condition was normal. Stains and marks on the ventilation duct and annulus floor were caused by water which had leaked into the annulus.

Tank condition was normal.

Tank condition was normal. Calciferous deposits on the secondary vessel wall have increased since inspected on 5/15/98. 


\begin{tabular}{|c|c|c|c|c|c|c|c|}
\hline \multirow{2}{*}{$\frac{\text { AREA }}{F}$} & \multirow{2}{*}{$\begin{array}{c}\begin{array}{c}\text { TANK OR } \\
\text { ANCILLARY }\end{array} \\
46\end{array}$} & \multicolumn{2}{|c|}{$\frac{\text { ACCESS OPENING }}{(\text { A OR I) }}$} & \multirow{2}{*}{$\frac{\text { DATE }}{05 / 06 / 99}$} & \multirow{2}{*}{$\frac{\text { METHOD }}{\text { WAP }}$} & \multirow{2}{*}{$\frac{\text { FILE I.D. \# }}{\text { P990576:10 }}$} & \multirow{2}{*}{ Tank condition was normal. } \\
\hline & & P-11 & (A) & & & & \\
\hline $\mathbf{F}$ & 46 & P-12 & (A) & $05 / 06 / 99$ & WAP & P990576:11 & Tank condition was normal. \\
\hline $\mathbf{F}$ & 46 & P-12 & (A) & $07 / 06 / 99$ & CCTV & 559 & $\begin{array}{l}\text { Identified a plastic respirator bag observed } \\
\text { on the annulus floor. }\end{array}$ \\
\hline $\boldsymbol{F}$ & 46 & P-13 & (A) & $05 / 06 / 99$ & WAP & P990576:12 & Tank condition was normal. \\
\hline $\mathbf{F}$ & 46 & P-14 & (A) & $05 / 06 / 99$ & WAP & P990576:13 & Tank condition was normal. \\
\hline $\mathbf{F}$ & 46 & $\mathbf{H}$ & (I) & $03 / 06 / 99$ & CCTV & 567 & $\begin{array}{l}\text { Steam and liquid was observed leaking } \\
\text { from the jet in riser } \mathrm{C}-01 \text {. }\end{array}$ \\
\hline $\mathbf{F}$ & 47 & LDB-01 & & $03 / 29 / 99$ & cCTV & 554 & $\begin{array}{l}\text { The conductivity probe was deployed at } \\
\text { the setpoint. }\end{array}$ \\
\hline $\mathbf{F}$ & 47 & LDB-02 & & $03 / 06 / 99$ & cctV & 554 & $\begin{array}{l}\text { The conductivity probe was deployed at } \\
\text { the setpoint. }\end{array}$ \\
\hline $\mathbf{F}$ & 47 & LDB-03 & & $03 / 06 / 99$ & CCTV & 554 & $\begin{array}{l}\text { The conductivity probe was deployed at } \\
\text { the setpoint. }\end{array}$ \\
\hline $\mathbf{F}$ & 47 & LDB-03 & & $04 / 27 / 99$ & CCTV & 554 & $\begin{array}{l}\text { The conductivity probe was deployed at } \\
\text { the setpoint. }\end{array}$ \\
\hline $\mathbf{F}$ & 47 & LDB-03 & & $05 / 20 / 99$ & CCTV & 554 & $\begin{array}{l}\text { The conductivity probe was deployed at } \\
\text { the setpoint. }\end{array}$ \\
\hline $\mathbf{F}$ & 47 & A-01 & (A) & $05 / 06 / 99$ & WAP & P990577:01 & Tank condition was normal. \\
\hline $\mathbf{F}$ & 47 & A-02 & (A) & $05 / 06 / 99$ & WAP & P990577:02 & Tank condition was normal. \\
\hline $\mathbf{F}$ & 47 & A-02 & (A) & $05 / 26 / 99$ & CCTV & 556 & $\begin{array}{l}\text { The conductivity probe was deployed at } \\
\text { the setpoint. }\end{array}$ \\
\hline $\mathbf{F}$ & 47 & A-03 & (A) & $05 / 06 / 99$ & WAP & P990577:03 & Tank condition was normal. \\
\hline $\mathbf{F}$ & 47 & A-03 & (A) & $05 / 26 / 99$ & CCTV & 556 & $\begin{array}{l}\text { The conductivity probe was deployed at } \\
\text { the setpoint. }\end{array}$ \\
\hline $\mathbf{F}$ & 47 & A-04 & (A) & $05 / 06 / 99$ & WAP & P990577:04 & $\begin{array}{l}\text { Tank condition was normal. A riser plug } \\
\text { gasket was observed on the ventllation } \\
\text { duct. }\end{array}$ \\
\hline
\end{tabular}


TANK OR ACCESS OPENING

$\frac{\text { AREA }}{F} \frac{\text { ANCILLARY }}{47} \frac{\frac{(A \text { OR I) }}{\text { A-04 }} \quad \text { (A) } 05 / 26 / 99}{\text { CCTV }} \frac{\text { MATE }}{556}$$$
\text { F }
$$

$F$

$\mathbf{F}$

$\mathbf{F}$

$\mathbf{F}$

$\boldsymbol{F}$

$\mathbf{F}$

F

$\mathbf{F}$

F

F

F

$\mathbf{F}$

$\boldsymbol{F}$

$\mathbf{F}$

H

H

H

H
47

P-06

(A)

05/28/99

(A)

$05 / 28 / 99$

(A)

05/06/99

(A)

05/06/99

(A)

05/06/99

(A)

05/06/99

(A)

05/06/99

(A)

05/06/99

(A)

05/06/99

(A)

09/28/99

A-01

48

A-02

(A)

$03 / 15 / 99$

(A)

$04 / 22 / 99$

A-02

48

A-03

(A)

$03 / 15 / 99$

(A)

04/22/99

48 A-03
DP

P990611:01-25

WAP P990577:05

WAP P990577:06

DP

DP

DP

P990638:01-25

DP

P990612:01-22

WAP P990577:07

WAP P990577:08

WAP

P990577:09

WAP

P990577:10

WAP

WAP

WAP

P990577:13

WAP

P990688:01

WAP

P990548:01

CCTV 556

WAP

P990548:02

CCTV 556

\section{REMARKS}

The conductivity probe was deployed at the setpoint.

Tank condition was normal.

Tank condition was normal.

Tank condition was normal.

Tank condition was normal. An absorbent swipe was observed on the annulus floor.

Tank condition was normal. Chromate deposits on the primary vessel wall and annulus floor have increased since inspected on $05 / 25 / 95$.

Tank condition was normal. Chromate deposits on the primary vessel wall and annulus floor have increased since inspected on 05/25/95.

Tank condition was normal. A masselin cloth was observed on the annulus floor.

Tank condition was normal.

Tank condition was normal.

Tank condition was normal.

Tank condition was normal.

Tank condition was normal.

Tank condition was normal.

Tank condition was normal.

Tank condition was normal. Stains and marks on the primary vessel wall, secondary vessel wall, and the annulus floor indicated water has leaked into the annulus.

Tank condition was normal.

The conductivity probe was deployed at the setpoint.

Tank condition was normal.

The conductivity probe was deployed at the setpoint. 
TANK OR ACCESS OPENING AREA ANCILLARY$$
\text { H }
$$

H

H

H

H

H

H

H

H

H

H

H

H

H

H

H

H

H

H

H

H

H

48

A-0
(A OR I)

48

$$
\text { A-04 }
$$

48

P-01

48

P-02

48

P-03

P-04

P-05

P-06

48

48

P-07

P-08

P-09

P-10

P-11

48

48

P-13

48

P-14

H

49

A-01

49

A-02

49

A-02

49

A-03

49

A-03

49

A-04

49

A-04

\section{DATE}

(A) $03 / 15 / 99$

(A) $04 / 22 / 99$

(A) $03 / 15 / 99$

(A) $03 / 15 / 99$

(A) $04 / 13 / 99$

(A) $04 / 15 / 99$

(A) $\quad 04 / 15 / 99$

(A) $03 / 15 / 99$

(A) $03 / 15 / 99$

(A) $03 / 15 / 99$

(A) $03 / 15 / 99$

(A) $04 / 15 / 99$

(A) $03 / 15 / 99$

(A) $03 / 15 / 99$

(A) $09 / 28 / 99$

(A)

03/10/99

(A) $03 / 10 / 99$

(A) $04 / 22 / 99$

(A) $03 / 10 / 99$

(A) $04 / 22 / 99$

(A) $03 / 10 / 99$

(A) $04 / 22 / 99$
METHOD

FILE 1.D. \#

P990548:03

CCTV $\quad 556$

WAP

P990548:04

WAP

P990548:05

DP

P990553:01-25

DP

P990593:01-24

DP P990594:01-25

WAP

P990548:06

WAP

P990548:07

WAP P990548:08

WAP P990548:09

DP

P990595:01-25

WAP

P990548:10

WAP

P990548:11

WAP

P990688:02

P990545:01

P990545:02

CCTV $\quad 556$

WAP P990545:03

CCTV $\quad 556$

WAP P990545:04

CCTV 556

\section{REMARKS}

Tank conditlon was normal.

The conductivity probe was deployed at the setpoint.

Tank condition was normal.

Tank condition was normal. A masselin cloth was observed on the annulus floor.

Tank condition was normal.

Tank condition was normal.

Tank condition was normal.

Tank condition was normal.

Tank condition was normal.

Tank condition was normal.

Tank condition was normal.

Tank condition was normal.

Tank condition was normal.

Tank condition was normal.

Tank condition was normal. Stains and marks on the primary vessel wall, secondary vessel wall, and the annulus floor indicated water has leaked into the annulus.

Tank condition was normal.

Tank condition was normal.

The conductivity probe was deployed at the setpoint.

Tank condition was normal.

The conductivity probe was deployed at the setpoint.

Tank conditlon was normal.

The conductivity probe was deployed at the setpoint. 
TANK OR ACCESS OPENING AREA ANCILLARY

H

(n)

$$
\text { H }
$$

$$
\text { H }
$$

$H$

H

H

H

H

H

H

H

$49 \quad \mathrm{C}-03$

$01 / 19 / 99$

$-\mathrm{H}^{-} \quad-4^{--9^{-}}-\mathrm{C}_{-03}-$

H

49

C-03

(l)

$10 / 11 / 99$

CCTV

623

H

49

G

(l)

01/19/99

CCTV

558

\section{H}

49

G

(l) $01 / 19 / 99$

CCTV $\quad 558$

CCTV 623

(2)

FILE I.D. \#

P990545:05

P990545:06

P990554:01-24

P990555:01-25

P990556:01-25

P990557:01-25

P990558:01-25

P990545:07

P990545:08

P990545:09

P990545:10

P990545:11

P990545:12

P990545:13

301

(

CCTV 301


TANK OR ACCESS OPENING

\begin{tabular}{|c|c|c|c|c|c|c|}
\hline AREA & ANCILLARY & & l) & DATE & METHOD & FILE I.D.\# \\
\hline H & 49 & $\mathbf{G}$ & (l) & $10 / 11 / 99$ & CCTV & 623 \\
\hline
\end{tabular}

Documented the waste surface condition.

The waste surface was damp salt with pools of liquid visible beneath several access risers.

\begin{tabular}{|c|c|c|c|c|c|c|c|}
\hline H & 50 & $A-01$ & (A) & $03 / 15 / 99$ & WAP & P990549:01 & Tank condition was normal. \\
\hline $\mathbf{H}$ & 50 & A-02 & (A) & $03 / 15 / 99$ & WAP & P990549:02 & Tank condition was normal. \\
\hline H & 50 & A-02 & (A) & $04 / 12 / 99$ & CCTV & 556 & $\begin{array}{l}\text { The conductivity probe was deployed at } \\
\text { the setpoint. }\end{array}$ \\
\hline H & 50 & A-03 & (A) & $03 / 15 / 99$ & WAP & P990549:03 & Tank condition was normal. \\
\hline H & $50^{\circ}$ & A-03 & (A) & $04 / 12 / 99$ & CCTV & 556 & $\begin{array}{l}\text { The conductivity probe was deployed at } \\
\text { the setpoint. }\end{array}$ \\
\hline H & 50 & A-04 & (A) & $03 / 15 / 99$ & WAP & P990549:04 & Tank condition was normal. \\
\hline H & 50 & A-04 & (A) & $04 / 12 / 99$ & CCTV & 556 & $\begin{array}{l}\text { The conductivity probe was deployed at } \\
\text { the setpoint. }\end{array}$ \\
\hline
\end{tabular}

H

H

H

50

P-01

(A)

03/15/99

(A)

$03 / 15 / 99$

(A) $04 / 12 / 99$

P-03

50

\begin{abstract}
50
\end{abstract}
P-04

(A)

$04 / 12 / 99$

(A) $04 / 12 / 99$

P-05

50

$04 / 12 / 99$

H

50

H

50

P-06

P-07

(A)

$04 / 12 / 99$

(A) $09 / 29 / 99$

H

H

$$
\text { H. }
$$

H

H

50
P-08

(A)

$03 / 15 / 99$

(A)

03/15/99

(A) $03 / 15 / 99$

(A) $03 / 15 / 99$

P-11

P-12
DP

P990562:01-25

DP

P990690:01-25

WAP

WAP

DP

P990559:01-24

DP

P990560:01-25

P990561:01-25

DP

DP

P990690:01-25

Tank condition was normal.

Tank condition was normal.

Tank condition was normal. Marks and deposits on the primary vessel wall were caused by water which had leaked Into the annulus.

Tank condition was normal.

Tank condition was normal. Stains and marks on the secondary vessel wall were caused by water which had leaked into the annulus.

Tank condition was normal.

Tank condition was normal. The refractory pad steel band and approximately 4 inches of the bottom of the ventilation duct appears to be wet.

Tank condition was normal.

Tank condition was normal.

Tank condition was normal.

Tank condition was normal.

Tank condition was normal. 
TANK OR ACCESS OPENING

AREA ANCILLARY

H

H

H

H

H

H

H

H

H

H

H

H

H

H

H

H

H

H

50

51

51

51

51

51

51

51

51

51

51

51

51

51

51

$\frac{(A}{P-13}$

VB

VB

A-01

A-02

A-02

A-03

A-03

A-04

A-04

P-01

P-02

P-03

P-04

P.05

(A)

09/16/99

CCTV

09/16/99

CCTV

(A)

$03 / 22 / 99$

02/08/99

(A)

02/08/99

(A)

$03 / 22 / 99$

(A)

03/22/99

(A)

02/08/99

(A)

02/08/99

(A)

03/22/99

(A)

03/22/99

(A) $08 / 17 / 99$

(A) $08 / 16 / 99$

(A) $08 / 16 / 99$
559

559

DP

P990659:01-25

FILE I.D. \#

P990549:12

P990549:13

NA

P990550:01

CCTV $\quad 556$

WAP P990512:01

CCTV $\quad 556$

WAP

CCTV $\quad 556$

WAP

P990512:02

P990550:03

P990550:04

P990662:01-25

DP P990658:01-25
REMARKS

Tank condition was normal.

Tank condition was normal.

Inspection of the conduit from the gang valve house south of Tank 51 revealed dirt inside the line approximately $81 / 2$ to $83 / 4$ feet from the open end.

The conductivity probe was deployed at the setpoint.

The conductivity probe was deployed at the setpoint.

Tank condition was normal.

The conductivity probe was deployed at the setpoint.

Tank condition was normal.

The conductivity probe was deployed at the setpoint.

Tank condition was normal.

The conductivity probe was deployed at the setpoint.

Tank condition was normal.

Tank condition was normal.

Tank condition was normal.

Tank condition was normal.

Tank condition was normal. A masselln cloth was observed on the annulus floor.

Tank condition was normal. The primary vessel wall was wet. Stains and deposits observed on the wall indicated that chromated cooling water had leaked into the annulus.

Inspection for dampness after cooling coil \#7 had been valved off revealed the areas were dry. 
TANK OR ACCESS OPENING AREA ANCILLARY

H

51 (A OR I)

\section{.}

DATE

(A)

$08 / 16 / 99$

$\frac{\text { METHOD }}{\text { DP }}$

FILE 1.D. \#

P990660:01-25

H

51

P-06

(A)

$11 / 16 / 99$

CCTV

559

H

H

H

H
H

$H$

H

H

F

H

H

H

H

CTS Underliner

Sump

(A)

(A)

$03 / 22 / 99$

(A)

03/22/99

(A)

03/22/99

(A)

02/08/99

(A)

02/08/99

(A)

02/08/99

(A)

03/22/99

(l)

$04 / 21 / 99$

NA

04/27/99

CCTV

559

06/09/99

CCTV

589

02/09/99

CCT

554

01/22/99

Underliner

Sump

CTS

Underliner

Sump

F

DB-01
07/22/99

CCTV

\section{REMARKS}

Tank condition was normal. The primary vessel wall was wet. Stains and deposits observed on the wall indicated that chromated cooling water had leaked into the annulus.

Inspection for dampness after cooling coll \#7 had been valved off revealed the areas were dry.

Tank condition was normal.

Tank condition was normal.

Tank condition was normal.

Tank condition was normal.

Tank condition was normal.

Tank condition was normal.

Tank condition was normal.

Tank condition was normal.

Verifled the discharge connector was located on the south side inside the riser opening.

Vlewing of backflush valve during transfer revealed the valve was not leaking.

Documented the conditions in the CTS.

Water was observed in the sump area only.

The conductivity probe was deployed at the setpoint.

Inspection revealed the standpipe contained water and debris.

Documented the conditions in the underliner sump and aided with attempts to remove the debris.

Monitored flushing and pumping out water in preparation to install the conductivity probe. Debris, Including steel tubing, plastic tubing, hose clamps and a crescent wrench were observed.

Provided video support for remote removal of jumpers and installation of dummies. Made videotape to document the final equipment configuration. 
TANK OR ACCESS OPENING

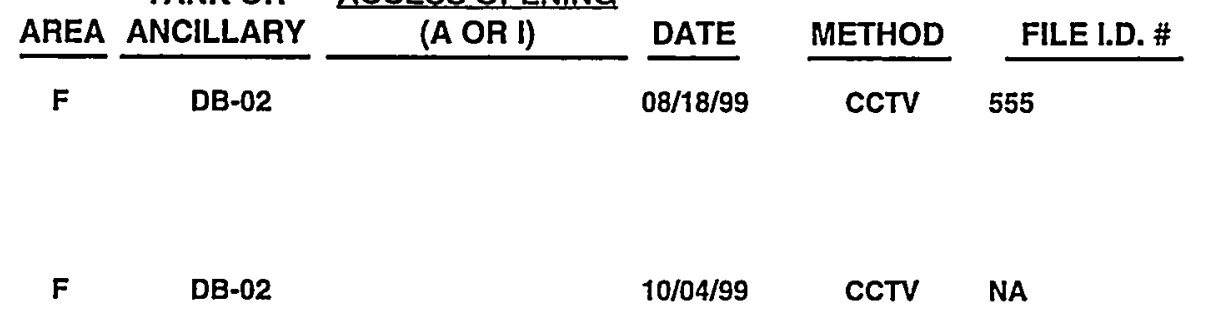
DB-02

F

$\mathbf{F}$

$\mathbf{F}$

$\mathbf{F}$

$\mathbf{F}$

$\mathbf{F}$

F

F

$F$

$F$

F

$\mathbf{F}$

$\mathbf{F}$

F

DB-02

DB-02

DB-02

LDB-01

DB-02

LDB-02

DB-02

LDB-02

DB-02

LDB-02

DB-02

LDB-12

DB-02

MLDB-01

DB-02

MLDB-01

DB-02

MLDB-01

DB-02

MLDB-02

DB-02

MLDB-02

06/09/99

CCTV

NA

$\begin{array}{lllll}\text { DB-02 } & \text { MLDB-02 } & \text { 06/10/99 } & \text { HELIUM HE-99-009 } \\ \text { DB-02 } & \text { MLDB-02 } & 12 / 16 / 99 & \text { CCTV } & 554\end{array}$

REMARKS

Verified position of valves WTS-V-89, 90 , $91,92,93,95,96,98,99,302$, and 303. Valve 99 was in the open position. All other valves were in the closed position.

Verified the position of valves WTS-V-99 and 302 . Valve 99 was in the open position and valve 302 was in the closed position.

Verified the position of valve WTS-V-22. The valve was in the open position.

Verified the position of valve WTS-V-22. The valve was in the closed position.

Documented position of valve WTS-V-89 in the closed position.

The conductivity probe was deployed at the setpoint.

The conductivity probe was deployed at the setpoint.

The conductivity probe was deployed at the setpoint.

The conductivity probe was deployed at the setpoint.

The conductivity probe was deployed at the setpoint.

Verifled the conductivity probe was positioned on the MLDB floor.

Verified the conductivity probe was positioned on the MLDB floor.

The conductivity probe was deployed at the setpoint.

Verifled the conductlvity probe was positioned on the MLDB floor.

Documented the condition of the interior of the MLDB. No unusual conditions were observed.

Helium tracer test was performed on MLDB-02 at FDB-02. The test revealed a leaksite at MLDB-02.

The conductivity probe was deployed at the setpoint. 


\section{TANK OR ACCESS OPENING}

$\frac{\text { AREA }}{F} \frac{\text { ANCILLARY }}{\text { DB-02 }} \frac{\frac{\text { (A OR I) }}{\text { MLDB-03 }}}{\text { DATE }} \frac{\text { METHOD }}{\text { CCTV }} \frac{\text { FILE I.D.\# }}{\text { NA }}$

$\mathbf{F}$

DB-02

MLDB-03

06/16/99

HELIUM

HE-99-010

$\mathbf{F}$

DB-02

MLDB-03

12/16/99

CCTV

554

$\mathbf{F}$

DB-02

MLDB-04

03/17/99

CCTV

554

F

DB-02

MLDB-05

01/20/99

CCTV

554

F

DB-02

MLDB-05

$03 / 11 / 99$

CCTV

554

F

DB-02

MLDB-05

03/17/99

CCTV

554

$\mathbf{F}$

DB-02 MLDB-05

$04 / 12 / 99$

CCTV

554

F

DB-02

MLDB-05

$04 / 21 / 99$

CCTV

554

F

DB-02 MLDB-05

05/08/99

CCTV

554

$\mathbf{F}$

DB-02 MLDB-06

$01 / 20 / 99$

CCT

554

$\mathbf{F}$

DB-02

MLDB-08

01/06/99

CCTV

554

$\mathbf{F}$

DB-02

MLDB-08

$01 / 11 / 99$

CCTV

554

$\mathbf{F}$

DB-02 MLDB-08

05/24/99

CCTV $\quad 554$

\section{REMARKS}

Inspection revealed water was encountered approximately 11 1/2 feet into the standpipe. Water was $71 / 2$ feet deep in the containment.

Inspection revealed liquid and mud on the bottom of the MLDB up to the standpipe.

Helium tracer test was performed on MLDB-03 at FDB-02. The test revealed a leaksite at MLDB-03.

The conductivity probe was deployed at the setpoint.

The conductivity probe was deployed at the setpoint.

Documented position of the conductivity probe. The probe was not vislble due to water in the MLDB.

Inspection revealed the conductivity probe standpipe was submerged in liquid. No probe was visible.

Inspection revealed that the probe placement could not be determined. Access to the interior of the MLDB was blocked by what appeared to be plastic tubing.

Inspection revealed the conductivity probe location could not be determined because of an abandoned hose and water obstructing view in the MLDE.

Inspection revealed the conductivity probe was deployed at the setpoint.

Inspection revealed the conductivity probe was deployed at the setpoint.

Verified the conductivity probe was positioned on the MLDB floor.

Determined the conductivity probe was not positioned at setpoint due to the debris directly underneath the standpipe.

The conductivity probe was deployed at the setpoint.

The conductivity probe was deployed at the setpoint. 


\section{TANK OR ACCESS OPENING}

\begin{tabular}{|c|c|c|c|c|c|}
\hline AREA & ANCILLARY & (A OR I) & DATE & METHOD & FILE I.D. \# \\
\hline $\mathbf{F}$ & DB-02 & MLDB-09 & $01 / 13 / 99$ & CCTV & 554 \\
\hline H & DB-02 & & $01 / 11 / 99$ & CCTV & 555 \\
\hline$H$ & DB-02 & & $02 / 16 / 99$ & CCTV & 555 \\
\hline H & DB-02 & & 03/11/99 & CCTV & 555 \\
\hline H & DB-02 & & 09/26/99 & CCTV & \\
\hline H & DB-02 & LDB-01 & 01/29/99 & CCTV & 554 \\
\hline H & DB-02 & MLDB-04 & 01/28/99 & CCTV & 554 \\
\hline$H$ & DB-02 & MLDB-05 & $01 / 22 / 99$ & CCTV & 554 \\
\hline H & DB-02 & MLDB-06 & $01 / 22 / 99$ & CCTV & 554 \\
\hline H & DB-02 & MLDB-06 & $04 / 15 / 99$ & CCTV & 554 \\
\hline$F$ & DB-03 & & $08 / 17 / 99$ & CCTV & 555 \\
\hline $\mathbf{F}$ & DB-03 & MLDB-01 & $01 / 25 / 99$ & CCTV & 554 \\
\hline $\mathbf{F}$ & DB-03 & MLDB-01 & $01 / 27 / 99$ & CCTV & 554 \\
\hline $\mathbf{F}$ & DB-03 & MLDB-01 & 0.4/29/99 & CCTV & 554 \\
\hline$F$ & DB-03 & MLDB-02 & $04 / 06 / 99$ & CCTV & 554 \\
\hline$F$ & DB-03 & MLDB-02 & 04/07/99 & CCTV & 554 \\
\hline $\mathbf{F}$ & DB-03 & MLDB-02 & 04/08/99 & CCTV & 554 \\
\hline
\end{tabular}

\author{
REMARKS \\ Verified the conductivity probe was \\ positioned on the MLDB floor. \\ Verified the position of valves WTS-V-136, \\ 142 , and 146. The valves were in the \\ closed position.
}

Verified the position of valves WTS-V-142 and 146. The valves were in the closed position.

Verifled the position of valve WTS-V-142. The valve was in the closed position.

Verified position of valves WTS-V-128, 133 , $134,136,140,141,142,145,146$, and 147. The valves were in the closed position.

The conductivity probe was deployed at the setpoint.

The conductivity probe was deployed at the setpoint.

The conductivity probe was deployed at the setpoint.

The conductivity probe was deployed at the setpoint.

The conductivity probe was deployed at the setpoint.

Verifled the position of valves WTS-V-151 and 153. Valve 151 was in the closed position and valve 153 was in the open position.

Verifled position of the conductivity probe. The probe was positioned on the MLDB floor.

The conductivity probe was deployed at the setpoint.

The conductivity probe was deployed at the setpoint.

Inspection revealed the conductivity probe was resting in mud.

Inspection revealed after flushing the conductivity probe was positioned on the MLDB floor.

The conductivity probe was deployed at the setpoint. 


\begin{tabular}{|c|c|c|c|c|c|}
\hline AREA & $\begin{array}{c}\text { TANK OR } \\
\text { ANCILLARY } \\
\end{array}$ & $\frac{\text { ACCESS OPENING }}{(\text { A OR I) }}$ & DATE & METHOD & FILE I.D.\# \\
\hline $\mathbf{F}$ & DB-03 & MLDB-02 & $04 / 29 / 99$ & CCTV & 554 \\
\hline $\mathbf{F}$ & DB-04 & & 08/19/99 & CCTV & 555 \\
\hline $\mathbf{F}$ & DB-04 & & 08/29/99 & CCTV & 555 \\
\hline $\mathbf{F}$ & DB-04 & & $08 / 31 / 99$ & CCTV & 555 \\
\hline $\mathbf{F}$ & DB-04 & & $10 / 07 / 99$ & cctV & NA \\
\hline $\mathbf{F}$ & DB-04 & & $11 / 05 / 99$ & CCTV & 555 \\
\hline $\mathbf{F}$ & DB-04 & & $11 / 11 / 99$ & CCTV & 555 \\
\hline $\mathbf{F}$ & DB-04 & & 12/28/99 & CCTV & 555 \\
\hline $\mathbf{F}$ & DB-04 & LDB-01 & 05/07/99 & cCTV & 559 \\
\hline $\mathbf{F}$ & DB-04 & LDB-01 & 05/09/99 & CCTV & 554 \\
\hline$F$ & DB-04 & LDB-01 & $05 / 16 / 99$ & CCTV & 554 \\
\hline $\mathbf{F}$ & DB-04 & LDB-02 & $01 / 07 / 99$ & CCTV & 554 \\
\hline$F$ & DB-04 & LDB-02 & $05 / 08 / 99$ & CCTV & 554 \\
\hline$F$ & DB-04 & LDB-02 & $06 / 22 / 99$ & CCTV & NA \\
\hline $\mathbf{F}$ & DB-04 & LDB-02 & $06 / 24 / 99$ & CCTV & 554 \\
\hline$r$ & DB-04 & LDB-03 & $03 / 25 / 99$ & CCTV & 554 \\
\hline
\end{tabular}

\author{
REMARKS \\ The conductivity probe was deployed at \\ the setpoint. \\ Verified the position of valves WTS-V-224, \\ 226 and 229. The valves were in the closed \\ position.
}

Verified the position of valve WTS-V-224.

The valve was in the closed position.

Verifled the position of valve WTS-V-224. The valve was in the closed position.

Verifled the position of valve WTS-V-224. The valve was in the closed position.

Verifled position of valve WTS-V-224. The valve was in the closed position.

Verified position of valve WTS-V-224. The valve was in the closed position.

Verified position of valve WTS-V-224. The valve was in the closed position.

Documented an attempt made to chase the threads in the drain utilizing a tap. The attempt was unsuccessful because the drain plug did not line up properly with the drain guide pipe. After several attempts, the plug was successfully installed in the drain allowing a pressure test to be performed.

The conductivity probe was deployed at the setpoint.

Assisted with positioning the conductlvity probe in the LDB. The probe was deployed at the setpoint.

Inspection determined the conductivity probe was not visible.

Documented position of the conductivity probe. The probe was not visible.

Inspection revealed that the LDB was successfully flushed.

The conductivity probe was deployed at the setpoint.

The conductivity probe was deployed at the setpoint. 
TANK OR ACCESS OPENING

\begin{tabular}{|c|c|c|c|c|c|}
\hline AREA & ANCILLARY & (A OR I) & DATE & METHOD & FILE I.D. \# \\
\hline$F$ & DB-04 & LDB-04 & $01 / 07 / 99$ & CCTV & 554 \\
\hline$F$ & DB-04 & LDB-04 & $01 / 26 / 99$ & CCTV & NA \\
\hline $\mathbf{F}$ & DB-04 & LDB-04 & $01 / 28 / 99$ & CCTV & 554 \\
\hline $\mathbf{F}$ & DB-04 & LDB-05 & 03/29/99 & CCTV & 554 \\
\hline $\boldsymbol{F}$ & DB-04 & LDB-06 & $05 / 20 / 99$ & CCTV & 554 \\
\hline$F$ & DB-04 & LDB-07 & $06 / 17 / 99$ & CCTV & NA \\
\hline $\mathbf{F}$ & DB-04 & LDB-07 & $06 / 24 / 99$ & CCTV & 554 \\
\hline$F$ & DB-04 & LDB-08 & $04 / 21 / 99$ & cctV & 554 \\
\hline $\mathbf{F}$ & DB-04 & LDB-10 & $01 / 26 / 99$ & CCTV & NA \\
\hline $\mathbf{F}$ & DB-04 & LDB-10 & $06 / 21 / 99$ & cctV & NA \\
\hline$F$ & DB-04 & LDB-10 & $06 / 22 / 99$ & CCTV & 554 \\
\hline $\mathbf{F}$ & DB-04 & LDB-12 & $06 / 17 / 99$ & CCTV & 554 \\
\hline $\mathbf{F}$ & DB-04 & LDB-13 & $01 / 26 / 99$ & CCTV & NA \\
\hline $\mathbf{F}$ & DB-04 & LDB-13 & $03 / 11 / 99$ & CCTV & 554 \\
\hline $\mathbf{F}$ & DB-04 & LDB-14 & $05 / 08 / 99$ & CCTV & 554 \\
\hline$F$ & DB-04 & LDB-15 & $01 / 26 / 99$ & CcTV & 554 \\
\hline H & DB-04 & & 08/09/99 & CCTV & 559 \\
\hline H & DB-05 & & $02 / 22 / 99$ & CCTV & 555 \\
\hline
\end{tabular}

\begin{abstract}
REMARKS
Inspection determined an obstruction was in the conductivity probe standpipe. The probe was not deployed.

Inspectlon determined the conductivity probe was not visible.

The conductivity probe was deployed at the setpoint.

The conductivity probe was deployed at the setpoint.

The conductivity probe was deployed at the setpoint. Debris was observed beneath the probe.
\end{abstract}

Inspection revealed that the LDB was successfully flushed.

The conductivity probe was deployed at the setpoint.

The conductivity probe was deployed at the setpoint.

Inspection determined the conductivity probe was not visible.

Inspection revealed that the LDB was successfully flushed.

The conductivity probe was deployed at the setpoint.

The conductivity probe was deployed at the setpoint.

Inspection determined the conductivity probe was not visible. The MLDB contained water.

The conductivity probe was deployed at the setpoint.

The conductivity probe was deployed at the setpoint.

\footnotetext{
Verifled the conductivity probe was positioned on the MLDB floor.

Determined that water was in the sump.

Verifled the position of valves WTS-V-105, $106,107,108$, and 109. The valves were in the closed position.
} 


\begin{tabular}{|c|c|c|c|c|c|}
\hline AREA & $\begin{array}{c}\text { TANK OR } \\
\text { ANCILLARY }\end{array}$ & $\frac{\text { ACCESS OPENING }}{(A \text { OR I) }}$ & DATE & METHOD & FILE I.D. \# \\
\hline H & DB-05 & & $05 / 10 / 99$ & CCTV & 555 \\
\hline $\mathrm{H}$ & DB-05 & & $05 / 12 / 99$ & CCTV & 555 \\
\hline$H$ & DB-05 & & $07 / 22 / 99$ & CCTV & 555 \\
\hline$H$ & DB-05 & & $11 / 06 / 99$ & CCTV & 555 \\
\hline $\mathbf{F}$ & DB-06 & LDB-01 & $01 / 12 / 99$ & CCTV & 554 \\
\hline $\mathbf{F}$ & DB-06 & $\begin{array}{l}\text { Underliner } \\
\text { Sump }\end{array}$ & $11 / 10 / 99$ & CCTV & NA \\
\hline$H$ & DB-06 & & 06/29/99 & CCTV & 555 \\
\hline H & DB-06 & & 07/01/99 & CCTV & 555 \\
\hline $\mathbf{H}$ & DB-06 & & 07/07/99 & CCTV & 555 \\
\hline H & DB-06 & & 07/22/99 & cctV & 555 \\
\hline H & DB-06 & & $08 / 04 / 99$ & CCTV & 559 \\
\hline H & DB-06 & & $08 / 12 / 99$ & CCTV & 555 \\
\hline H & DB-06 & & $11 / 12 / 99$ & CCTV & 555 \\
\hline H & DB-06 & & $11 / 22 / 99$ & CCTV & 555 \\
\hline H & DB-06 & & 12/30/99 & CCTV & 555 \\
\hline H & DB-06 & LDB-01 & 02/25/99 & CCTV & 554 \\
\hline H & DB-06 & LDB-02 & $02 / 25 / 99$ & CCTV & 554 \\
\hline
\end{tabular}

\section{REMARKS}

Verified the position of valves WTS-V-105, 560, and 563. Valves 105 and 563 were in the closed position. Valve $\mathbf{5 6 0}$ was in the open position.

Verifled the position of valve WTS-V-105. The valve was in the closed position.

Verifled the position of valve WTS-V-108. The valve was in the closed position.

Verifled position of valve WTS-V-107. The valve was in the closed position.

Determined that the conductivity probe was positioned on the LDB floor.

Documented conditions in the underliner sump. Sand, silt, mud, and water were observed in the bottom of the standpipe. The conductivity probe could not be observed.

Verified the position of valve WTS-V-56. The valve was in the closed position.

Verified the position of valve WTS-V-56. The valve was in the closed position.

Verified the position of valve WTS-V-56. The valve was in the closed position.

Verifled the position of valve WTS-V-56. The valve was in the closed position.

Inspection revealed no extraneous material was present which would prevent the conductivity probe from being properly installed in the sump area.

Verified the position of valve WTS-V-56. The valve was in the closed position.

Verified position of valve WTS-V-56. The valve was in the closed position.

Verified position of valve WTS-V-56. The valve was in the closed position.

Documented position of valve WTS-V-56. The valve was in the closed position.

The conductivity probe was deployed at the setpoint.

The conductivity probe was deployed at the setpoint. 
TANK OR ACCESS OPENING

AREA ANCILLARY$$
\text { H }
$$$$
\text { DB-06 }
$$

(A OR I)

DATE

DATE

$\frac{\text { METHOD }}{\text { CCTV }} \quad$ FILE I.D. \#

H

DB-06

LDB-04

02/25/99

CCTV

554

H

DB-06 LDB-05

$02 / 25 / 99$

CCTV

554

H

DB-07

H

DB-07

H

H

H

H

H

DB-07

H

DB-07

H

DB-07

H

DB-07

H

DB-07

H

DB-07

H

DB-07

$07 / 17 / 99$

CCTV

\section{REMARKS}

The conductivity probe was deployed at the setpoint.

The conductivity probe was deployed at the setpoint.

The conductivity probe was deployed at the setpoint.

Verified the position of valves WTS-V-56, 58,157 , and 158 . The valves were in the closed position.

Verified the position of valve WTS-V-163. The valve was in the closed position.

Verified the position of valves WTS-V-157, 158 and 159 . The valves were in the closed position.

Verified the position of valves WTS-V-157 and 158. The valves were in the closed position.

Verifled the position of valve WTS-V-163. The valve was in the closed position.

Verified the position of valve WTS-V-163. The valve was in the closed position.

Verifled the position of valves WTS-V-159, 160,161 , and 162 . The valves were in the closed position.

Verifled the position of valve WTS-V-61. The valve was in the closed position.

Verified the position of valve WTS-V-62. The valve was in the closed position.

Verifled the position of valves WTS-V- 156 and 157. Valves 156 and 157 were in the closed position.

Verified the position of valve WTS-V-57. The valve stops did not completely come to rest on the pins. The valve was not fully closed.

Verified the position of valves WTS-V-52 and 53. The valves were in the closed position.

Verifled the position of valve WTS-V-163. The valve was not fully closed. 
TANK OR ACCESS OPENING

$\frac{\text { AREA }}{\mathrm{H}} \frac{\text { ANCILLARY }}{\mathrm{DB}-07} \frac{(\mathrm{A} \text { OR I })}{07 / 21 / 99} \frac{\text { DATE }}{\text { CCTV }} \underset{555}{\text { METHOD }}$

H

DB-07

DB-07

DB-07

H

DB-07

H

DB-07

H

DB-07

H

DB-07

H

DB-07

H

$$
\text { DE-07 }
$$

H

$$
\text { DB-07 }
$$

H

DB-07
08/01/99

CCTV

555

08/19/99

CCTV

NA

$09 / 03 / 99$

09/08/99

CCTV

555

09/10/99

CCTV

555

CCTV

555

09/13/99

CCTV

555

09/14/99

CCTV

555

$09 / 23 / 99$

CCTV

619

10/01/99
CCTV $\quad 555$

\section{REMARKS}

Verified the position of valve WTS-V-163. The valve was in the closed position. A slight gap between the valve stop and pins was observed. However, the stops on the valve stem were completely closed.

Verified the position of valves WTS-V-62 and 163. The valves were in the closed position.

Verified the position of valves WTS-V-63 and 163. The valves were in the closed position.

Verifled the position of valves WTS-V-159, 160 and 161. The valves were in the closed position.

Verified the position of valve WTS-V-163. The valve was in the closed position.

Verifled the position of valves WTS-V-62 and 163. The valves were in the closed position.

Verified position of valves WTS-V- 62 and 163. The valves were placed in the open position. After vent/drain, valve 62 was placed in the closed position.

Verified position of valves WTS-V-62 and 163. The valves were in the closed position.

Verifled position of valves WTS-V-62 and 163. The valves were in the open position.

Verified position of valves WTS-V-62 and 163. The valves were in the open position.

Assisted with a leak check of jumper 13(HDB7)5F. A leak was observed at the 5F connector head.

Verified the positlon of valves WTS-V-57, $59,60,63,156$ and 162 . Valves 60,63 and 162 were in the closed position. Valve 57 was open halfway at bottom stop; top stop was closed. Valve 59 was open quarter-way at bottom stop; top stop was spinning. Valve 156 was not fully closed at the bottom stop; however, the top stop was closed. 
TANK OR ACCESS OPENING

$\frac{\text { AREA }}{H} \frac{\text { ANCILLARY }}{\text { DB-07 }} \frac{\frac{\text { (A OR I) }}{10 / 01 / 99}}{\text { CCTV }} \frac{\text { DATE }}{555}$

H

DB-07

H

DB-07

H

H

H

H

H

H

DB-07

H

DB-07

H

DB-07

H

DB-07

H

DB-07

$10 / 02 / 99$

CCTV

555

10/02/99

CCTV

555

10/07/99

CCTV

555

DB-07

DB-07

DB-07

DB-07

$10 / 17 / 99$

CCTV

555

10/07/99

CCTV

555

10/13/99

CCTV

619

CCTV

555

$10 / 16 / 99$

(1)
Veriffed the position of valves WTS-V-52, $53,62,159,160,161$, and 163 . The valves were in the closed position. Valve 53 had salt on the valve body, valve 161 was found in the open position, and valves 52 and 163 were closed.

Assisted with performing a leak check of jumper 13(HDB7)5F after regasketing. A leak was observed at $5 \mathrm{~F}$ connector head. Valves 62 and 163 were in the closed position.

Verified position of valves WTS-V- 62 and 163. The valves were in the closed position.

Assisted with leak check of jumper 13(HDB7)5F. A leak was observed at the $5 \mathrm{~F}$ connector head.

Verified position of valves WTS-V-62 and 163. The valves were in the open position.

Assisted with cleaning and regasketing nozzles for jumper 13(HBD7)5F and to perform a leak check. The jumper was leak tree.

Verified the position of valves WTS-V-52, $53,57,59,60,61,62,63,156,162$ and 163 . The valves were in the closed position. Valves 59 and 62 showed some shaft/valve slipping.

Verifled the position of valves WTS-V-62 and 163. The valves were in the closed position.

Verified the position of valves WTS-V-62 and 163 . The valves were in the closed position.

Verifjed the position of valves WTS-V-159, 160 and 161 . The valves were in the closed position.

Verified position of valves WTS-V-62 and 163. The valves were in the closed position.

Verified position of valves WTS-V- 62 and 163. Valve 62 was in the closed position and valve 163 was almost closed.

Documented the position of valve WTS-V-158. The valve was in the closed position. 
TANK OR ACCESS OPENING

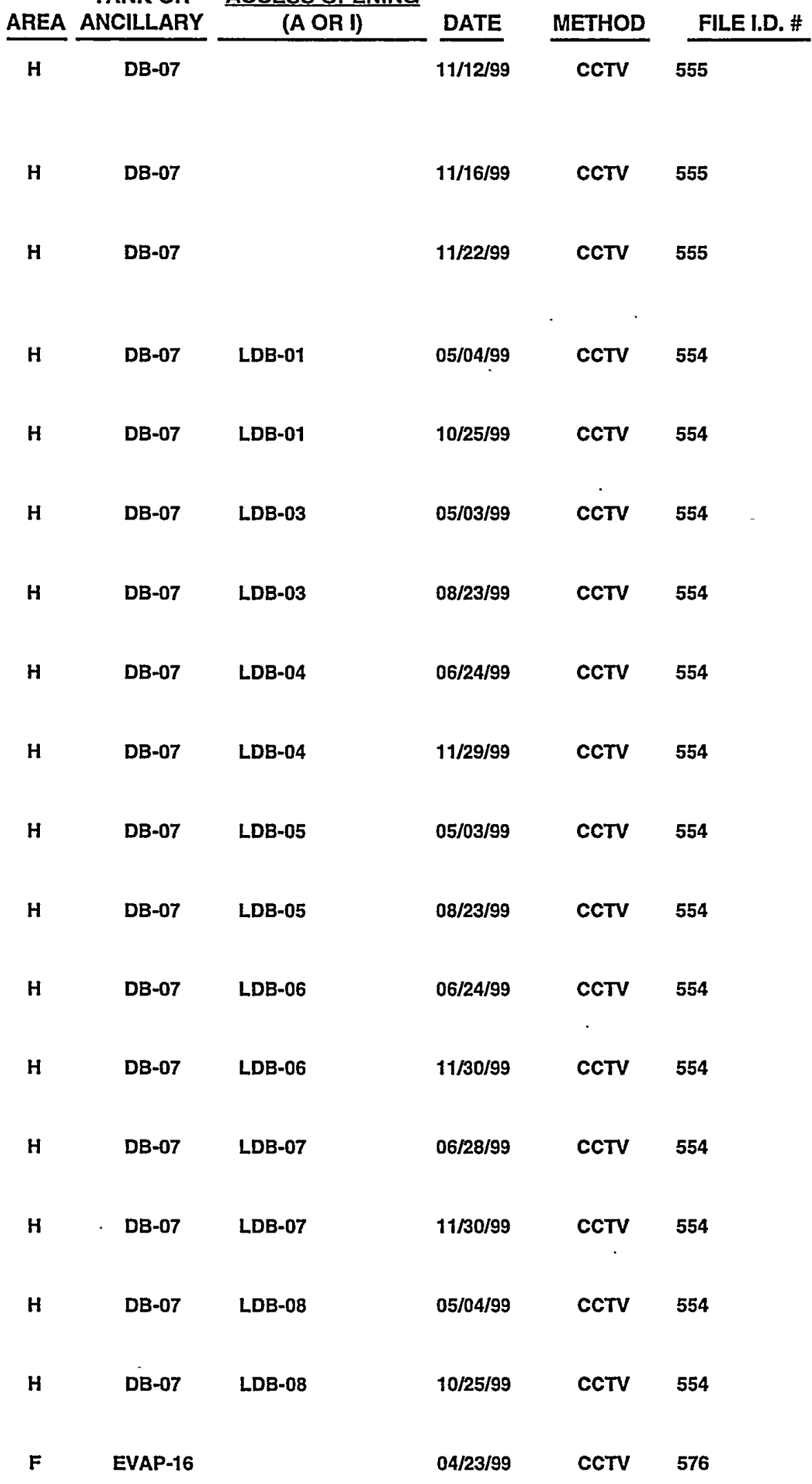

\section{REMARKS}

Verified position of valves WTS-V-157, 158, and 159. The valves were in the closed position.

Verified the position of valve WTS-V-58. The valve was in the closed position.

Verified the position of valves WTS-V-62, $157,158,159,160,161$ and 165 . The valves were in the closed position.

The conductivity probe was deployed at the setpoint.

The conductivity probe was deployed at the setpoint.

The conductivity probe was deployed at the setpoint.

The conductivity probe was deployed at the setpoint.

The conductivity probe was deployed at the setpoint.

The conductivity probe was deployed at the setpoint.

The conductivity probe was deployed at the setpoint.

The conductlvity probe was deployed at the setpoint.

The conductivity probe was deployed at the setpoint.

The conductivity probe was deployed at the setpoint.

The conductivity probe was deployed at the setpoint.

The conductivity probe was deployed at the setpoint.

The conductivity probe was deployed at the setpoint.

The conductivity probe was deployed at the setpoint.

Inspection in the cell revealed that conditions were normal. No evidence of leaks was found. 


\section{TANK OR ACCESS OPENING}

$\frac{\text { AREA ANCILLARY }}{F} \frac{\frac{\text { A OR I) }}{\text { EVAP-16 }}}{\frac{\text { DATE }}{10 / 28 / 99}} \frac{\text { METHOD }}{\text { CCTV }} \underset{630}{\text { FILE I.D. \# }}$

$\mathbf{F}$

EVAP-16

SE

$12 / 15 / 99$

CCTV

630

$\mathbf{F}$

$$
\text { EVAP-16 }
$$

SE

$12 / 31 / 99$

CCTV

559

H

EVAP-16

H

EVAP-16

H

EVAP-16

E-04

$10 / 31 / 99$

CCTV

627

H

EVAP-16

SW

$11 / 02 / 99$

CCTV

628

H

EVAP-16

SW

$11 / 10 / 99$

CCTV

CCTV

\section{REMARKS}

Inspection of the evaporator cell revealed no unusual conditions. A small amount of what appeared to be mercury was observed on the floor in the NE corner. The $(N)$ instrument jumper was removed and regasketed. The jumper was replaced and leak tested. On the first attempt, the jumper leaked. Wall nozzle 4 was tightened additionally and on the subsequent leak test the jumper was leak free.

Assisted with leak check of jumpers after an increase in the sump was detected. The " $N$ " instrument jumper connector was leaking steam at the nozzle.

Inspection revealed that the instrument jumper connector head was not properly seated. The connector head was reseated and tightened. The leak check was deferred and scheduled as a pre startup activity.

Inspected the evaporator cell and leak check WTS-V-262. No leaks were observed.

Verified the position of valves WEE-V-236 and 255 and documented leak check. No leaks were observed.

Assisted with remote sampling of the evaporator pot. Inspection revealed solids on the vessel wall, tube bundle, heating coils, and other exposed surfaces. A sample of solids was collected from the bottom of the vessel.

Inspection of the evaporator pot and cell showed no signs of degradation. An accumulation of salt was observed on the vent jumper at the top of the west separator pot which indicated that the gasket had failed. A plastic bag was observed in the sump. Extraneous Items were observed on the floor.

Assisted with performing leak check after the gasket was replaced on the vent jumper. No leakage was observed.

Inspection revealed that the rubber O-ring around the demister did not make a complete seal against the evaporator vessel.

The conductivity probe for ETF overhead line was deployed at the setpoint. 
TANK OR ACCESS OPENING AREA ANCILLARY

H EVAP-25 (A OR I)

DATE

GDL Cell

$11 / 28 / 99$

METHOD

CCTV

FILE I.D. \# 639

\begin{tabular}{|c|c|c|c|c|}
\hline H & EVAP-25 & LDB-105 & $11 / 01 / 99$ & CCTV \\
\hline H & EVAP-25 & LDB-105 & $11 / 23 / 99$ & CCTV \\
\hline H & EVAP-25 & LDB-112 & $09 / 23 / 99$ & CCTV \\
\hline H & EVAP-25 & LDB-122 & $11 / 01 / 99$ & CCTV \\
\hline H & EVAP-25 & LDB-122 & $11 / 04 / 99$ & CCTV \\
\hline H & EVAP-25 & & $03 / 31 / 99$ & CCTV \\
\hline
\end{tabular}

H EVAP-25 NE

H

EVAP-25

NE

$10 / 04 / 99$

CCTV

621

H EVAP-25 NE

$11 / 28 / 99$

CCTV

639

H

EVAP-25 NE

$12 / 28 / 99$

CCTV

639

H

EVAP-25 NW

$11 / 28 / 99$

CCTV

639

H

EVAP-25 SE
$11 / 28 / 99$
cCTV

\section{REMARKS}

Inspection of GDL cell area revealed surface corrosion along the welds on top of the pipes. The ceiling and walls were satisfactory. The floor area contained extraneous items such as a broom, a fire extinguisher, a plastic bag, a light stand and tools.

Inspection revealed water in the standpipe.

Documented that the conductivity probe was positioned on the LDB floor.

The conductivity probe was deployed at the setpoint.

The conductivity probe was deployed at the setpoint.

Determined the length of the standpipe. The measured length was 254 inches.

Performed a baseline inspection of the 242-25H evaporator cell after operation with simulated waste. Inspection revealed a residue of simulated waste at a lift jumper connector.

Performed a basellne inspection. Dry leaked simulated waste was observed on the cell floor and on the exterior wall of the evaporator pot.

Documented conditions in sump and cell area. An accumulation of deposits on nozzle U-2 indicate that the gasket had tailed.

Inspection of the evaporator cell area revealed stains and deposits on the floor, the lift jumper nozzle plate, and the pot insulation.

Documented conditions in the evaporator cell and of the pot exterior. No changes were observed since last inspected on 11/28/99.

Inspection of the evaporator cell area revealed stains and deposits on the floor, the lift jumper nozzle plate, and the pot insulation.

Inspection of the evaporator cell area revealed stains and deposits on the floor, the lift jumper nozzle plate, and the pot insulation. 


\section{TANK OR ACCESS OPENING}

\begin{tabular}{|c|c|c|c|c|c|}
\hline AREA & ANCILLARY & (A OR I) & DATE & METHOD & FILE I.D. \\
\hline$H$ & EVAP-25 & $\begin{array}{l}\text { Simulate } \\
\text { Tank }\end{array}$ & 06/29/99 & CCTV & 559 \\
\hline H & EVAP-25 & sw & 09/28/99 & CCTV & 621 \\
\hline H & EVAP-25 & sw & $10 / 06 / 99$ & cctv & 621 \\
\hline
\end{tabular}

H EVAP-25 SW EVAP-25 SW EVAP-25 SW

IAL High Point

02/10/99

CCTV 555

IAL High Point

11/03/99

CCTV

IAL High Point

$11 / 11 / 99$

$\operatorname{ccTV}$

555

IAL High Point

$11 / 12 / 99$

CCTV

555

IAL High Polnt

$11 / 22 / 99$

\section{REMARKS}

Inspection revealed no accumulation of material on underside of dome that would prevent relief valve from operating properly. No other unusual conditions were observed.

Inspection of the condition in the sump area and cell area revealed liquid about one foot deep in the cell.

Inspection revealed an accumulation of dried waste simulant on the cell floor. The accumulation height was approximately 8 to 10 inches sloping from the NE corner to the SW sump corner. The Jupiter Jumper, SS liner, evaporator pot and other associated piping was coated with the salt.

Inspection revealed accumulation of waste simulant on the floor and along the sump area. After the cleaning efforts the pot, walls, and nozzles appear to be free of simulant.

Inspection of the interior of the evaporator pot after simulated waste was processed revealed no unusual buildup on the walls, the demister, the tube bundles, or in the cone area were observed.

Inspection of the evaporator cell area revealed stains and deposits on the floor, the lift jumper nozzle plate, and the pot insulation.

Verified the position of valves IT-V-40, 41, $42,43,44,45,46$, and 47 . All the valves were in the closed position except for 43 . It was in the open position.

Verified position of valves IT-V-40, 41, 42, $43,44,45,46$, and 47 . The valves were in the closed position.

Verifled position of valves IT-V-41, 43,45 , and 46 . The valves were in the closed position.

Verified position of valves IT-V- $-41,43,45$, and 46. The valves were in the closed position.

Documented the position of valves IT-V-41, 43,45 and 46 . The valves were In the closed position. 


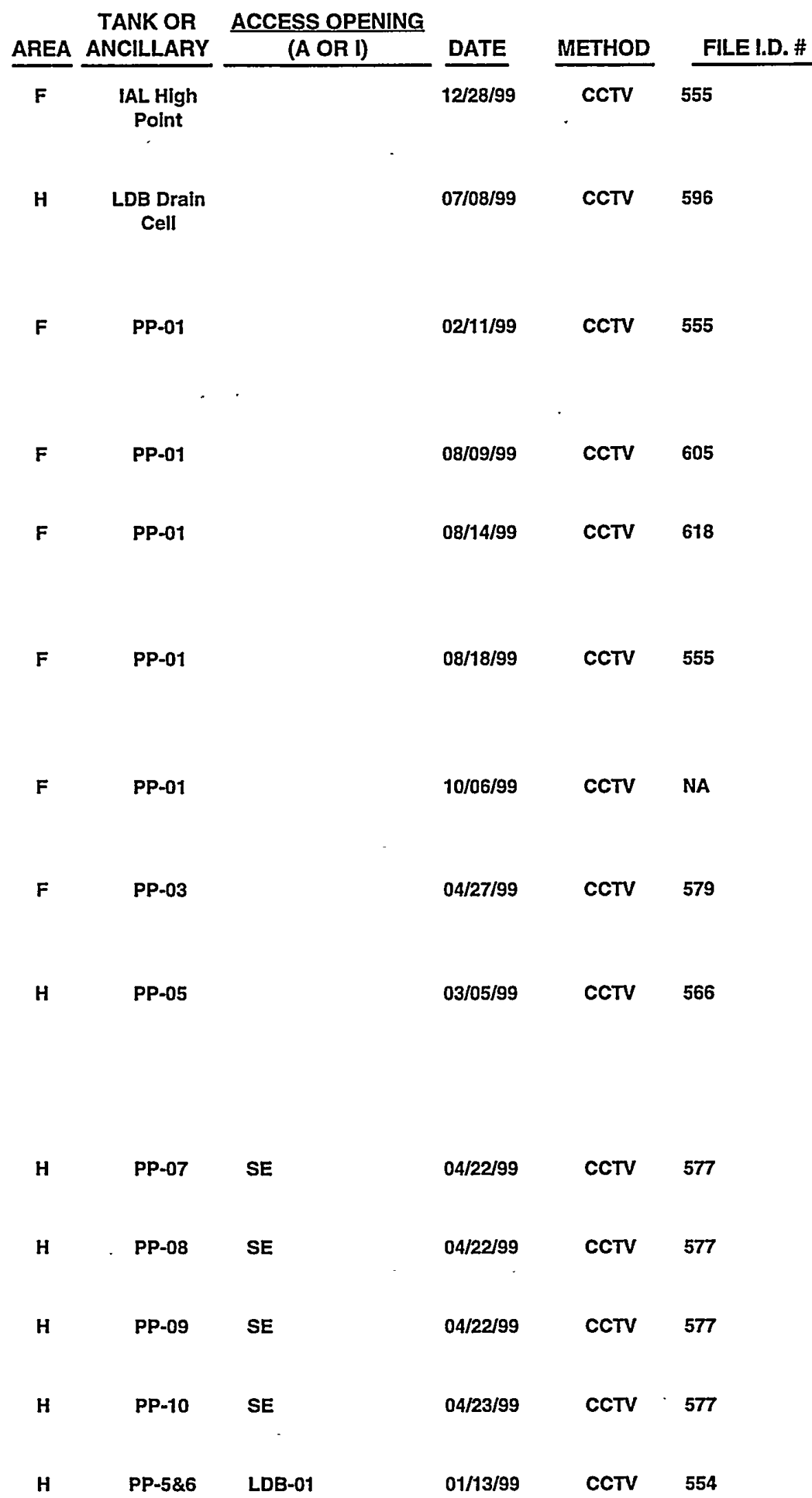

REMARKS

Documented position of valves IT-V-40, 41 , 45 , and 46 . The values were in the closed position.

The conductivity probe was properly positioned. A sample vial with string, a steel rod, mud, hose, and cable were observed on the floor or in the sump.

Verified the position of valves IT-V-1 and 2. Valve 1 was not manipulated and was found to be $85 \%$ open. Valve 2 was in the closed position.

Inspection of the sump pump wirlng revealed all wiring was Intact.

Provided video support to gulde installation of the sump pump and to document it pumped out the sump adequately to clear alarms.

Verifled position of valves WTS-V-1, 2, 100, 101,102 , and 226. Valve 1 was found to be positioned half open. All valves were left in the closed position.

Verified the position of valve IT-V-1. The valve was observed to be $3 / 4$ of the way open.

Documented conditions of the pump pit and the configuration of jumpers. No unusual conditions were observed.

Provided video to aid with remote sampling of the pump tank. An organic layer, dip, and variable depth (sludge) sample were obtained. Some solids and pleces of rubber gloves were observed on the surface of the llquid in the tank.

Verified that the pump tank overflow lines were free of obstructions.

Verified that the pump tank overflow lines were free of obstructions.

Verified that the pump tank overflow lines were free of obstructions.

Verifled that the pump tank overflow lines were free of obstructions.

The conductivity probe was deployed at the setpoint. 


\begin{tabular}{|c|c|c|c|c|c|}
\hline AREA & $\begin{array}{l}\text { TANK OR } \\
\text { ANCILLARY }\end{array}$ & $\frac{\text { ACCESS OPENING }}{(A \text { OR I) }}$ & DATE & METHOD & FILE I.D. \# \\
\hline H & PP-5\&6 & LDB-02 & $02 / 02 / 99$ & CCTV & 554 \\
\hline H & PP-5\&6 & LDB-05 & $01 / 12 / 99$ & cctv & 554 \\
\hline H & PP-5\&6 & LDB-05 & 06/23/99 & CCTV & 554 \\
\hline H & PP-5\&6 & LDB-05 & $11 / 23 / 99$ & CCTV & 554 \\
\hline H & PP-5\&6 & LDB-07 & $01 / 12 / 99$ & CCTV & 554 \\
\hline H & PP.5\&6 & LDB-07 & $06 / 22 / 99$ & cctv & 554 \\
\hline$H$ & PP-5\&6 & LDB-07 & $11 / 09 / 99$ & CCTV & 554 \\
\hline$H$ & PT-10 & & $08 / 04 / 99$ & CCTV & 604 \\
\hline H & PT-10 & & 08/19/99 & cCTV & 604 \\
\hline $\mathbf{F}$ & sws & $2 F=03$ & 08/30/99 & CCTV & 609 \\
\hline $\mathbf{F}$ & sws & 2F-09 & $08 / 11 / 99$ & cctV & 606 \\
\hline
\end{tabular}

\author{
REMARKS \\ The conductivity probe was deployed at \\ the setpoint. \\ The conductivity probe was deployed at \\ the setpoint.
}

The conductivity probe was deployed at the setpoint.

The conductivity probe was deployed at the setpoint.

The conductivity probe was deployed at the setpoint.

The conductivity probe was deployed at the setpoint.

The conductivity probe was deployed at the setpoint.

Used video to document the contents of the pump tank, to inspect for frit, and to check for obstruction at the pump tank overflow discharge and the ventilation opening. Some solids were observed on the bottom of the pump tank. No obstruction was observed.

Used video to assist with sampling for organic and checking for obstruction at the overflow discharge. The sampling was performed successfully. The overflow was clear of obstruction.

Documented condition of storm drain. Inspection revealed conditions had not changed since inspected on 11/25/97.

Documented conditions of the RCP south of 2F-09. Approximately $\mathbf{4 0}$ feet of this segment was clean. At 42 feet, an accumulation of rocks and debris was observed which prevented further inspection.

Documented conditions of the RCP east of 2F-09. Approximately 96 feet of the RCP was inspected and sand was observed in the entire line with deepest sand, three to four inches, accumulating at the outlet.

Documented conditions of the RCP west of 2F-09. Approximately 110 feet of this segment was inspected and the line appeared to be free of debris and sand. No unusual conditions were observed. 


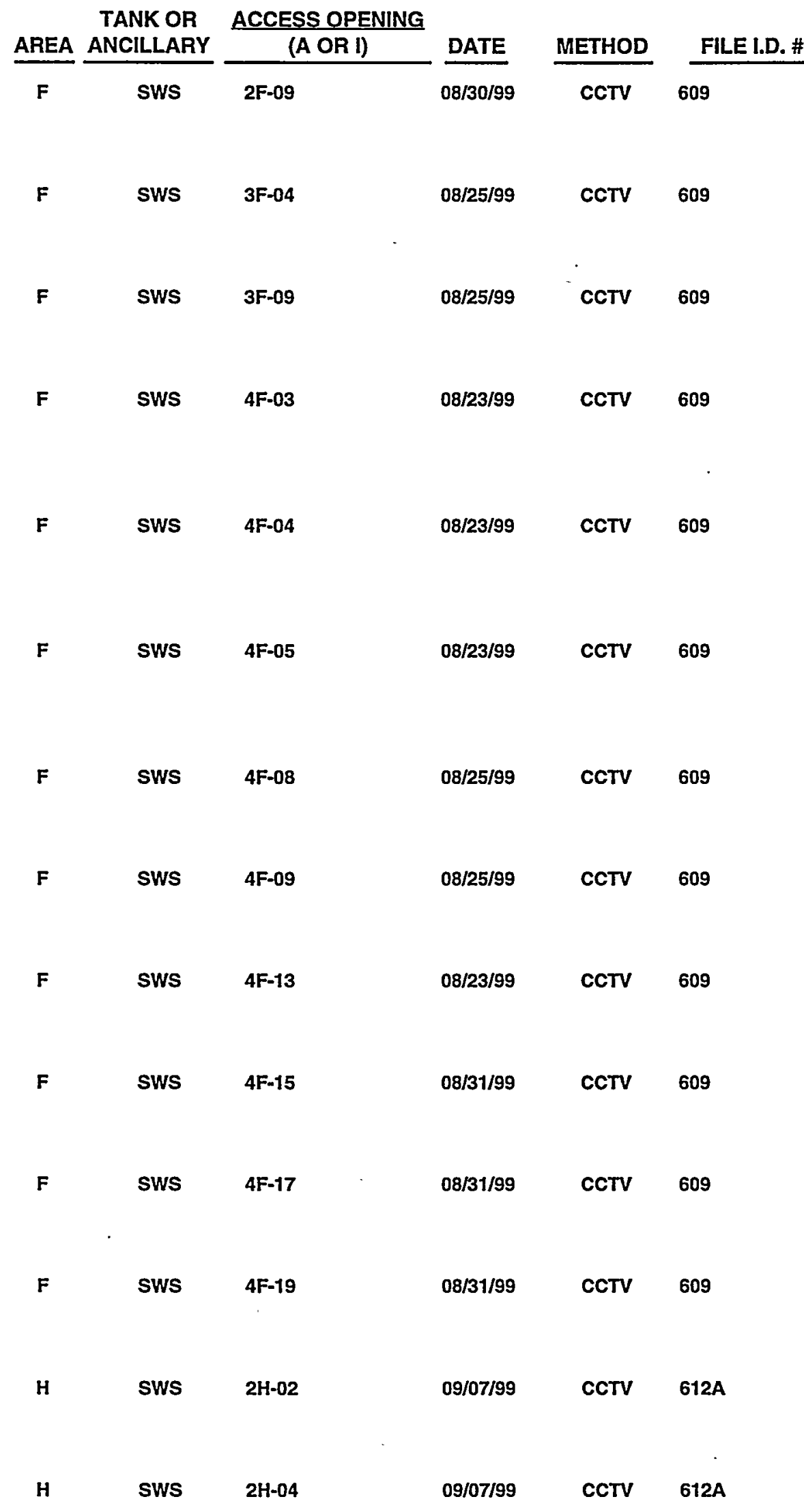

REMARKS

Documented condition of storm drain. Conditions had not changed since inspected on $06 / 26 / 97$.

Documented condition of storm drain. Conditions had not changed since inspected on 06/26/97.

Documented condition of storm drain. Conditions had not changed since inspected on $06 / 25 / 97$.

Documented condition of storm drain. Conditions had not changed since inspected on 06/24/97 except that water level appears to be higher.

Documented condition of storm drain. Conditions had not changed since inspected on 06/24/97 except that water level appears to be higher.

Documented condition of storm drain. Conditions had not changed since inspected on 06/24/97 except that water level appears to be higher.

Documented condition of storm drain. Conditions had not changed since inspected on 06/24/97.

Documented conditlon of storm drain. Conditions had not changed since inspected on $06 / 24 / 97$.

Documented condition of storm drain. Inspection revealed conditions had not changed since inspected on $08 / 5 / 98$.

Documented condition of storm drain. Conditions had not changed since inspected on $06 / 24 / 97$.

Documented condition of storm drain. Conditions had not changed since Inspected on 06/25/97.

Documented condition of storm drain. Conditions had not changed since inspected on 11/25/97.

Documented condition of the storm sewer. Conditions had not changed since Inspected on 11/25/97.

Documented conditions of the storm sewer. Conditions had not changed since inspected on 7/14/97. 
TANK OR ACCESS OPENING

\begin{tabular}{|c|c|c|c|c|c|}
\hline AREA & ANCILLARY & (A OR I) & DATE & METHOD & FILE I.D. \# \\
\hline $\mathrm{H}$ & SWS & $2 \mathrm{H}-06$ & 199 & CCTV & $612 B$ \\
\hline
\end{tabular}

H

SWS $\quad 2 \mathrm{H}-08$

09/07/99

CCTV

612A

H

H

H

H

SWS

$6 \mathrm{H}-08$

09/08/99

CCTV

612

H

SWS $\quad 6 \mathrm{H}-09$

$09 / 08 / 99$

CCTV

612

H

sws $\quad 7 \mathrm{H}-01$

$09 / 16 / 99$

CCTV

612

H

SWS $\quad 7 \mathrm{H}-02$
09/16/99

\section{REMARKS}

Documented the condition and establish a baseline for future inspections. Some sediment ( $1 / 4^{\prime \prime}$ to $1 / 2$ " deep) was observed in the inlet pipes and in one of the outlet pipes. Some rocks were observed on the bottom of the storm sewer. Some minor erosion was observed between some of the bricks and around the pipes. No evidence of structural fallure or significant Infiltration was observed.

Documented the condition of the storm sewer. Conditions had not changed since Inspected on 11/25/97.

Documented the condition of the storm sewer. Minor erosion of mortar between the bricks was noted. Also, a crack was observed on the concrete floor on the bottom of the sewer. No evidence of significant structural fallure or significant infiltration was observed.

Documented the condition of the storm sewer. Conditions had not changed since inspected on 10/15/97.

Documented the condition of the storm sewer. Conditions had not changed since inspected on $07 / 07 / 97$.

Documented the condition inside the storm sewer. Conditions had not changed since inspected on $07 / 15 / 97$.

Documented the condition inside the storm sewer. Minor erosion of the mortar between the bricks was observed. A crack was observed in the concrete liner of the storm sewer. No evidence of structural failure or significant infiltratlon was observed.

Documented the condition inside the storm sewer. Conditions had not changed since inspected on $07 / 15 / 97$.

Documented the condition Inside the storm sewer. A crack in the concrete was observed on the sIde wall. No further significant damage was observed since last inspection.

Documented the condition inside the storm sewer. Conditions had not changed since inspected on 10/15/97. 


\begin{tabular}{|c|c|c|c|c|c|}
\hline AREA & $\begin{array}{l}\text { TANK OR } \\
\text { ANCILLARY }\end{array}$ & $\frac{\text { ACCESS OPENING }}{(\text { A OR I) }}$ & DATE & METHOD & FILE I.D. \# \\
\hline$F$ & WLE & 02 & 09/22/99 & CCTV & 622 \\
\hline $\mathbf{F}$ & WLE & 05 & $09 / 22 / 99$ & CCTV & 622 \\
\hline $\mathbf{F}$ & WLE & 06 & $09 / 22 / 99$ & CCTV & 622 \\
\hline H & WLE & 02 & 04/13/99 & CCTV & 583 \\
\hline
\end{tabular}

\section{REMARKS}

Inspection revealed that structural condition had not changed. Seal materlal from joints between the cover plates continued to fall from the joints.

Inspection revealed that structural condition had not changed. Seal material from joints between the cover plates continued to fall from the joints. The cracked concrete cover remained above transfer lines. Condensate was present on the concrete cover plates and transfer lines.

Inspection revealed that structural condition had not changed.

Inspection revealed that structural condition had not changed. Molsture was observed on the bottom of cell covers, transfer lines, encasement walls, and floor. Stains and marks on encasement walls were caused by water inleakage, which appears to be minimal. Some cracking of grout material where pipes passed through the wall was observed.

Inspectlon revealed that structural condition had not changed. Molsture was observed on the bottom of cell covers, transfer lines, and floor. There is an accumulation of mud and joint waterproofing debris on the floor and on transfer lines. Stains and marks on encasement walls were caused by water inleakage, which appears to be minimal.

Inspection revealed that structural condition had not changed. Moisture was observed on the bottom of cell covers, transfer lines, and floor. There is an accumulation of mud and joint waterproofing debris on the floor and on transfer lines. Stains and marks on encasement walls were caused by water inleakage, which appears to be minimal. Small stalactites were observed hanging from the celling.

Inspection revealed that structural condition had not changed. Molsture was observed on the bottom of cell covers and floor. Stalns and marks on encasement walls were caused by water inleakage, which appears to be minimal. Small stalactites were observed hanging from the ceiling. 
TANK OR ACCESS OPENING

AREA ANCILLARY

H

WPH

(A OR I)

\section{DA1}

03/19/99

METHOD

FILE I.D. \#

HELIUM HE-99-004

H

WPH

03/23/99

HELIUM

HE-99-005

H

WPH
$06 / 03 / 99$

\section{REMARKS}

Hellum tracer test was performed on the chromated cooling water supply header from the West Pump House to Tanks 29-32. The test was inconclusive.

Helium tracer test was performed on the chromated cooling water supply header from the West Pump House to Tanks 29-32. The test revealed a leaksite located north of Tank 30 for excavation and repair.

Helium tracer test was performed on the chromated cooling water supply header from the West Pump House to Tanks 29-32. The test revealed a leaksite located north of Tank 30. 
This page intentionally left blank. 